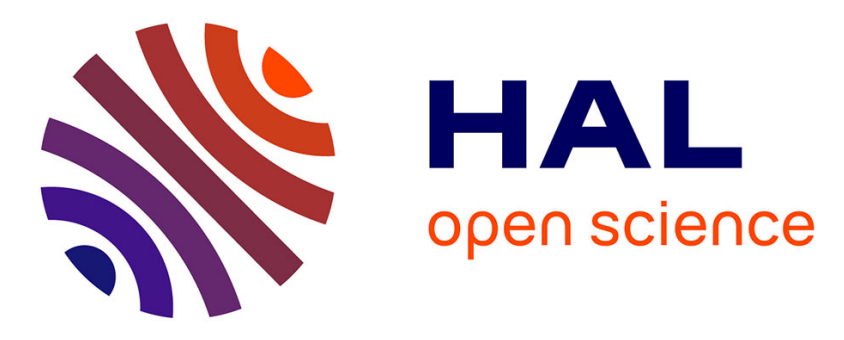

\title{
Visible-Light-Mediated Z-Stereoselective Monoalkylation of $\beta, \beta$-Dichlorostyrenes by Photoredox/Nickel Dual Catalysis
}

Mehdi Abdellaoui, Alexandre Millanvois, Etienne Levernier, Cyril Ollivier, Louis Fensterbank

\section{To cite this version:}

Mehdi Abdellaoui, Alexandre Millanvois, Etienne Levernier, Cyril Ollivier, Louis Fensterbank. VisibleLight-Mediated Z-Stereoselective Monoalkylation of $\beta, \beta$-Dichlorostyrenes by Photoredox/Nickel Dual Catalysis. SYNLETT, 2021, 32 (15), pp.1513-1518. 10.1055/a-1374-9384 . hal-03428943

\section{HAL Id: hal-03428943 https://hal.science/hal-03428943}

Submitted on 15 Nov 2021

HAL is a multi-disciplinary open access archive for the deposit and dissemination of scientific research documents, whether they are published or not. The documents may come from teaching and research institutions in France or abroad, or from public or private research centers.
L'archive ouverte pluridisciplinaire HAL, est destinée au dépôt et à la diffusion de documents scientifiques de niveau recherche, publiés ou non, émanant des établissements d'enseignement et de recherche français ou étrangers, des laboratoires publics ou privés. 


\section{Synlett Thieme}

\section{Visible-light mediated (Z)-stereoselective mono-alkylation of $\beta, \beta$-dichlorostyrenes by photoredox/Nickel dual catalysis}

\begin{tabular}{|c|c|}
\hline Journal: & SYNLETT \\
\hline Manuscript ID & Draft \\
\hline Manuscript Type: & Cluster \\
\hline $\begin{array}{r}\text { Date Submitted by the } \\
\text { Author: }\end{array}$ & $\mathrm{n} / \mathrm{a}$ \\
\hline Complete List of Authors: & $\begin{array}{l}\text { Abdellaoui, Mehdi; Sorbonne Université, Institut Parisien de Chimie } \\
\text { Moléculaire } \\
\text { Millanvois, Alexandre; Sorbonne Université, Institut Parisien de Chimie } \\
\text { Moléculaire } \\
\text { Levernier, Etienne; Sorbonne Université, Institut Parisien de Chimie } \\
\text { Moléculaire } \\
\text { Ollivier, Cyril; Sorbonne Université, Institut Parisien de Chimie } \\
\text { Moléculaire } \\
\text { Fensterbank, Louis; Sorbonne Université, UPMC Paris 06, Institut } \\
\text { Parisien de Chimie Moléculaire UMR } 8232\end{array}$ \\
\hline Keywords: & $\begin{array}{l}\text { radicals, cross-coupling, dual catalysis, dichlorostyrenes, nickel, } \\
\text { counterion, alkylation }\end{array}$ \\
\hline Abstract: & $\begin{array}{l}\text { Metal-catalyzed alkylation of } 1,1 \text {-dihalovinyl moiety commonly suffers } \\
\text { from both a lack of stereoselectivity and the overreaction leading to the } \\
\text { dialkylation product. The methodology described herein features a new } \\
\text { pathway to alkylate stereoselectively } \beta, \beta \text {-dichloro-styryl substrates to } \\
\text { provide the ( } Z \text { )-trisubstituted olefin only with fair to good yields. This } \\
\text { cross-coupling reaction bears on the smooth and photo-induced } \\
\text { formation of a C-centered radical that engages in a nickel-catalyzed } \\
\text { organometallic cycle to form the key Csp2-Csp3 bond. }\end{array}$ \\
\hline
\end{tabular}

\section{SCHOLARONE" Manuscripts}




\section{Visible-light mediated (Z)-stereoselective mono- alkylation of $\beta, \beta$-dichlorostyrenes by photoredox/Nickel dual catalysis}

\author{
Mehdi Abdellaoui ${ }^{\mathrm{a}}$ \\ Alexandre Millanvois ${ }^{a}$ \\ Etienne Levernier \\ Cyril Ollivier*a \\ Louis Fensterbank*a \\ a Institut Parisien de Chimie Moléculaire, Sorbonne Université, \\ UMR CNRS 8232, 4 Place Jussieu, Paris Cedex 05, France \\ cyril.ollivier@sorbonne-universite.fr; \\ louis.fensterbank@sorbonne-universite.fr
}

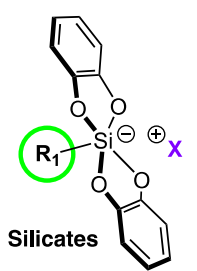

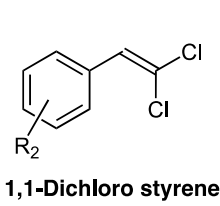

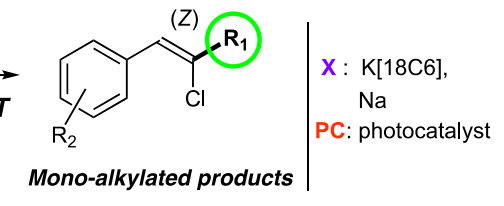

\begin{abstract}
Received:
Published online:

DOI:

Abstract Metal-catalyzed alkylation of 1,1-dihalovinyl moiety commonly suffers from both a lack of stereoselectivity and the overreaction leading to the dialkylation product. The methodology described herein features a new pathway to alkylate stereoselectively $\beta, \beta$-dichloro-styryl substrates to provide the (Z)-trisubstituted olefin only with fair to good yields. This crosscoupling reaction bears on the smooth and photo-induced formation of a Ccentered radical that engages in a nickel-catalyzed organometallic cycle to form the key $\mathrm{C}_{\mathrm{sp2} 2}-\mathrm{C}_{\mathrm{sp} 3}$ bond.
\end{abstract}

Key words Cross-coupling, stereoselective alkylation, radical, dichlorostyrenes, bis(catecholato)silicates, dual catalysis, counterion, nickel

The substitution of the carbon-chlorine bond of $\beta, \beta$ dichlorostyryl derivatives ${ }^{1,2}$ was firstly approached by Minato and Tamao ${ }^{3,4}$ who developed a palladium-catalyzed arylation that advantageously provided the (Z)-mono-arylated product (Scheme 1, eq. a). Later, Negishi and co-workers developed a palladium-catalyzed alkynylation ${ }^{5,6}$ employing zinc acetylides as nucleophilic partners to afford the (Z)-mono-substituted product with high yields and stereoselectively (Scheme 1, eq. b) However, the formation of the side di-alkynylated product remains the main weakness of this methodology. Concerning the alkylation attempts of $\beta, \beta$-dichlorostyryl substrates, they also suffered from overreaction and the disubstituted product were often observed.7,8 An alternative was considered by Figadère and Alami and consisted in the iron-catalyzed version of the Kumada cross-coupling but the formation of the dialkylated compound remained competitive (Scheme 1, eq. c). ${ }^{9}$ It was not until the work of Roulland and co-workers ${ }^{10}$ that a promising answer to the problem of a stereoselective mono-alkylation was provided. Indeed, Roulland designed a Suzuki-type reaction with 9-BBN alkyl boranes that relies on the use of a bidentate phosphine ligand for palladium with a large bite angle to achieve the mono alkylation in a high stereo-selectivity and excellent yields. However, once again, they observed traces of the $(E)$ stereoisomer and/or of the dialkylated side product, that proved difficult to separate (Scheme 1, eq. d).

In contrast, to the best of our knowledge, nickel-catalyzed monoalkylation of such electrophiles has not yet been reported in the literature. Indeed, the closest example was the enantioselective alkylation of $(Z)$ - $\beta$-bromo-styryl derivatives developed by Reisman ${ }^{11}$ to afford the mono-alkylated (Z)trisubstituted alkene with retention of the stereochemistry of the double bond. However, this methodology, did not involve the substitution of dihalogenated styryl derivatives.

a) Minato \& Tamao, 1987: arylation of dichlorostyrenes

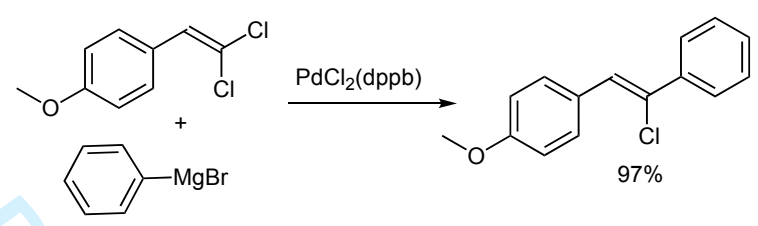

b) Negishi, 2004: alkynylation of dichlorostyrenes

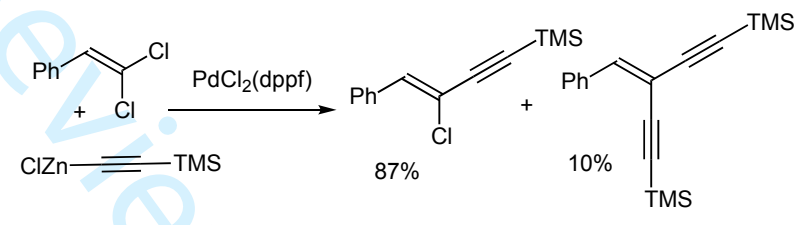

c) Figadère \& Alami, 2004; Fe-catalyzed alkylation of dichlorostyrenes

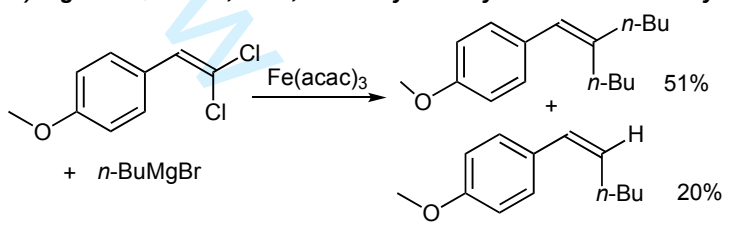

d) Roulland, 2007: alkylation of dichlorostyrenes with alkyl boranes

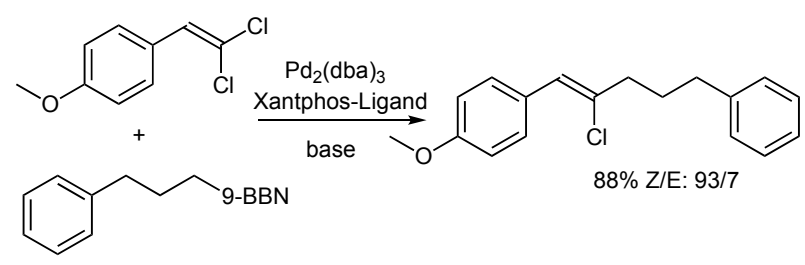

e) This work:

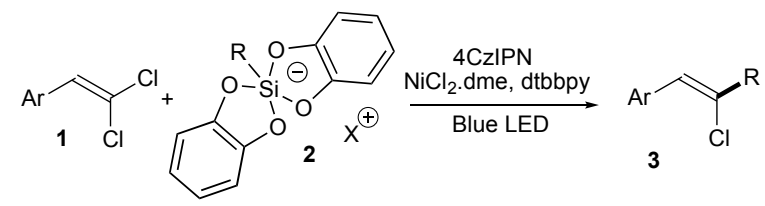

Scheme 1 Literature on metal-catalyzed arylation, alkynylation and alkylation of $\beta, \beta$-dichloro-styrenes 
Considering those elements and based on our continuing interest in photoredox catalysis ${ }^{12-15}$ and in photoredox/Ni dual catalysis, ${ }^{16-20}$ we considered involving bis(catecholato)silicates in a photoredox/Ni catalyzed vinylation reaction. ${ }^{21}$ Indeed, thanks to their low oxidation potential (between 0.3 and $0.9 \mathrm{~V}$ vs SCE) bis(catecholato)silicates are known as efficient radical precursors. ${ }^{22}$ Their uses in dual catalysis were investigated by our group ${ }^{22,23}$ and the group of Molander for the alkylation of aryl and alkenyl halides. ${ }^{24,25}$ To illustrate the versatility of this methodology, our group also investigated the $\mathrm{C}_{\mathrm{sp} 3}-\mathrm{C}_{\mathrm{sp} 3}$ bond formation, ${ }^{26}$ the formation of ketones through cross-coupling with acyl chlorides ${ }^{27}$ and the alkylation of alkenyl halides including one preliminary example of alkylation of $p$-methoxy $\beta, \beta$-dichloro-styrene. ${ }^{28}$ We wished to further investigate this valuable transformation and examined the reactivity of various dichlorostyryl substrates $\mathbf{1}$ towards silicates $\mathbf{2}$ to furnish cross coupling (Z)-styrylchloride products $\mathbf{3}$ (Scheme 1, eq. e). ${ }^{29}$

[18-C-6]-Potassium silicates $2 \mathbf{a}(\mathrm{R}=\mathrm{Bn}), \mathbf{2 b}\left(\mathrm{R}=-\left(\mathrm{CH}_{2}\right)_{2} \mathrm{OAc}\right)$, 2c $(\mathrm{R}=$ cyclohexyl $)$ and $\mathbf{2 d}\left(\mathrm{R}=-\mathrm{CH}_{2} \mathrm{NHPh}\right)$ were prepared as in previously described procedures. ${ }^{22,30}$ At the occasion of this study, we also introduced the previously unknown sodium silicates 2-Na since they could result in altered reactivity. Sodium salts as additives have indeed resulted in optimized reactivity in some nickel-catalyzed cross coupling reactions. ${ }^{11,31}$

Sodium silicates 2-Na were prepared as previously for potassium silicates (scheme 2). ${ }^{22}$ The desired alkoxysilane is reacted with catechol (2 equiv.) and with 1 equiv. of sodium methoxide in methanol. 15-Crown-5 (1 equiv.) can also be added in the reaction mixture to provide sodium silicates 2 '. Gram quantities of 2a-Na (55\% yield), 2b-Na (64\%) and 2c-Na (55\%) were obtained. Similarly, 15-C-5 chelated sodium silicates 2a' was isolated in $45 \%$ yield. All these sodium silicates can be kept several months without degradation if stored under air and moisture free conditions.

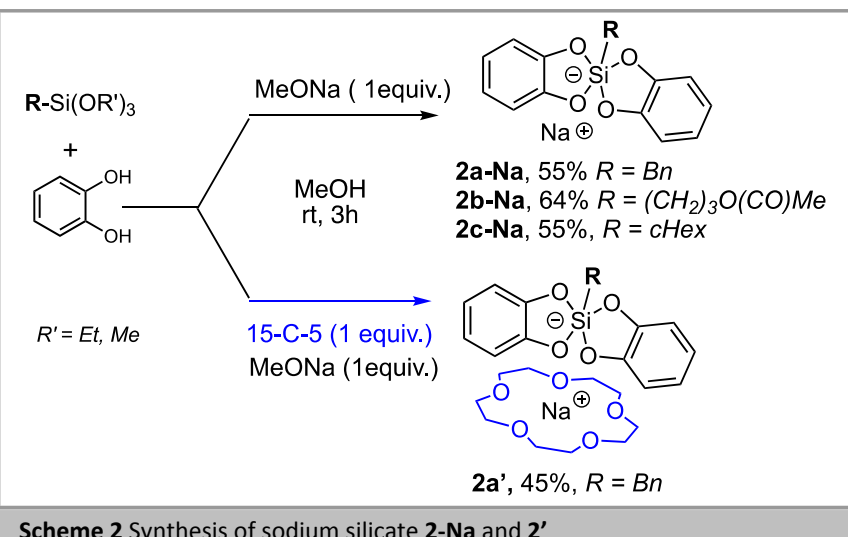

Suitable crystals of the sodium bis(catecholato)benzyl silicate 2a-Na were obtained by vapor diffusion using an acetone/diethyl ether mixture. $\left[\mathrm{C}_{22} \mathrm{H}_{21} \mathrm{NaO}_{5} \mathrm{Si}\right]$ crystallized in a tetragonal crystal system with $a=19.0046(7) \AA ̊ n, b=19.0046(7)$ $\AA, c=11.5788(5) \AA, \alpha, \beta, \gamma=90^{\circ}(\mathrm{Z}=8){ }^{32}$ Sodium ions are coordinated to one oxygen atom of four catechol ligands and one acetone molecule completes the coordination sphere. The $\mathrm{O}_{1-5}$ $\mathrm{Na}_{1}$ bond lengths are spanning from 2.288(3) $\AA$ to 2.355(2) $\AA$. Finally, an intramolecular $\pi$-cation interaction between the centroid of the benzyl and $\mathrm{Na}_{1}$ can be observed with a distance of $3.2712(9) \AA$.

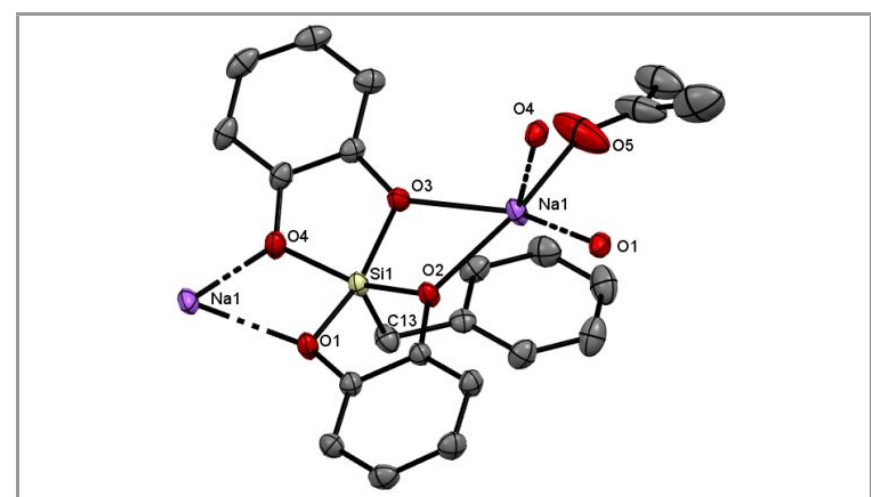

Figure $\mathbf{1} \mathrm{X}$-ray crystal structure of $\mathbf{2 a}-\mathbf{N a}$, thermal ellipsoids are drawn at $50 \%$ probability level. Hydrogen atoms are omitted for clarity. Dashed lines denote bonds between neighbouring silicates.

The Si-coordination of 2a-Na can be described as a slightly distorted square pyramid (SP) structure with the benzyl group occupying the apical site $\left(\mathrm{Si}-\mathrm{C}_{13}\right.$ bond length $\left.=1.879(2) \AA\right)$. The four basal positions are occupied by the two oxygen atoms of two catechol ligands. We can notice that $\mathrm{Si}$ atom is located just a little above the plane defined by these fourth atoms (distance Siplane centroid $=0.4517(6) \AA$ ). For $\mathbf{2 a - N a}$, the dihedral angle method permits to calculate a displacement of $89.3 \%$ (TBP $\rightarrow$ SP, TBP: trigonal bipyramidal,). ${ }^{33}$ This is also underlined by the close values of all the 4 basal bond Si-O distances from 1.735(2) to 1.759 (2) Å. Compared to an idealized SP with four angles of $86^{\circ}$, a slight distortion is observed with an angle deviations from $-2.5^{\circ}$ to $2.1^{\circ}$. Interestingly, 2a-Na forms a polymeric assembly along the $c$-axis that originates from multiple interactions between $\mathrm{Na}$ and oxygen atoms of the catechols of two silicates (see supporting information). Sodium cyclohexyl silicate 2c-Na also crystallized and a XRD structure analysis was obtained ${ }^{34}$ and proved to be very similar to the corresponding potassium one.22

Finally, oxidation potentials of sodium silicates were determined by cyclic voltammetry and proved consistent with the low values we already observed for the potassium ones ${ }^{22}$ ie $\mathrm{E}_{\mathrm{ox}}=+0.77 \mathrm{~V}$ vs SCE for $\mathbf{2} \mathbf{a}-\mathbf{N a},+0.88 \mathrm{~V}$ for $\mathbf{2} \mathbf{b}-\mathbf{N a}$ and $+0.81 \mathrm{~V}$ for 2c-Na.

All $\beta, \beta$-dichloro-styrenes $\mathbf{1}$ were synthesized by a common Corey-Fuchs-Ramirez olefination from the corresponding aldehydes $^{35}$ and were obtained with good yields. For our catalytic system, we considered the same as in our previous studies, ${ }^{28}$ namely nickel(II).dme in the presence of 2,6-di-tertbutyl bipyridine as catalytic system and 1,2,3,5tetrakis(carbazol-9-yl)-4,6-dicyanobenzene $\quad(4 \mathrm{CzIPN})^{36}$ as photocatalyst. 4CzIPN is endowed with a very high reduction potential after photoexcitation $(+1.59 \mathrm{~V} \text {. vs SCE })^{37}$ and a longlived excited state $(5.1 \mu \mathrm{s})$ which enables the efficient oxidation of the silicate $\left(E_{o x}<0,9 \mathrm{~V}\right.$. vs SCE) to afford the corresponding Ccentered radical.

We first concentrated on the cross coupling of 1vinylnaphtalene derivatives $\mathbf{1 a}$ as electrophiles with benzyl silicates 2a (see Table 1). We began our investigation by delineating the range of dihalogeno-styrenes that could handle this approach (Table 1, entries 1-3). The difluorinated reagent 1a-F did not react despite the presence of silicon on the radical precursor likely to establish a strong interaction with a fluoride. In contrast, the dibrominated reagent $\mathbf{1 a - B r}$ led in our 
conditions to a complex mixture in which only a marginal amount of mono was detected. Interestingly, only the presumably less reactive dichlorinated substrate 1a positively reacted in this dual catalysis reaction (44\% of adduct 3aa) and was then chosen as model substrate for the optimization of the reaction conditions. To our delight, the alkylation occurred selectively without any formation of side products such as the dialkylated product or the (E)-stereoisomer. The (Z)stereochemistry of 3aa was assigned by analogy with subsequent findings (vide infra).

Table 1 Optimization of the cross-coupling reaction

\begin{tabular}{|c|c|c|c|c|c|}
\hline Entry & $\begin{array}{l}\text { React. } \\
\text { time (h) }\end{array}$ & $x$ & [Si] counter ion & $\begin{array}{l}\text { Silicate } \\
\text { equiv. }\end{array}$ & $\begin{array}{c}\text { Yield } \\
\text { (\%), 3aa }\end{array}$ \\
\hline 1 & 48 & F, 1a-F & $\mathrm{K}[18-\mathrm{C}-6], \mathbf{2 a}$ & 1.5 & $N R^{b}$ \\
\hline 2 & 48 & $\mathrm{Br}, \mathbf{1 a}-\mathrm{Br}$ & $K[18-C-6], \mathbf{2 a}$ & 1.5 & Mixture \\
\hline 3 & 48 & $\mathrm{Cl}, \mathbf{1 a}$ & $K[18-C-6], 2 a$ & 1.5 & 44 \\
\hline 4 & 48 & $\mathrm{Cl}, \mathbf{1 a}$ & K, 2a-K & 1.5 & 39 \\
\hline 5 & 48 & $\mathrm{Cl}, \mathbf{1 a}$ & $\mathrm{Na}[15-\mathrm{C}-5], \mathbf{2} \mathrm{a}^{\prime}$ & 1.5 & 39 \\
\hline 6 & 48 & $\mathrm{Cl}, \mathbf{1 a}$ & $\mathrm{Na}, 2 \mathrm{a}-\mathrm{Na}$ & 1.5 & 42 \\
\hline 7 & 48 & $\mathrm{Cl}, \mathbf{1} \mathbf{a}$ & $K[18-C-6], 2 a$ & 3 & 47 \\
\hline $8^{c}$ & 48 & $\mathrm{Cl}, \mathbf{1 a}$ & $K[18-C-6], 2 a$ & 3 & 51 \\
\hline 9 & 72 & $\mathrm{Cl}, \mathbf{1} \mathbf{a}$ & $\mathrm{K}[18-\mathrm{C}-6], \mathbf{2 a}$ & 1.5 & 50 \\
\hline 10 & 72 & $\mathrm{Cl}, \mathbf{1 a}$ & $\mathrm{K}[18-C-6], \mathbf{2 a}$ & 3 & 70 \\
\hline $11^{d}$ & 48 & $\mathrm{Cl}, \mathbf{1 a}$ & $\mathrm{K}[18-\mathrm{C}-6], \mathbf{2 a}$ & 1.5 & 0 \\
\hline
\end{tabular}

aNMR Yield determined using 1,3,5-trimethoxybenzene as internal standard; ${ }^{\mathrm{b}} \mathrm{NR}$ : no reaction detected; ${ }^{c}$ Variation of the concentration (from $0.1 \mathrm{M}$ to $0.2 \mathrm{M}$ ); ${ }^{d}$ Reaction performed without nickel catalyst.

We then examined the effect of the cation in this reaction. No improvement of yield was observed from free potassium silicate $\mathbf{2 a - K}$ (39\% of 3a, entry 4), sodium silicates with 15-C-5 (2a', $39 \%$, entry 5) or without 15-C-5 (2a-Na, 42\%, entry 6). Nevertheless, the fact that the plain sodium silicate $\mathbf{2 a - N a}$ could be engaged successfully opened interesting perspectives. Focusing on silicate $\mathbf{2 a}$, we then investigated other possibilities to increase the yield of 3aa (Table 1). While doubling the loading in silicate (entry 7) or its concentration (entry 8) did not have a significant impact on the yield, a longer reaction time $(72$ h) with double amount of 2a provided the best yield of $3 \mathbf{a}$ (70\%, entry 10). We also checked that nickel catalysis was necessary for this transformation: no radical addition - $\beta$-elimination of a chlorine radical takes place ${ }^{22}$ to deliver 3aa (entry 11)

Based on all the results from Table 1, the standard conditions ( $48 \mathrm{~h}$ and 1.5 equivalents of silicate) appear to be a good compromise in terms of reaction time and cost to reach a decent yield in this cross-coupling reaction. Subsequently, we engaged in those conditions various [18-C-6]-potassium and sodium silicates $\mathbf{2}$ and $\mathbf{2}$-Na with $\beta, \beta$-dichlorostyrenes $\mathbf{1}$ in the $\mathrm{Ni} / 4 \mathrm{CzIPN}$ dual catalysis conditions to explore the scope of this reactivity (Scheme 2 ).

The results of Table 2 illustrate a certain versatility of this crosscoupling reaction between the gem-dichloro-styryl precursors 1 and the silicates 2 . Indeed, the reaction occurs with an alkylsilicate (primary and secondary), a benzylic one and even the $\alpha$ methyl-anilino-silicate with various dichloro-styrenes $\mathbf{1}$ and provides previously unknown coupling products with fair to good yields. In some cases, the use of the sodium silicates 2-Na compared to the potassium ones 2 proved more rewarding in terms of yields for coupling products $\mathbf{3}$ (products $\mathbf{3} \mathbf{a b}$ and $\mathbf{3 d c}$ ). The coupling does not depend on the electron-withdrawing or electron-donating character of the substituent of the dichlorostyrene. Indeed, substrates that own a methoxy group or a trifluoromethyl group in para position react similarly with the primary alkyl acetoxypropyl radical (2b) or the more nucleophilic $\alpha$-methyl-aniline one (2d) (Table 2).

Table 2 Reaction of gem-dichlorostyrenes 1 with various silicates $\mathbf{2}$ (isolated yieds)

we investigated the possibility of the post-functionalization of our alkylated adducts by using our methodology.

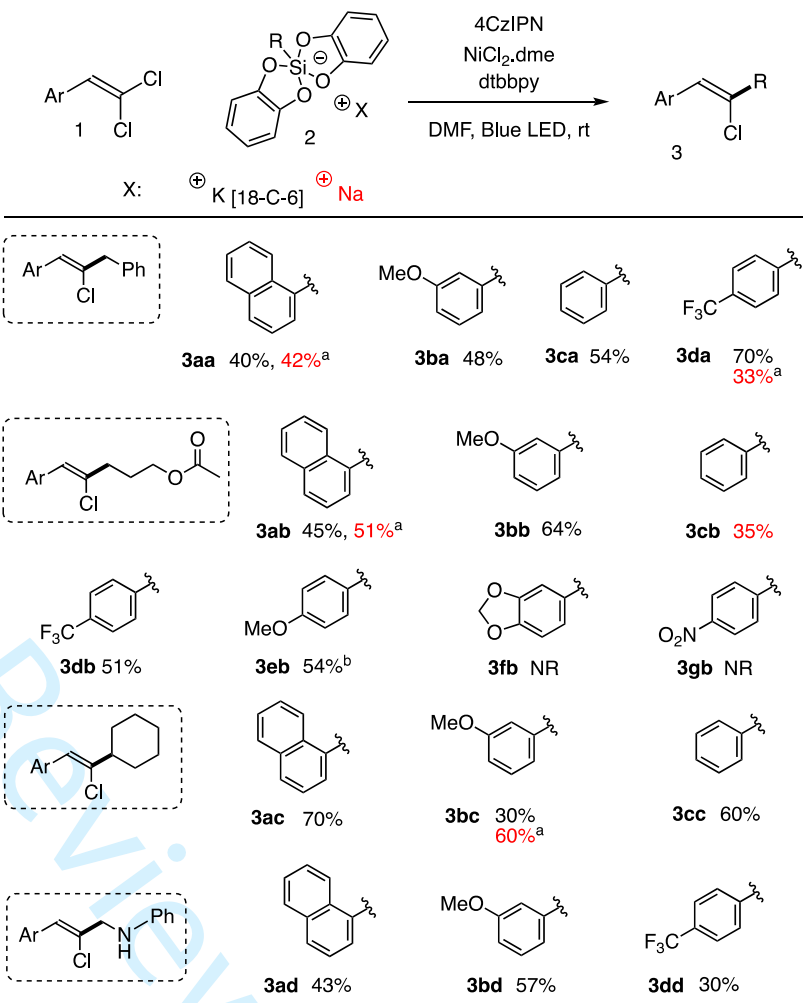

NR: no reaction detected, we only recovered starting material; a NMR yield determined using 1,3,5-trimethoxybenzene as internal standard; 'b See also ref. 28.

Of note, the more touchy precursors, piperonal and nitro substrates failed to give any adducts ( $\mathbf{3} \mathbf{f b}$ and $\mathbf{3 g b}$ ) and it is also important to specify that only the $Z$ isomer, as determined by NOESY experiments, of each adduct $\mathbf{3}$ was isolated and that no dialkylation product was observed. In the reactions of amino silicate $\mathbf{2 d}$, some $(Z)$-chlorostyrene was formed as side product in $15-20 \%$ yield that was highly suggestive of a protodenickelation based on the proposed mechanism of Scheme 3.

Because, we know that nickel is necessary in these reactions to obtain products 3 and based on the literature mechanism proposals of related $\mathrm{Ni} /$ photoredox dual catalysis reactions, ${ }^{18-}$ 20,38 it appears reasonable to invoke the trapping by nickel of a $\mathrm{C}$-centered radical originating from the photo-induced oxidation of the silicates 2 . The nickel intermediate that would be involved is the nickel(II) complex I that originates from the oxidative addition into the a $\mathrm{C}-\mathrm{Cl}$ bond of the substrates $\mathbf{1}$ (Scheme 3). The observed (Z)-selectivity might be ascribed to the presence of the bidentate ligand on nickel that would generate a significant steric hindrance around the metallic 
center and that possibly orients the oxidative addition on the more accessible $\mathrm{C}-\mathrm{Cl}$ bond, with no aryl group in syn. Even though the effect of the bulkiness around the metallic center seems clear, the insensitivity of the coupling to the substituent on the aryl moiety might appear strange but is reminiscent of previous findings in arylative couplings. ${ }^{23,24}$ This would be consistent with a radical addition on nickel(II) that is rather insensitive to electronic effects. ${ }^{39-42}$ The resulting nickel(III) complex II then undergoes reductive elimination to provide products 3 and a nickel(I) salt that would be reduced by the photoredox cycle to $\mathrm{Ni}(0)$.

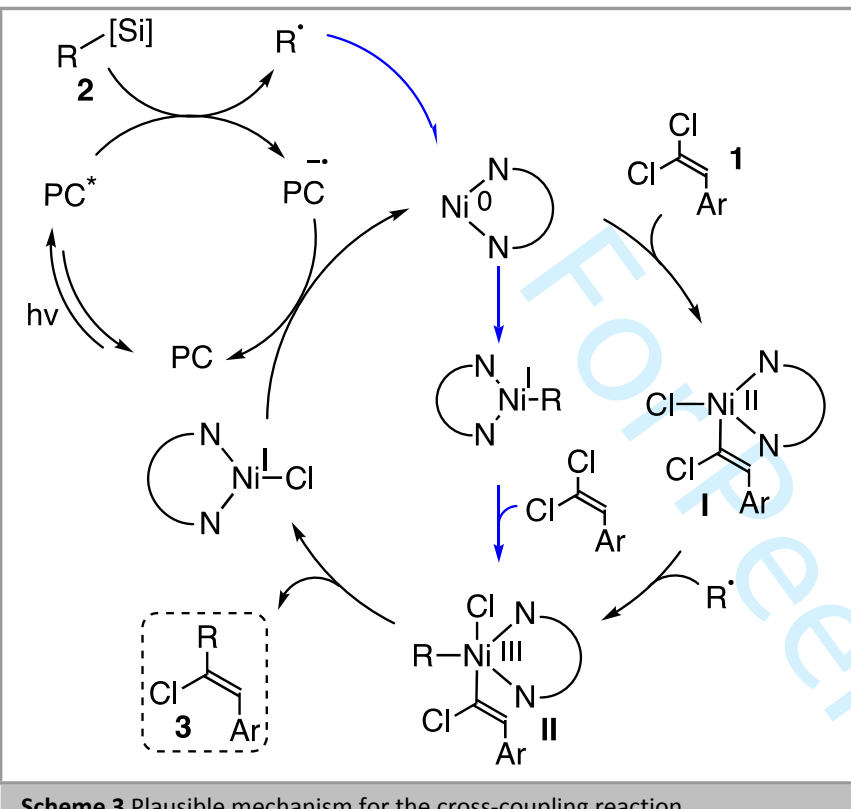

Based on the clean but inefficient conversion of some of these reactions, we also wished to explore other conditions to run them. Notably we used an in-house flow ${ }^{43,44}$ setting (see SI for details) in order to reduce the reaction times. We tested silicate 2c and naphthyl electrophile 1a as a model reaction based on its efficiency in batch after $48 \mathrm{~h}$ of irradiation $(70 \%$ of 3ac, Table 2). Interestingly, within a residence time of $50 \mathrm{~min}$, we reached $32 \%$ yield in 3 ac and $50 \%$ within $90 \mathrm{~min}$. Therefore, the flow conditions open promising perspectives for this methodology.

Finally, we investigated the possibility of the postfunctionalization of the alkylated adducts $\mathbf{3}$ by using our methodology. We engaged different mono-alkylated products 3 with silicates $\mathbf{2}$ (3bb with benzyl silicate and $\mathbf{3 b d}$ with acetoxypropyl silicate) and we only recovered the starting material after 2 days of irradiation. All in all, this absence of reactivity confirms that our methodology is inoperative to achieve the substitution of the two C-Cl bonds. Nevertheless, Roulland's and Tamao's works showed that the post functionalization of the mono-substituted product was effective by engaging them in their palladium-catalyzed alkylation or arylation sequences. ${ }^{2,3}$

To conclude, we have developed an innovative way to alkylate gem-dichloro-styrenes with fair to good yields. Contrary to most of the previous methodologies employing palladium catalysts, this cross-coupling reaction advantageously combines the earthabundant nickel metal with a cheap organic dye to achieve smoothly the substitution at room temperature (where all the previous methods mentioned are performed under reflux). Furthermore, the main advantages of this reaction are its total $(Z)$-stereoselectivity and the absence of overreaction to widen the scope of this methodology. Otherwise, one of the aims of the study was the approach of the silicate's counterion and its effect on the photoredox catalysis. The second interest of this study is the introduction of sodium silicates $\mathbf{2 - N a}$ improves atom economy compared to the [18-C-6] chelated potassic silicates analogs 2. If this work provided interesting and promising insights, the influence of the counterion remains non exhaustive and will be pursued by our group.

\section{Funding Information}

The authors thank ANR-17-CE07-0018 HyperSilight (PhD grant to EL), CNRS and Sorbonne Université for financial support.

\section{Acknowledgment}

We are grateful to J. Forté, G. Gontard and Lise-Marie Chamoreau for Xray diffraction analyses and helpful discussions.

\section{Supporting Information}

Is there Supporting Information to be published? Click here, then the arrow, and choose YES or NO.

\section{Primary Data}

No

\section{References and Notes}

(1) Chelucci, G. Chem. Rev. 2012, 112, 1344.

(2) Arthuis, M.; Lecup, A.; Roulland, E. Chem. Commun. 2010, 46, 7810.

(3) Minato, A.; Suzuki, K.; Tamao, K. A J. Am. Chem. Soc. 1987, 109, 1257.

(4) Minato, A. J. Org. Chem. 1991, 56, 4052.

(5) Shi, J.; Zeng, X.; Negishi, E. Org. Lett. 2003, 5, 1825.

(6) Negishi, E.; Shi, J.; Zeng, X. Tetrahedron 2005, 61, 9886.

(7) Andrei, D.; Wnuk, S. F. J. Org. Chem. 2006, 71, 405.

(8) Tan, Z; Negishi, E. Angew. Chem. Int. Ed. 2006, 45, 762.

(9) Dos Santos, M.; Franck, X.; Hocquemiller, R.; Figadère, B.; Peyrat, J.-F.; Provot, O.; Brion, J.-D.; Alami, M. Synlett 2004, 2004, 2697.

(10) Liron, F.; Fosse, C.; Pernolet, A.; Roulland, E. J. Org. Chem. 2007, 72, 2220.

(11) DeLano, T. J.; Reisman, S. E. ACS Catal. 2019, 9, 6751.

(12) McAtee, R. C.; McClain, E. J.; Stephenson, C. R. J.. Trends in Chemistry 2019, 1, 111.

(13) Marzo, L.; Pagire, S. K.; Reiser, O.; König, B. Angew. Chem. Int. Ed, 2018, 57, 10034.

(14) Crespi, S.; Fagnoni, M. Chem. Rev. 2020, 120, 9790.

(15) Xuan, J.; Zang, Z.-G.; Xiao, W.-J. Angew. Chem. Int. Ed., 2015, 54, 15632.

(16) Levin, M. D.; Kim, S.; Toste, F. D. ACS Cent. Sci. 2016, 2, 293.

(17) Hopkinson, M. N.; Sahoo, B.; Li, J.-L.; Glorius, F. Chem. Eur. J. 2014, 20, 3874. 
(18) Nacsa, E. D.; MacMillan, D. W. C. Org. React. 2019; pp 471-546.

(19) Skubi, K. L.; Blum, T. R.; Yoon, T. P. Chem. Rev. 2016, 116,10035

(20) Tellis, J. C.; Kelly, C. B.; Primer, D. N.; Jouffroy, M.; Patel, N. R.; Molander, G. A. Acc. Chem. Res. 2016, 49, 1429.

(21) Goddard, J.-P.; Ollivier, C.; Fensterbank, L. Acc. Chem. Res. 2016, 49, 1924.

(22) Corcé, V.; Chamoreau, L. M.; Derat, E.; Goddard, J.-P.; Ollivier, C.; Fensterbank, L. Angew. Chem. Int. Ed. 2015, 54,11414 .

(23) Lévêque, C.; Chenneberg, L.; Corcé, V.; Goddard, J.-P.; Ollivier, C.; Fensterbank, L. Org. Chem. Front. 2016, 3, 462.

(24) Jouffroy, M.; Primer, D. N.; Molander, G. A. J. Am. Chem. Soc. 2016, 138, 475.

(25) Patel, N. R.; Kelly, C. B.; Jouffroy, M.; Molander, G. A. Org. Lett. 2016, 18, 764.

(26) Lévêque, C.; Corcé, V.; Chenneberg, L.; Ollivier, C.; Fensterbank, L. Eur. J. Org. Chem. 2017, 2017, 2118.

(27) Levernier, E.; Corcé, V.; Rakotoarison, L.-M.; Smith, A.; Zhang, M.; Ognier, S.; Tatoulian, M.; Ollivier, C.; Fensterbank, L. Org. Chem. Front. 2019, 6, 1378.

(28) Lévêque, C.; Chenneberg, L.; Corcé, V.; Ollivier, C.; Fensterbank, L. Chem. Commun. 2016, 52, 9877.

(29) For a recent access to vinylchlorides, see: Adak, T.; Hoffmann, M.; Witzel, S.; Rudolph, M.; Dreuw, A.; Hashmi, A. S. K. Chem. Eur. J. 2020, 26, 15573.
(30) Corcé, V., Lévêque, C., Ollivier, C., Fensterbank, L. in Science of Synthesis: Photocatalysis in Organic Synthesis 2019, pp. 427-466, Ed. König, B. Thieme Stuttgart.

(31) Prinsell, M. R.; Everson, D. A.; Weix, D. J. Chem. Commun. 2010, 46, 573.

(32) CCDC for 2a-Na: 2048159.

(33) Holmes, R. R.; Deiters, J. A. Phosphorus, Sulfur and Silicon 1995, 98, 105.

(34) CCDC for 2c-Na: 2050302.

(35) Burton, G.; Elder, J. S.; Fell, S. C. M.; Stachulski, A. V. Tetrahedron Letters 1988, 29, 3003.

(36) Shang, T.-Y.; Lu, L.-H.; Cao, Z.; Liu, Y.; He, W.-M.; Yu, B. Chem. Commun. 2019, 55, 5408.

(37) Le Vaillant, F.; Garreau, M.; Nicolai, S.; Gryn'ova, G.; Corminboeuf, C.; Waser, J. Chem. Sci. 2018, 9, 5883.

(38) Tasker, S. Z.; Jamison, T. F. J. Am. Chem. Soc. 2015, 137, 9531.

(39) Durandetti, M.; Nédélec, J.-Y.; Périchon, J. J. Org. Chem. 1996, 61, 1748 .

(40) Weix, D. J. Acc. Chem. Res. 2015, 48, 1767.

(41) Richmond, E.; Moran, J. Synthesis 2018, 50, 499.

(42) a) Lévêque, C.; Ollivier, C.; Fensterbank, L. in Nickel Catalysis in Organic Synthesis Edt Ogoshi, S. Wiley 2020, pp 151-181; b) Goldfogel, M. J.; Huang, L.; Weix, D. J. ibid. pp 183-222.

(43) Cambié, D.; Bottecchia, C.; Straathof, N. J. W.; Hessel, V.; Noël, T Chem. Rev. 2016, 116, 10276.

(44) Garlets, Z. J.; Nguyen, J. D.; Stephenson, C. R. J. Isr. J. Chem. 2014, 54, 351. 


\section{Supporting Information}

\section{Visible-light mediated (Z)-stereoselective mono-alkylation of $\beta, \beta$ - dichloro-styrenes by photoredox/Nickel dual catalysis}

Mehdi Abdellaoui, Alexandre Millanvois, Etienne Levernier, Cyril Ollivier*, Louis Fensterbank*

Sorbonne Université, CNRS

Institut Parisien de Chimie Moléculaire

4 Place Jussieu, CC 229, F-75252 Paris Cedex 05, France

E-mail: cyril.ollivier@sorbonne-universite.fr, louis.fensterbank@sorbonne-universite.fr

\section{Table of content}

I. General informations S2

II. General procedures S3

III. Compound characterizations S6

IV. $\quad{ }^{1} \mathrm{H},{ }^{13} \mathrm{C},{ }^{19} \mathrm{~F}$ and ${ }^{29} \mathrm{Si}$ NMR spectra $\quad \mathrm{S} 19$

V. X-ray crystallographic details $\quad$ S47

VI. Cyclic voltammetries $\quad$ S49 


\section{General informations}

Unless otherwise noted, reactions were carried out under an argon atmosphere in oven-dried glassware. Methanol was distillated over $\mathrm{CaH}_{2}$ and DMF was dried with a PureSolv solvent purification system from Innovative Technology. Catechol was purchased from commercial source and purified by crystallization from chloroform. Reagents and chemicals were purchased from commercial sources and used as received. Infrared (IR) spectra were recorded on a Bruker Tensor 27 (ATR diamond) spectrophotometer. Melting points were determined on a melting point apparatus SMP3 (Stuart scientific). Electrochemical measurements were carried out an Origaflex (Origalys) electrochemical workstation. ${ }^{1} \mathrm{H},{ }^{13} \mathrm{C}$ and ${ }^{19} \mathrm{~F}$ NMR spectra were recorded at room temperature at 400, 100 and $376 \mathrm{MHz}$ respectively, on $400 \mathrm{MHz}$ Bruker AVANCE I spectrometer and at 300, 75 and $282 \mathrm{MHz}$ respectively, on $300 \mathrm{MHz}$ Bruker AVANCE II spectrometer. ${ }^{29} \mathrm{Si}$ NMR pectra were recorded at room temperature at $79 \mathrm{MHz}$ on $400 \mathrm{MHz}$ Bruker AVANCE I spectrometer. Chemical shifts ( $\delta$ ) are reported in ppm and coupling constants $(\mathrm{J})$ are given in Hertz $(\mathrm{Hz})$. Abbreviations used for peak multiplicity are: $\mathrm{s}$ (singlet); bs (broad singlet); $d$ (doublet); $t$ (triplet); q (quartet); quint (quintet); sept (septet); $m$ (multiplet) etc. Thin layer chromatographies (TLC) were performed on Merck silica gel $60 \mathrm{~F} 254$ and revealed with a UV lamp $(\lambda=254 \mathrm{~nm})$ and $\mathrm{KMnO}_{4}$ staining. Flash Column Chromatographies were conducted on Silica gel $60 \mathrm{M}, 0.04-0.063 \mathrm{~mm}$, from Macherey Nagel. High resolution mass spectrometries were performed on a microTOF (ESI). All the solvents used in flash chromatography (toluene, petroleum ether, pentane and $\mathrm{Et}_{2} \mathrm{O}$ ) were distillated. 


\section{General procedures}

\section{General procedure 1. Synthesis of the silicates}

\section{Synthesis of [18-crown-6] bis(catecholato)-alkylsilicate}
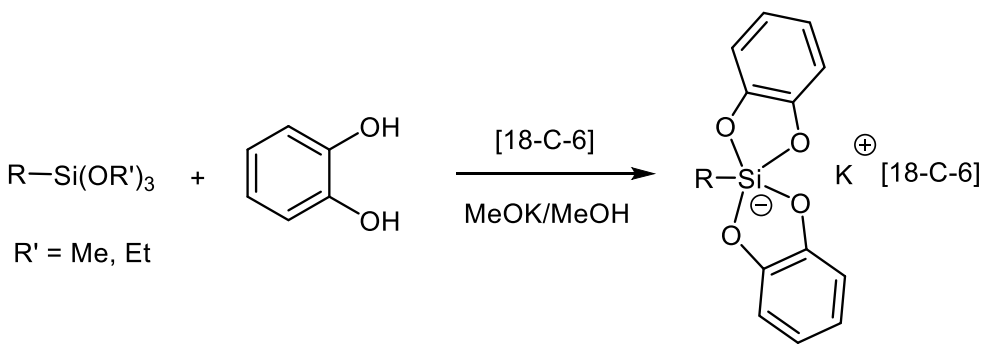

To a stirred solution of catechol (2 equiv) in dry methanol (0.25 M) was added 18-Crown-6 [18-C-6] (1 equiv). After dissolution of the crown ether, the trialkoxyorganosilane (1 equiv) was added followed by a solution of potassium methoxide in methanol (1 equiv). The reaction mixture was stirred for 3 hours and the solvent was removed under reduced pressure. The residue was dissolved in a minimum volume of acetone and diethyl ether was added until a cloudy solution was obtained (scrapping on the edge of the flask could be done to induce crystallization). The flask was placed at $-20^{\circ} \mathrm{C}$ overnight. The crystals were collected by filtration under air, washed with diethyl ether and dried under vacuum to afford [18-C-6] potassium silicate. ${ }^{1}$

\section{Synthesis of sodium or potassium bis(catecholato)-alkyl silicate}

All manipulations were performed following the conventional Schlenk techniques.

In a dry Schlenk tube under argon covered with aluminium fold was added catechol (2 equiv) and the Schlenk was purged. Degassed $\mathrm{MeOH}(0.25 \mathrm{M})$ was added followed by the alkyltriethoxysilane (1 equiv.). A solution of sodium or potassium methoxide in methanol (1 equiv) was added dropwise and the reaction was stirred 3 hours at room temperature. Solvent was removed directly on the Schlenk line and the crude was dry under high vacuum until a powder was obtained. Silicate was purified by recrystallisation as mentioned for each silicate. The crystals were collected by filtration under argon flux, washed with degassed diethyl ether and dried under vacuum to afford the desired silicate.

\section{General procedure 2. Synthesis of $\beta, \beta$-dihalostyryls}

\section{Synthesis of $\beta, \beta$-dichlorostyryl derivatives}

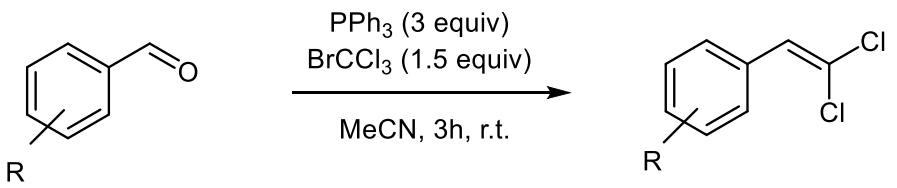

In a round-bottom-flask was added the aldehyde (1.0 equiv) in $\mathrm{MeCN}(0.125 \mathrm{M})$. The reaction mixture was cooled with an ice bath to $0^{\circ} \mathrm{C}$ and $\mathrm{BrCCl}_{3}$ (1.5 equiv) was added, followed by addition of a solution of triphenylphosphine (3.0 equiv) in a minimum amount of $\mathrm{MeCN}$. The reaction mixture was stirred at room temperature for 3 hours then the solvent was removed under reduced pressure to afford a crude residue. This residue was dissolved in dichloromethane $(0.25 \mathrm{M})$ and the organic phase was washed with water, brine and dried over $\mathrm{MgSO}_{4}$. The solvent was removed under reduced pressure and the residue purified on a pad of silica (elution with a mixture $\mathrm{Et}_{2} \mathrm{O}: n$-pent (1:9)), giving the pure material.

\footnotetext{
${ }^{1}$ Corcé, V.; Chamoreau, L. M.; Derat, E.; Goddard, J.-P.; Ollivier, C.; Fensterbank, L. Angew. Chem. Int. Ed. $2015,54,11414$.
} 


\section{Synthesis of $\beta, \beta$-dibromostyryl derivatives}<smiles>[R]c1ccc(C=O)cc1</smiles>

In a round-bottom-flask was added the aldehyde (1.0 equiv) in MeCN (0.125 M). The reaction mixture was cooled with an ice bath to $0^{\circ} \mathrm{C}$ and $\mathrm{CBr}_{4}$ (1.5 equiv) was added, followed by addition of a solution of triphenylphosphine (3.0 equiv) in a minimum amount of $\mathrm{MeCN}$. The reaction mixture was stirred at room temperature for 3 hours then the solvent was removed under reduced pressure to afford a crude residue. This residue was dissolved in dichloromethane $(0.25 \mathrm{M})$ and the organic phase was washed with water, brine and dried over $\mathrm{MgSO}_{4}$. The solvent was removed under reduced pressure and the residue purified on a pad of silica (Et ${ }_{2} \mathrm{O}: n$-pentane) , giving the pure material.

\section{Synthesis of $\beta, \beta$-difluorostyryl derivatives}

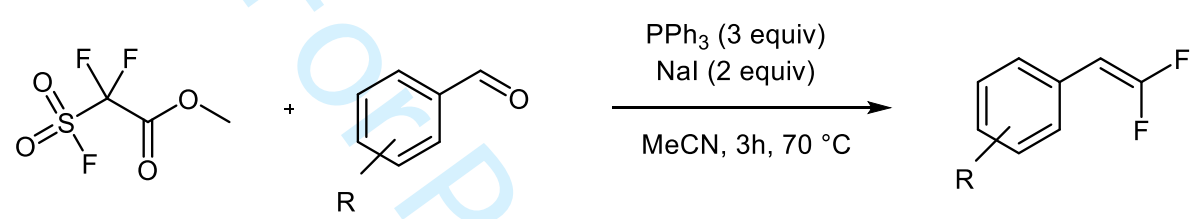

In a two-neck round-bottom-flask was added the aldehyde (1.0 equiv), Nal (2 equiv) and $\mathrm{PPh}_{3}$ (3.0 equiv) in $\mathrm{MeCN}(0.5 \mathrm{M})$. The reaction mixture was heated at $70^{\circ} \mathrm{C}$ for 30 minutes then methyl 2,2-difluoro-2(fluorosulfonyl)acetate (1.75 equiv) was added over 10 minutes. The reaction mixture was stirred at $70^{\circ} \mathrm{C}$ for 3 hours then water was added and the resulting solution was extracted with $\mathrm{Et}_{2} \mathrm{O}$ ( 3 times), dried over $\mathrm{MgSO}_{4}$, filtered and concentrated in vacuo. The obtained residue was purified by column chromatography ( $n$-pentane).

\section{General procedure 3. Photoredox/nickel cross-coupling dual catalysis with the $\beta, \beta$ - dihalogenostyryl derivative}

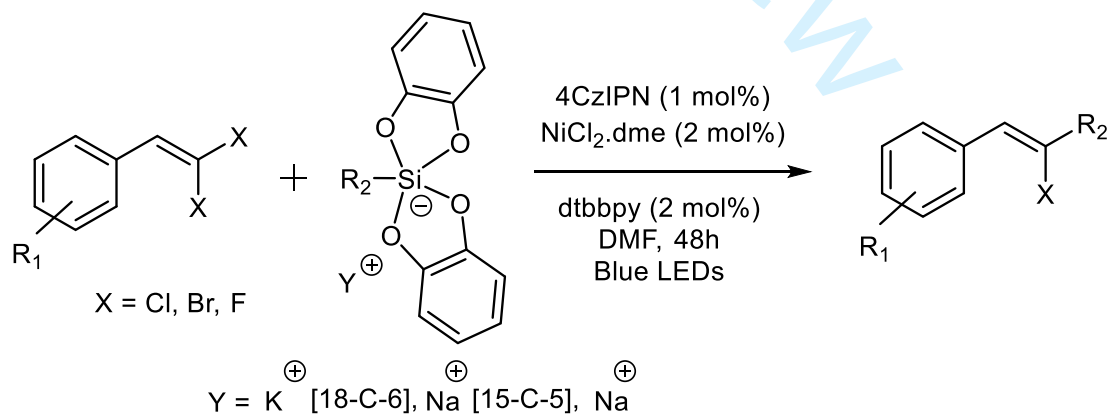

To a Schlenk tube was added the $\beta, \beta$-dihalostyryl derivative ( 1 equiv.), the appropriate silicate (1.5 equiv.), 4CzIPN (1 mol \%) and 4,4'-di-tertbutyl-2,2'-bipyridine ( $2 \mathrm{~mol} \%)$. The Schlenk tube was then charged with $\mathrm{NiCl}_{2}$.dme (2 mol \%) into a glovebox, sealed with a rubber septum, removed from the glovebox, and evacuated/purged with vacuum/argon three times. Degassed DMF $(0.1 \mathrm{M})$ was introduced (with the $\beta, \beta$ dihalostyryl derivative if it is a liquid) and the reaction mixture was irradiated with blue LEDs (477 $\mathrm{nm}$ ) for 48 hours. The reaction mixture was diluted with diethyl ether, washed with saturated $\mathrm{NaHCO}_{3}$ (2 times), brine (2 times), dried over $\mathrm{MgSO}_{4}$ and evaporated under reduced pressure. The residue was purified by flash column chromatography on silica gel to afford the cross-coupling product. 


\section{General procedure 4. Continuous flow photoredox/nickel cross-coupling dual catalysis}

A solution of 1-(2,2-dichlorovinyl)naphthalene 1 a $(0.21 \mathrm{mmol}, 47.3 \mathrm{mg})$ with potassium [18-C-6] bis(catecholato)-cyclohexylsilicate $2 \mathrm{~b}(0.32 \mathrm{mmol}, 193 \mathrm{mg}), 4 \mathrm{CzIPN}(1 \mathrm{~mol} \%, 0.002 \mathrm{mmol}, 1.73 \mathrm{mg}), 2,2^{\prime}$-ditert-butyl-bipyridine ( $2 \mathrm{~mol} \%, 0.004 \mathrm{mmol}, 1 \mathrm{mg}$ ) and $\mathrm{NiCl}_{2} . \mathrm{dme}(2 \mathrm{~mol} \%, 0.004 \mathrm{mmol}, 0.93 \mathrm{mg}$ ) prepared in glovebox in degassed DMF ( $1 \mathrm{~mL}$ ) was pumped by a syringe pump (KDScience, model KDS-100-CE) with a flow rate of $1.2 \mathrm{~mL} / \mathrm{h}$ for the experiment with a residence time of $50 \mathrm{~min}$ (Experiment in Red) and $0.67 \mathrm{~mL} / \mathrm{h}$ for a residence time of $90 \mathrm{~min}$ (Experiment in Blue). The mixture was mixed within a glass milli-mixer (LTF-MX, 0.2 $\mathrm{mL}$ at room temperature, Little Things Factory, Germany) under blue LED irradiation ( $477 \mathrm{~nm}$ ) and then flowed through a PTFE tubing (1/16" tubing, $2 \mathrm{~m}, 1 \mathrm{~mL}$ at room temperature) under blue LED irradiation ( $477 \mathrm{~nm}$ ). The mixer and the PTFE tubing were rinsed with degassed DMF prior to use. The residence time was calculated with the total reaction volume and the total flow rate. The reaction mixture was then collected, diluted with diethyl ether, washed with an aqueous saturated $\mathrm{K}_{2} \mathrm{CO}_{3}$ solution (2 times), brine (2 times), dried over $\mathrm{MgSO}_{4}$ and evaporated under reduced pressure. The crude residue was purified by flash column chromatography on silica gel to afford the product.

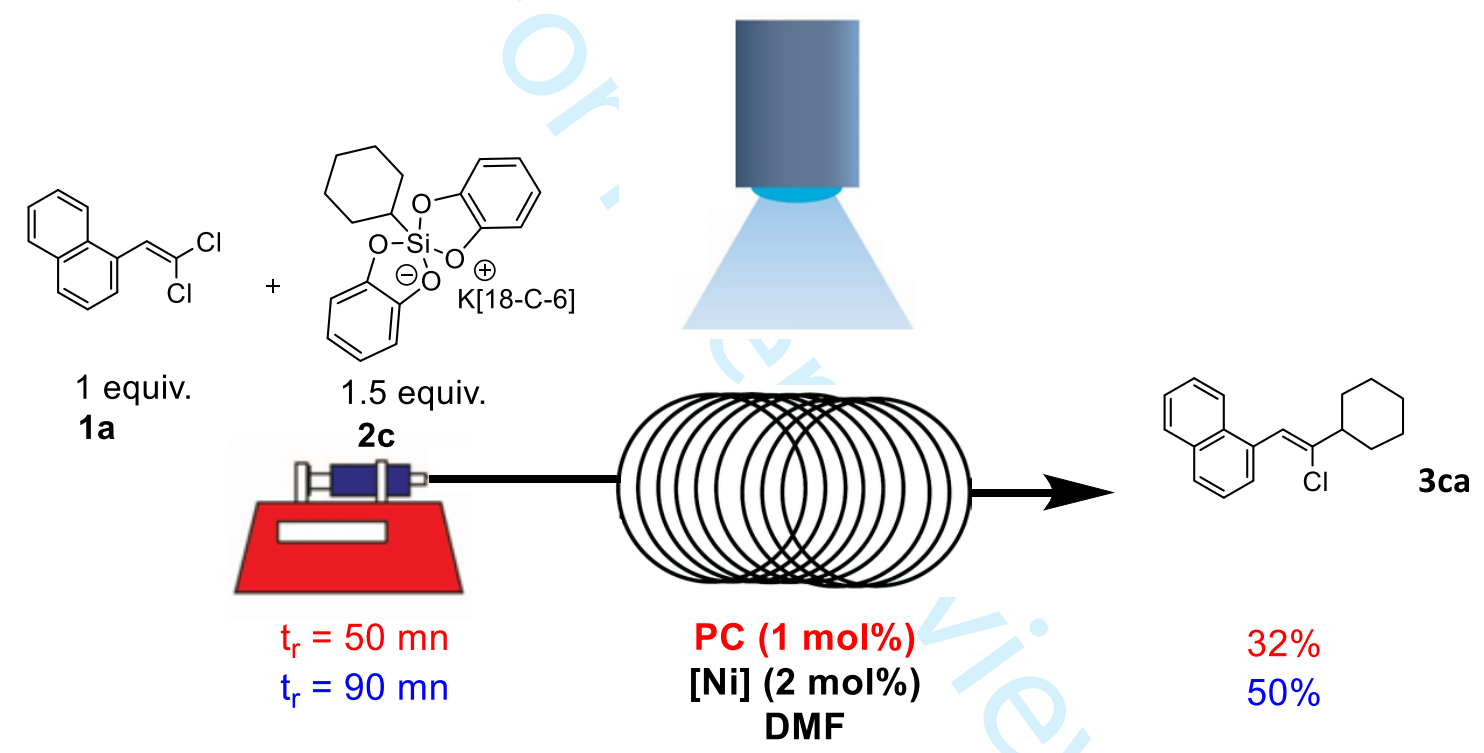




\section{Compound characterizations}

\section{Synthesis and characterisation of the silicates}

\section{Potassium [18-Crown-6] bis(catecholato)-benzylsilicate 2a}

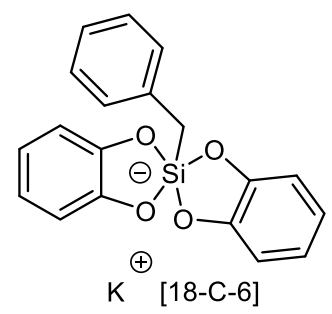

The silicate 2a was synthesized as described in General procedure 1.1. The spectroscopic data are in agreement with those reported in the literature. ${ }^{1}$

${ }^{1}$ H NMR (400 MHz, Methanol-d4): $\delta 7.09-6.75(\mathrm{~m}, 5 \mathrm{H}), 6.66-6.60(\mathrm{~m}, 4 \mathrm{H}), 6.56-6.49(\mathrm{~m}, 4 \mathrm{H}), 3.55(\mathrm{~s}, 24 \mathrm{H})$, $2.14(\mathrm{~s}, 2 \mathrm{H}) .{ }^{13} \mathrm{C}$ NMR (100 MHz, Methanol-d4): $\delta 150.9$ (4 C), 142.8, 129.8 (2 C), 128.2 (2 C), 123.9, 119.3 (4 C), 111.5 (4 C), 71.3 (12 C), 27.9.

\section{Potassium [18-Crown-6] bis(catecholato)-acetoxypropylsilicate 2b}

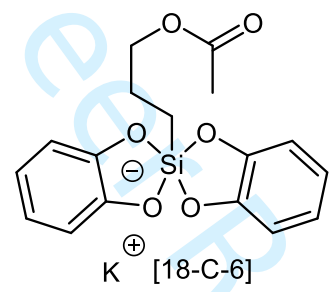

The silicate $\mathbf{2} \mathbf{b}$ was synthesized as described in General procedure 1.1. The spectroscopic data are in agreement with those reported in the literature. ${ }^{2}$

${ }^{1}$ H NMR (400 MHz, Methanol-d4): $\delta 6.68(d d, J=5.6,3.5 \mathrm{~Hz}, 4 \mathrm{H}), 6.56(\mathrm{dd}, \mathrm{J}=5.6,3.5 \mathrm{~Hz}, 4 \mathrm{H}), 3.88(\mathrm{t}, \mathrm{J}=7.0$ $\mathrm{Hz}, 2 \mathrm{H}), 1.92(\mathrm{~s}, 3 \mathrm{H}), 1.66-1.56(\mathrm{~m}, 2 \mathrm{H}), 0.70-0.65(\mathrm{~m}, 2 \mathrm{H}) .{ }^{13} \mathrm{C}$ NMR (100 MHz, Methanol-d4): $\delta$ 173.1, 150.9 (4 C), 119.3 (4 C), 111.5 (4 C), 71.2 (12 C), 68.6, 24.9, 20.8, 13.9.

Potassium [18-Crown-6] bis(catecholato)-cyclohexylsilicate 2c

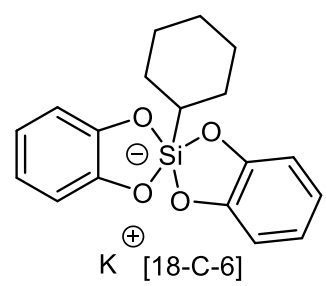

The silicate $\mathbf{2 c}$ was synthesized as described in General procedure 1.1. The spectroscopic data are in agreement with those reported in the literature and the X-ray crystal structure was previously determined.

\footnotetext{
${ }^{2}$ Lévêque, C.; Chenneberg, L.; Corcé, V.; Goddard, J.-P.; Ollivier, C.; Fensterbank, L. Org. Chem. Front. 2016, 3, 462.
} 
${ }^{1}$ H NMR (400 MHz, Methanol-d4): $\delta 6.72-6.60(\mathrm{~m}, 4 \mathrm{H}), 6.57-6.49(\mathrm{~m}, 4 \mathrm{H}), 3.53(\mathrm{~s}, 24 \mathrm{H}), 1.69-1.48(\mathrm{~m}, 5 \mathrm{H})$, $1.34-1.02(\mathrm{~m}, 5 \mathrm{H}), 0.84(\mathrm{tt}, \mathrm{J}=12.2,3.1 \mathrm{~Hz}, 1 \mathrm{H}) .{ }^{13} \mathrm{C}$ NMR (100 MHz, Methanol-d4): $\delta 151.5(4 \mathrm{C}), 119.0(4 \mathrm{C})$, 111.2 (4 C), 71.2 (12 C), 31.4, 29.6 (2 C), 29.4 (2 C), 28.3.

\section{Potassium [18-Crown-6] bis(catecholato)-anilinomethylsilicate 2d}

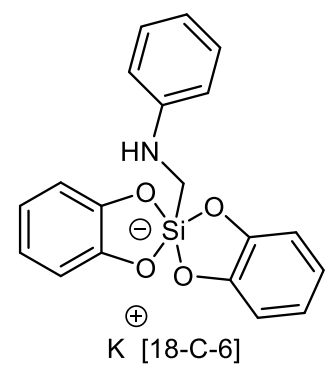

The silicate $\mathbf{2} \mathbf{d}$ was synthesized as described in General procedure 1.1. The spectroscopic data are in agreement with those reported in the literature. ${ }^{1}$

${ }^{1}$ H NMR (400 MHz, Methanol-d4): $\delta 7.27-6.90(\mathrm{~m}, 2 \mathrm{H}), 6.87-6.71(\mathrm{~m}, 4 \mathrm{H}), 6.70-6.54(\mathrm{~m}, 4 \mathrm{H}), 6.55-6.39$ (m, 3H), $3.56(\mathrm{~s}, 24 \mathrm{H}), 2.52(\mathrm{~s}, 2 \mathrm{H}), \mathrm{NH}$ is missing. ${ }^{13} \mathrm{C}$ NMR (100 MHz, Methanol-d4): $\delta 152.2,150.8(4 \mathrm{C}), 129.8$ (2 C), 119.7 (4 C), 117.0, 113.4 (2 C), 111.9 (4 C), 71.3 (12 C), 34.1.

\section{Sodium bis(catecholato)-benzylsilicate 2a-Na}

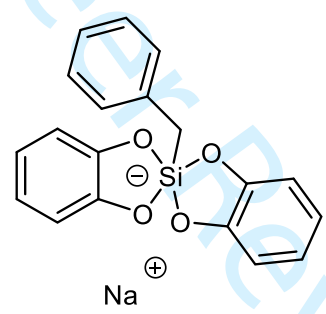

The silicate 2a-Na was synthesized as described in General procedure 1.2 with catechol (5 mmol, $0.55 \mathrm{~g})$, benzyltriethoxysilane (2.5 mmol, $0.64 \mathrm{~g}), \mathrm{MeOH}(10 \mathrm{~mL})$, NaOMe in $\mathrm{MeOH}(2.5 \mathrm{mmol}, 1.66 \mathrm{M})$. Recrystallisation was done from acetone using diethyl ether as anti-solvent affording $1.37 \mathrm{mmol}(0.49 \mathrm{~g}, 55 \%)$ of the desired silicate $2 \mathrm{a}-\mathrm{Na}$ as a white powder.

${ }^{1}$ H NMR (400 MHz, Methanol-d4): $\delta 7.00-6.93(\mathrm{~m}, 2 \mathrm{H}), 6.92-6.83(\mathrm{~m}, 3 \mathrm{H}), 6.73-6.66(\mathrm{~m}, 4 \mathrm{H}), 6.62-6.52(\mathrm{~m}$, 4H), 2.18 (s, 2H). ${ }^{13} \mathrm{C}$ NMR (100 MHz, Methanol-d4): $\delta 150.6$ (4 C), 142.7, 129.7 (2 C), 128.2 (2 C), 123.9, 119.4 (4 C), 111.6 (4 C), 27.5. ${ }^{29} \mathrm{Si}$ NMR (79 MHz, Methanol-d4): $\delta$-80.90. HRMS: calc. for $\mathrm{C}_{19} \mathrm{H}_{15} \mathrm{O}_{4} \mathrm{SiNa}_{2} 381.0530$; found 381.0529 . M.p. $>350^{\circ} \mathrm{C}$.

\section{Potassium bis(catecholato)-benzylsilicate 2a-K}

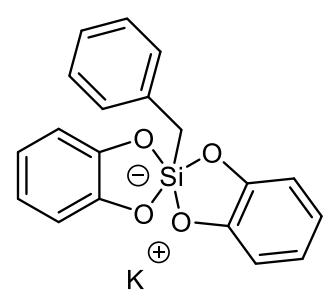

The silicate 2a-K was synthesized as described in General procedure 1.2. with catechol (5 mmol, $0.55 \mathrm{~g}$ ), benzyltriethoxysilane (2.5 mmol, $0.64 \mathrm{~g}), \mathrm{MeOH}(10 \mathrm{~mL})$, KOMe in $\mathrm{MeOH}(2.5 \mathrm{mmol}, 3.56 \mathrm{M})$. Recrystallisation 
was done from acetone using diethyl ether as anti-solvent affording $1.35 \mathrm{mmol}(0.5 \mathrm{~g}, 54 \%)$ of the desired silicate 2a-K as a grey powder. Note: Exposing the silicate to air before drying turn the powder darker.

${ }^{1}$ H NMR (400 MHz, Methanol-d4): $\delta 7.01-6.95(\mathrm{~m}, 2 \mathrm{H}), 6.91-6.84(\mathrm{~m}, 3 \mathrm{H}), 6.73-6.67(\mathrm{~m}, 4 \mathrm{H}), 6.62-6.57(\mathrm{~m}$, 4H), 2.18 (s, 2H). ${ }^{13} \mathrm{C}$ NMR (100 MHz, Methanol-d4): $\delta 150.7$ (4 C), 142.9, 129.7 (2 C), 128.2 (2 C), 123.9, 119.4 (4 C), 111.5 (4 C), 71.3 (12 C), 27.5. ${ }^{29} \mathrm{Si}$ NMR (79 MHz, Methanol-d4): $\delta$-80.90. HRMS: calc. for $\mathrm{C}_{19} \mathrm{H}_{15} \mathrm{O}_{4} \mathrm{Si}$ 335.0745; found 335.0741 . M.p. $>350^{\circ} \mathrm{C}$.

\section{Sodium [15-crown-5] bis(catecholato)-benzylsilicate 2a'}

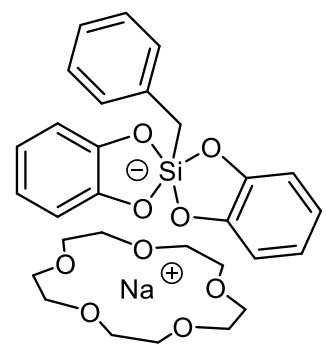

The silicate 2a' was synthesized as described in General procedure 1.2. with catechol ( $8 \mathrm{mmol}, 0.88 \mathrm{~g}$ ), benzyltriethoxysilane ( $4 \mathrm{mmol}, 1 \mathrm{~g}), \mathrm{MeOH}(16 \mathrm{~mL}), 15-\mathrm{C}-5(4 \mathrm{mmol}, 790 \mu \mathrm{L})$ that was added before $\mathrm{NaOMe}$ in $\mathrm{MeOH}(4 \mathrm{mmol}, 1.66 \mathrm{M})$. Recrystallisation was done from acetone affording $1.6 \mathrm{mmol}(0.92 \mathrm{~g}, 45 \%)$ of the desired silicate $\mathbf{2 a}$ ' as a white powder.

${ }^{1}$ H NMR (400 MHz, Methanol-d4): $\delta 6.98-6.80(\mathrm{~m}, 5 \mathrm{H}), 6.68-6.62(\mathrm{~m}, 4 \mathrm{H}), 6.59-6.53(\mathrm{~m}, 4 \mathrm{H}), 3.65(\mathrm{~s}, 20 \mathrm{H})$, 2.17 (s, 2H). ${ }^{13} \mathrm{C}$ NMR (100 MHz, Methanol-d4): $\delta 150.9$ (4 C), 142.7, 129.8 (2 C), $128.2(2 \mathrm{C}), 123.9,119.3$ (4 C), 111.5 (4 C), 69.9 (10 C), 27.8. ${ }^{29}$ Si NMR (79 MHz, Methanol-d4): $\delta$-80.80. HRMS: calc. for $\mathrm{C}_{19} \mathrm{H}_{15} \mathrm{O}_{4} \mathrm{Si} 335.0745$; found 335.0743 . M.p. $238^{\circ} \mathrm{C}$ (decomp.).

\section{Sodium bis(catecholato)-acetoxypropylsilicate $\mathbf{2 b}-\mathrm{Na}$}<smiles>CC(=O)OCCC[Si]1(Oc2ccccc2[N+](=O)[O-])Oc2ccccc2O1</smiles>

Following general procedure 1.2. with catechol (10 mmol, $1.1 \mathrm{~g})$, acetoxypropyltrimethoxysilane $(5 \mathrm{mmol}, 1.1$ $\mathrm{g}), \mathrm{MeOH}(20 \mathrm{~mL}), \mathrm{NaOMe}$ in $\mathrm{MeOH}(5 \mathrm{mmol}, 1.66 \mathrm{M})$. Recrystallisation was done from acetone using diethyl ether as anti-solvent affording $3.2 \mathrm{mmol}(1.17 \mathrm{~g}, 64 \%)$ of the desired silicate $\mathbf{2 b}$ - $\mathbf{N a}$ as a white powder.

${ }^{1}$ H NMR (400 MHz, Methanol-d4): $\delta 6.77-6.69(\mathrm{~m}, 4 \mathrm{H}), 6.63-6.57(\mathrm{~m}, 4 \mathrm{H}), 3.91(\mathrm{t}, \mathrm{J}=7.0 \mathrm{~Hz}, 2 \mathrm{H}), 1.95(\mathrm{~s}, 3 \mathrm{H})$, $1.69-1.59(\mathrm{~m}, 2 \mathrm{H}), 0.73-0.65(\mathrm{~m}, 2 \mathrm{H}) .{ }^{13} \mathrm{C}$ NMR (100 MHz, Methanol-d4): $\delta$ 173.3, $150.6(4 \mathrm{C}), 119.4(4 \mathrm{C})$, 111.6 (4 C), 68.5, 24.7, 20.8, 13.5. ${ }^{29} \mathrm{Si} \mathrm{NMR}$ (79 MHz, Methanol-d4): $\delta$-76.36. HRMS: calc. for $\left[\mathrm{C}_{17} \mathrm{H}_{17} \mathrm{O}_{6} \mathrm{SiNa}_{2}\right]$ 391.0584; found 345.0584 . M.p. $300^{\circ} \mathrm{C}$ (decomp.). 
Sodium bis(catecholato-)cyclohexylsilicate 2c-Na

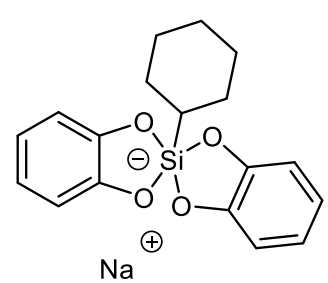

Following general procedure 1.2. with catechol (10 mmol, $1.1 \mathrm{~g})$, cyclohexyltrimethoxysilane $(5 \mathrm{mmol}, 1.02 \mathrm{~g})$, $\mathrm{MeOH}(20 \mathrm{~mL}), \mathrm{NaOMe}$ in $\mathrm{MeOH}(5 \mathrm{mmol}, 1.66 \mathrm{M})$. Recrystallisation was done from acetone affording 2.75 $\mathrm{mmol}(0.96 \mathrm{~g}, 55 \%)$ of the desired silicate $\mathbf{2 c}-\mathrm{Na}$ as a white powder.

${ }^{1}$ H NMR (300 MHz, Methanol-d4): $\delta 6.73-6.69(\mathrm{~m}, 4 \mathrm{H}), 6.60-6.55(\mathrm{~m}, 4 \mathrm{H}), 1.68-1.54(\mathrm{~m}, 5 \mathrm{H}), 1.30-1.05$ $(\mathrm{m}, 5 \mathrm{H}), 0.87(\mathrm{tt}, \mathrm{J}=12.0,3.0 \mathrm{~Hz}, 1 \mathrm{H}) .{ }^{13} \mathrm{C}$ NMR $(100 \mathrm{MHz}$, Methanol-d4): $\delta 151.3(4 \mathrm{C}), 119.1(4 \mathrm{C}), 111.2(4 \mathrm{C})$, 31.2, 29.6 (2 C), 29.3 (2 C), 28.2. ${ }^{29} \mathrm{Si}$ NMR (79 MHz, Methanol-d4): $\delta$-77.75. HRMS: calc. for $\mathrm{C}_{18} \mathrm{H}_{19} \mathrm{O}_{4} \mathrm{SiNa}_{2}$ 373.0843; found 373.0842 . M.p. $>350^{\circ} \mathrm{C}$. 


\section{Synthesis of the dihalostyryl derivatives}

\section{1-(2,2-Difluorovinyl)naphthalene (1a-F)}<smiles>FC(F)=Cc1cccc2ccccc12</smiles>

The difluoro-styryl derivative 1a-F was synthesized as described in General procedure 2.3. The spectroscopic data are in agreement with those reported in the literature. ${ }^{3}$

${ }^{1} \mathbf{H}$ NMR $\left(300 \mathrm{MHz}, \mathrm{CDCl}_{3}\right): \delta 8.01-7.76(\mathrm{~m}, 3 \mathrm{H}), 7.64-7.44(\mathrm{~m}, 4 \mathrm{H}), 5.88(\mathrm{dd}, \mathrm{J}=24.3,3.0 \mathrm{~Hz}, 1 \mathrm{H}) .{ }^{13} \mathrm{C} \mathrm{NMR}$ $\left(75 \mathrm{MHz}, \mathrm{CDCl}_{3}\right.$ ): $\delta 156.8$ (dd, J= 7.7 and $286.5 \mathrm{~Hz}$ ), 133.8, $131.6(\mathrm{~d}, \mathrm{~J}=3.4 \mathrm{~Hz}), 128.8,128.1,126.5-126.7(\mathrm{~m}$, 2C), 126.4, 125.6, 125.1, 123.9, 78.8 (dd, J=286.7 and 294.3 Hz). ${ }^{19}$ F NMR (282 MHz, $\left.\mathrm{CDCl}_{3}\right): \delta-84.9--85.1(\mathrm{~m})$, $-83.1--83.3(\mathrm{~m})$.

\section{1-(2,2-dibromovinyl)naphthalene (1a-Br)}<smiles>BrC(Br)=Cc1cccc2ccccc12</smiles>

The gem-dibromo-styryl derivative $\mathbf{1 a - B r}$ was synthesized as described in General procedure 2.2. The spectroscopic data are in agreement with those reported in the literature. ${ }^{4}$

${ }^{1} \mathbf{H}$ NMR $\left(300 \mathrm{MHz}, \mathrm{CDCl}_{3}\right): 7.99-7.84(\mathrm{~m}, 4 \mathrm{H}), 7.64(\mathrm{~d}, \mathrm{~J}=6.9 \mathrm{~Hz}, 1 \mathrm{H}), \delta 7.60-7.46(\mathrm{~m}, 3 \mathrm{H}) .{ }^{13} \mathrm{C} \mathrm{NMR}(75 \mathrm{MHz}$, $\left.\mathrm{CDCl}_{3}\right): \delta 136.0,133.6,133.3,130.8,129.0,128.7,126.9,126.7,126.3,125.4,124.3,93.0$.

\section{1-(2,2-dichlorovinyl)naphthalene (1a)}<smiles>ClC(Cl)=Cc1cccc2ccccc12</smiles>

The gem-dichloro-styryl derivative $1 \mathbf{a}$ was synthesized as described in General procedure 2.1. The spectroscopic data are in agreement with those reported in the literature. ${ }^{5}$

${ }^{1} \mathbf{H}$ NMR $\left(400 \mathrm{MHz}, \mathrm{CDCl}_{3}\right): \delta$ 7.89-7.84 (m, 2H), 7.65-7.63 (m, 1H), 7.54-7.49 (m, 3H), 7.36 (s, 1H). ${ }^{13} \mathrm{C}$ NMR $(100$ $\left.\mathrm{MHz}_{\mathrm{CDCl}}\right): \delta 133.4,131.1,130.8,128.9,128.6,127.0,126.9,126.6,126.2,125.2,124.0,123.5$.

\footnotetext{
${ }^{3}$ Zhang, B.; Zhang, X.; Hao, J.; Yang, C. Eur. J. Org. Chem. 2018, 5007.

${ }^{4}$ Ma, X.; Herzon, S. B. J. Org. Chem. 2016, 81, 8673.

${ }^{5}$ Ranu, B. C.; Samanta, S.; Das, A. Tetrahedron Lett. 2002, 43, 5993.
} 


\section{1-(2,2-dichlorovinyl)-3-methoxybenzene (1b)}<smiles>COc1cccc(C=C(Cl)Cl)c1</smiles>

The gem-dichloro-styryl derivative $\mathbf{1 b}$ was synthesized as described in General procedure 2.1. The spectroscopic data are in agreement with those reported in the literature. ${ }^{5}$

${ }^{1}$ H NMR $\left(400 \mathrm{MHz}, \mathrm{CDCl}_{3}\right): \delta$ 7.29-7.26 (m, 1H), 7.12-7.08 (m, 2H), 6.89-6.86 (m, 1H), $6.84(\mathrm{~s}, 1 \mathrm{H}), 3.82(\mathrm{~s}, 3 \mathrm{H})$.

${ }^{13} \mathrm{C}$ NMR $\left(100 \mathrm{MHz} \mathrm{CDCl}_{3}\right): \delta$ 159.5, 134.6, 129.5, 128.5, 128.5, 121.3, 114.2, 114.0, 55.3.

\section{2,2-dichlorostyrene (1c)}<smiles>ClC(Cl)=Cc1ccccc1</smiles>

The gem-dichloro-styryl derivative 1c was synthesized as described in General procedure 2.1. The spectroscopic data are in agreement with those reported in the literature. ${ }^{5}$

${ }^{1} \mathbf{H}$ NMR $\left(400 \mathrm{MHz}, \mathrm{CDCl}_{3}\right): \delta 7.61-7.51(\mathrm{~m}, 2 \mathrm{H}), 7.48-7.34(\mathrm{~m}, 4 \mathrm{H}), 6.89(\mathrm{~s}, 1 \mathrm{H}) .{ }^{13} \mathrm{C} \mathrm{NMR}\left(100 \mathrm{MHz}, \mathrm{CDCl}_{3}\right): \delta$ $133.4,128.6(2 \mathrm{C}), 128.6,128.5,128.4(2 \mathrm{C})$.

\section{1-(2,2-dichlorovinyl)-4-(trifluoromethyl)benzene (1d)}<smiles>FC(F)(F)c1ccc(C=C(Cl)Cl)cc1</smiles>

The gem-dichloro-styryl derivative $\mathbf{1 d}$ was synthesized as described in General procedure 2.1. The spectroscopic data are in agreement with those reported in the literature. ${ }^{6}$

${ }^{1} \mathbf{H}$ NMR $\left(400 \mathrm{MHz}, \mathrm{CDCl}_{3}\right): \delta 7.63(\mathrm{~m}, 4 \mathrm{H}), 6.90(\mathrm{~s}, 1 \mathrm{H}) .{ }^{13} \mathrm{C}$ NMR $\left(75 \mathrm{MHz}, \mathrm{CDCl}_{3}\right): \delta 137.0(\mathrm{q}, \mathrm{J}=1.5 \mathrm{~Hz}, 1 \mathrm{C})$, 130.4 (q, J = 32.5 Hz, 1C), $129.0(2 \mathrm{C}), 127.5(1 \mathrm{C}), 125.5$ (q, J = 3.5 Hz, 2C), $123.7(1 \mathrm{C}), 123.0$ (q, J = 270.4 Hz, 1C). ${ }^{19} \mathrm{~F}$ NMR $\left(376 \mathrm{MHz}, \mathrm{CDCl}_{3}\right): \delta-62.8$.

\section{1-(2,2-dichlorovinyl)-4-methoxybenzene (1e)}<smiles>COc1ccc(C=C(Cl)Cl)cc1</smiles>

The gem-dichloro-styryl derivative $1 \mathbf{e}$ was synthesized as described in General procedure 2.1. The spectroscopic data are in agreement with those reported in the literature. ${ }^{5}$

\footnotetext{
${ }^{6}$ Semba, K.; Kameyama, R.; Nakao, Y. Chem. Lett. 2018, 47, 213.
} 
${ }^{1} \mathbf{H}$ NMR $\left(400 \mathrm{MHz}_{\mathrm{CDCl}}\right.$ ): $87.50(\mathrm{~d}, \mathrm{~J}=8.8 \mathrm{~Hz}, 2 \mathrm{H}), 6.90(\mathrm{~d}, \mathrm{~J}=8.8 \mathrm{~Hz}, 2 \mathrm{H}), 6.79(\mathrm{~s}, 1 \mathrm{H}), 3.83(\mathrm{~s}, 3 \mathrm{H}) .{ }^{13} \mathrm{C} \mathrm{NMR}$ $\left(100 \mathrm{MHz}, \mathrm{CDCl}_{3}\right): \delta 159.7,130.2(2 \mathrm{C}), 128.2,126.1,118.9,114.0(2 \mathrm{C}), 55.4$.

\section{5-(2,2-dichlorovinyl)benzo[d][1,3]dioxole (1f)}<smiles>ClC(Cl)=Cc1ccc2c(c1)OCO2</smiles>

The gem-dichloro-styryl derivative $\mathbf{1 f}$ was synthesized as described in General procedure 2.1 The spectroscopic data are in agreement with those reported in the literature. ${ }^{7}$

\section{1-(2,2-dichlorovinyl)-4-nitrobenzene (1g)}<smiles>O=[N+]([O-])c1ccc(C=C(Cl)Cl)cc1</smiles>

The gem-dichloro-styryl derivative $1 \mathrm{~g}$ was synthesized as described in General procedure 2.1 The spectroscopic data are in agreement with those reported in the literature. ${ }^{8}$

${ }^{1} \mathrm{H}$ NMR $\left(400 \mathrm{MHz}, \mathrm{CDCl}_{3}\right): \delta 6.95(\mathrm{~s}, 1 \mathrm{H}), 7.71(\mathrm{~d}, \mathrm{~J}=8.0 \mathrm{~Hz}, 2 \mathrm{H}), 8.25(\mathrm{~d}, \mathrm{~J}=8.0 \mathrm{~Hz}, 2 \mathrm{H}) \mathrm{ppm} .{ }^{13} \mathrm{C} \mathrm{NMR}(75 \mathrm{MHz}$, $\left.\mathrm{CDCl}_{3}\right): \delta 123.9(2 \mathrm{C}), 125.4,126.9,129.5(2 \mathrm{C}), 139.7,147.3$.

\footnotetext{
${ }^{7}$ Saputra, M. A.; Ngo, L.; Kartika, R. J. Org. Chem. 2015, 80, 8815.

${ }^{8}$ Newman, S. G.; Brian, C. S.; Perez, D.; Lautens, M. Synthesis 2011, 2, 342.
} 


\section{Photoredox/nickel cross-coupling dual catalysis with the $\beta, \beta$-dichlorostyryl}

\section{(Z)-1-(2-chloro-2-benzyl)naphthalene (3aa)}<smiles>Cl/C(=C\c1cccc2ccccc12)Cc1ccccc1</smiles>

Following General procedure 3 with 1-(2,2-dichlorovinyl)naphthalene $(0.32 \mathrm{mmol}, 71 \mathrm{mg})$, potassium [18Crown-6] bis(catecholato)-benzylsilicate $(0.45 \mathrm{mmol}, 280 \mathrm{mg})$. The crude product was purified by flash column chromatography ( $\mathrm{Et}_{2} \mathrm{O}: n$-pentane From $0 / 100$ to 2/98) to afford (Z)-1-(2-chloro-2-benzyl)naphthalene (3aa) (33.5 $\mathrm{mg}, 40 \%)$ as a colorless oil.

${ }^{1} \mathbf{H}$ NMR $\left(400 \mathrm{MHz}, \mathrm{CDCl}_{3}\right): \delta 7.93-7.84(\mathrm{~m}, 2 \mathrm{H}), 7.81(\mathrm{~d}, \mathrm{~J}=8.2 \mathrm{~Hz}, 1 \mathrm{H}), 7.67(\mathrm{dt}, \mathrm{J}=7.1 \mathrm{~Hz}, 1.2 \mathrm{~Hz}, 1 \mathrm{H}), 7.53-$ $7.45(\mathrm{~m}, 3 \mathrm{H}), 7.44-7.40(\mathrm{~m}, 4 \mathrm{H}), 7.36-7.30(\mathrm{~m}, 1 \mathrm{H}), 7.00(\mathrm{~s}, 1 \mathrm{H}), 3.95(\mathrm{~s}, 2 \mathrm{H}) .{ }^{13} \mathrm{C} \mathrm{NMR}\left(\mathrm{CDCl}_{3}, 100 \mathrm{MHz}\right): \delta 137.3$, 136.3, 133.5, 132.4, 131.5, 129.2 (2C), 128.7 (2C), 128.6, 128.1, 127.2, 127.1, 126.1, 125.8, 125.2, 124.4, 124.3, 46.7. HRMS: calc. for $\mathrm{C}_{19} \mathrm{H}_{15} \mathrm{Cl} 279.0935$; found 279.0933.

\section{(Z)-4-chloro-5-(3-methoxyphenyl)benzyl (3ba)}

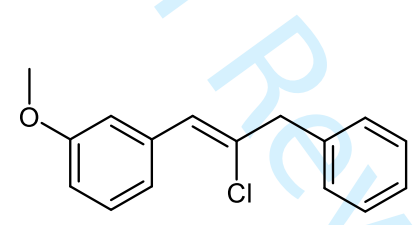

Following General procedure 3 with 1-(2,2-dichlorovinyl)-3-methoxybenzene (0.32 mmol, $64.2 \mathrm{mg}$ ) and potassium [18-Crown-6] bis(catecholato)-benzyl silicate $(0.45 \mathrm{mmol}, 280 \mathrm{mg})$. The crude product was purified by flash column chromatography ( $\mathrm{Et}_{2} \mathrm{O}: n$-pentane 2/98) to afford (Z)-4-chloro-5-(3-methoxyphenyl)benzyl (3ba) (38 $\mathrm{mg}, 48 \%$ ) as a pale brown oil.

${ }^{1} \mathbf{H}$ NMR $\left(300 \mathrm{MHz}, \mathrm{CDCl}_{3}\right): \delta 7.43-7.27(\mathrm{~m}, 6 \mathrm{H}), 7.24(\mathrm{t}, \mathrm{J}=2.1 \mathrm{~Hz}, 1 \mathrm{H}), 7.18(\mathrm{~d}, \mathrm{~J}=7.7 \mathrm{~Hz}, 1 \mathrm{H}), 6.89-6.81(\mathrm{~m}$, $1 \mathrm{H}), 6.55(\mathrm{~s}, 1 \mathrm{H}), 3.84(\mathrm{~s}, 3 \mathrm{H}), 3.82(\mathrm{~s}, 2 \mathrm{H}) .{ }^{13} \mathrm{C}$ NMR $\left(75 \mathrm{MHz} \mathrm{CDCl}_{3}\right): \delta 159.4,137.3,136.2,133.7,129.1(\mathrm{~d}, \mathrm{~J}=$ $1.9 \mathrm{~Hz}), 128.6,127.0,125.8,121.8,114.3,113.6,55.3,47.4$. HRMS: calc. for $\mathrm{C}_{16} \mathrm{H}_{15} \mathrm{ClO} 259.0884$; found 259.0883.

\section{Z-[2-chloro-1-propene-1,3-diyl]bisbenzene (3ca)}<smiles>Cl/C(=C\c1ccccc1)Cc1ccccc1</smiles>

Following General procedure 3 with (2,2-dichlorovinyl)-benzene $(0.32 \mathrm{mmol}, 55.4 \mathrm{mg}$ ) and potassium [18Crown-6] bis(catecholato)-benzyl silicate $(0.45 \mathrm{mmol}, 280 \mathrm{mg})$. The crude product was purified by flash column chromatography (Toluene) to afford the cross-coupling product Z-[2-chloro-1-propene-1,3-diyl]bisbenzene 
(3ca) (35.7 mg, $54 \%$ ). Geometry of the double bond was determined by NOESY experiment. All the spectroscopic data agree with the literature. ${ }^{7}$

${ }^{1} \mathbf{H}$ NMR $\left(400 \mathrm{MHz}, \mathrm{CDCl}_{3}\right): \delta 7.62(\mathrm{dd}, \mathrm{J}=7.5,1.7 \mathrm{~Hz}, 2 \mathrm{H}), 7.42-7.23(\mathrm{~m}, 7 \mathrm{H}), 6.56(\mathrm{~s}, 1 \mathrm{H}), 3.82(\mathrm{~s}, 2 \mathrm{H}) .{ }^{13} \mathrm{C}$ NMR (100 MHz, CDCl $)$ : $\delta 137.3,135.0,133.4,129.1$ (2C), 129.1 (2C), $128.6(2 \mathrm{C}), 128.2(2 \mathrm{C}), 127.7,127.0,125.9$, 47.3. HRMS: Calc. for $\mathrm{C}_{15} \mathrm{H}_{13} \mathrm{Cl} 228.0700$; found 228.0699 .

\section{(Z)-1-(2-chloro-3-phenylprop-1-en-1-yl)-4-(trifluoromethyl)benzene (3da)}<smiles>FC(F)(F)c1ccc(/C=C(\Cl)Cc2ccccc2)cc1</smiles>

Following General procedure 3 with 1-(2,2-dichlorovinyl)-3-(trifluoromethyl)benzene $(0.32 \mathrm{mmol}, 76 \mathrm{mg})$ and potassium [18-Crown-6] bis(catecholato)-benzylsilicate $(0.45 \mathrm{mmol}, 288 \mathrm{mg})$. The crude product was purified by flash column chromatography (Toluene:n-pentane From 0/100 to 10/90) to afford (Z)-1-(2-chloro-3phenylprop-1-en-1-yl)-4-(trifluoromethyl)benzene (3ad) $(64.3 \mathrm{mg}, 70 \%)$ as a pale oil.

${ }^{1} \mathbf{H}$ NMR $\left(\mathrm{CDCl}_{3}, 400 \mathrm{MHz}\right): \delta$ 7.70-7.66 (d, J = $\left.8 \mathrm{~Hz}, 2 \mathrm{H}\right), 7.61-7.59(\mathrm{~d}, \mathrm{~J}=8 \mathrm{~Hz}, 2 \mathrm{H}), 7.40-7.35(\mathrm{~m}, 2 \mathrm{H}), 7.32-7.27$ $(\mathrm{m}, 3 \mathrm{H}), 6.55(\mathrm{~s}, 1 \mathrm{H}), 3.83(\mathrm{~s}, 2 \mathrm{H}) .{ }^{13} \mathrm{C} \mathrm{NMR}\left(\mathrm{CDCl}_{3}, 100 \mathrm{MHz}\right): \delta 138.5,136.8,136.0,129.3(2 \mathrm{C}), 129.1(2 \mathrm{C})$, $128.7(2 \mathrm{C}), 128.3,127.2,125.1(\mathrm{q}, \mathrm{J}=3.7 \mathrm{~Hz}, 2 \mathrm{C}), 124.7,124.2(\mathrm{q}, \mathrm{J}=270.3 \mathrm{~Hz}), 47.3 \mathrm{ppm} .{ }^{19} \mathrm{~F} \mathrm{NMR}\left(\mathrm{CDCl}_{3}, 376\right.$ $\mathrm{MHz}): \delta-62.6$ ppm. HRMS: calc for $\mathrm{C}_{16} \mathrm{H}_{12} \mathrm{ClF}_{3}$ : 291.0578; found: 291.2006.

\section{(Z)-4-chloro-5-(naphthalen-1-yl)pent-4-en-1-yl acetate (3ab)}<smiles>CC(=O)OCCC/C(Cl)=C/c1cccc2ccccc12</smiles>

Following General procedure 3 with 1-(2,2-dichlorovinyl)naphthalene $(0.30 \mathrm{mmol}, 66.7 \mathrm{mg})$ and potassium [18Crown-6] bis(catecholato)- acetoxypropylsilicate $(0.45 \mathrm{mmol}, 231 \mathrm{mg})$. The crude product was purified by flash column chromatography (Et ${ }_{2} \mathrm{O}: n$-pentane From 2/98 to 10/90) to afford (Z)-4-chloro-5-(naphthalen-1-yl)pent-4en-1-yl acetate (3ab) (40 mg, 45\%) as a pale brown oil.

${ }^{1} \mathbf{H}$ NMR $\left(400 \mathrm{MHz}, \mathrm{CDCl}_{3}\right): \delta$ 7.92-7.79 (m, 3H), 7.65-7.59 (m, 1H), 7.55-7.42 (m, 3H), $6.98(\mathrm{~s}, 1 \mathrm{H}), 4.24(\mathrm{t}, \mathrm{J}=6$ $\mathrm{Hz}, 2 \mathrm{H}), 2.71(\mathrm{t}, \mathrm{J}=7.5 \mathrm{~Hz}, 2 \mathrm{H}), 2.1(\mathrm{~s}, 3 \mathrm{H}), 2.13-2.08(\mathrm{~m}, 2 \mathrm{H}) .{ }^{13} \mathrm{C}$ NMR $\left(100 \mathrm{MHz}, \mathrm{CDCl}_{3}\right): \delta 171.1,136.3,133.5$, $132.3,131.4,128.6,128.0,127.2,126.1,125.8,125.2,124.3,123.7,63.2,37.0,26.7,21.0$. HRMS: calc. for $\left[\mathrm{C}_{17} \mathrm{H}_{17} \mathrm{ClO}_{2}\right] \mathrm{Na} 311.0809$; found 311.0811 . 


\section{(Z)-4-chloro-5-(3-methoxyphenyl)pent-4-en-1-yl acetate (3bb)}<smiles>COc1cccc(/C=C(\Cl)CCCOC(C)=O)c1</smiles>

Following General procedure 3 with 1-(2,2-dichlorovinyl)-3-methoxybenzene (0.32 mmol, $64.2 \mathrm{mg}$ ) and potassium [18-Crown-6] bis(catecholato)-acetoxypropylsilicate $(0.45 \mathrm{mmol}, 293 \mathrm{mg})$. The crude product was purified by flash column chromatography (Et ${ }_{2} \mathrm{O}: n$-pentane 2/98) to afford (Z)-4-chloro-5-(3methoxyphenyl)pent-4-en-1-yl acetate (3bb) $(47.9 \mathrm{mg}, 64 \%)$ as a pale oil.

${ }^{1} \mathrm{H}$ NMR $\left(400 \mathrm{MHz}, \mathrm{CDCl}_{3}\right): \delta$ 7.24-7.28 $(\mathrm{m}, 1 \mathrm{H}), 7.02-7.19(\mathrm{~m}, 1 \mathrm{H}), 7.14-7.12(\mathrm{~m}, 1 \mathrm{H}), 6.85-6.81(\mathrm{~m}, 1 \mathrm{H}), 6.48(\mathrm{~s}$, $1 \mathrm{H}), 4.16-4.13(\mathrm{t}, \mathrm{J}=6.4 \mathrm{~Hz}, 2 \mathrm{H}), 3.82(\mathrm{~s}, 3 \mathrm{H}), 2.59-2.55(\mathrm{td}, \mathrm{J}=0.52 \mathrm{~Hz}$ and $6.7 \mathrm{~Hz}, 2 \mathrm{H}), 2.06(\mathrm{~s}, 3 \mathrm{H}), 2.05-1.94$ (m, 2H) ppm. ${ }^{13} \mathrm{C}$ NMR $\left(100 \mathrm{MHz}, \mathrm{CDCl}_{3}\right): \delta 171.1,159.4,136.2,133.7,129.1,125.1,121.7,114.3,113.4,63.2$, 55.2, 37.8, 26.7, 20.9 ppm. HRMS: calc for $\left[\mathrm{C}_{14} \mathrm{H}_{17} \mathrm{ClO}_{3}\right] \mathrm{Na:} 291.0759$; found: 291.0760 .

\section{(Z)-4-chloro-5-phenylpent-4-en-1-yl-acetate (3cb)}<smiles>CC(=O)OCCC/C(Cl)=C/c1ccccc1</smiles>

Following General procedure 3 with 1-(2,2-dichlorovinyl)-benzene $(0.32 \mathrm{mmol}, 55 \mathrm{mg})$ and sodium bis(catecholato)-acetoxypropylsilicate $(0.45 \mathrm{mmol}, 166 \mathrm{mg})$. The crude product was purified by flash column chromatography ( $\mathrm{Et}_{2} \mathrm{O}: n$-pentane 2/98) to afford (Z)-4-chloro-5-phenylpent-4-en-1-yl acetate (3cb) (25 mg, $35 \%)$ as a pale oil.

${ }^{1} \mathrm{H}$ NMR $\left(400 \mathrm{MHz}, \mathrm{CDCl}_{3}\right): \delta 7.58(\mathrm{dd}, \mathrm{J}=7.6,1.7 \mathrm{~Hz}, 2 \mathrm{H}), 7.35-7.27(\mathrm{~m}, 3 \mathrm{H}), 6.51(\mathrm{~s}, 1 \mathrm{H}), 4.15(\mathrm{t}, \mathrm{J}=6.4 \mathrm{~Hz}, 2 \mathrm{H})$, $2.58(\mathrm{t}, \mathrm{J}=7.4 \mathrm{~Hz}, 2 \mathrm{H}), 2.07(\mathrm{~s}, 3 \mathrm{H}), 2.04-1.97(\mathrm{~m}, 2 \mathrm{H}) .{ }^{13} \mathrm{C} \mathrm{NMR}\left(100 \mathrm{MHz}, \mathrm{CDCl}_{3}\right): \delta 171.0,134.9,133.4,129.0$ (2C), 128.1 (2C), 127.6, 125.2, 63.2, 37.7, 26.7, 21.0. HRMS: Calcd for $\mathrm{C}_{13} \mathrm{H}_{16} \mathrm{O}_{2} \mathrm{Cl}$ 239.0834; found 239.0833.

\section{(Z)-4-chloro-5-(4-(trifluoromethyl)phenyl)pent-4-en-1-yl acetate (3db)}<smiles>CC(=O)OCCC/C(Cl)=C/c1ccc(C(F)(F)F)cc1</smiles>

Following General procedure 3 with 1-(2,2-dichlorovinyl)-4-(trifluoromethyl)benzene (0.31 mmol, $72.3 \mathrm{mg}$ ) and potassium [18-Crown-6] bis(catecholato)-acetoxypropylsilicate $(0.45 \mathrm{mmol}, 295 \mathrm{mg})$. The crude product was 
purified by flash column chromatography (Et $2 \mathrm{O}: n$-pentane 10/90) (Z)-4-chloro-5-(4(trifluoromethyl)phenyl)pent-4-en-1-yl acetate (3db) (49 mg, 51\%) as a pale brown oil.

${ }^{1} \mathrm{H}$ NMR $\left(400 \mathrm{MHz}, \mathrm{CDCl}_{3}\right): \delta 7.69-7.66(\mathrm{~d}, \mathrm{~J}=8 \mathrm{~Hz}, 2 \mathrm{H}), 7.62-7.59(\mathrm{~d}, \mathrm{~J}=8 \mathrm{~Hz}, 2 \mathrm{H}), 6.54(\mathrm{~s}, 1 \mathrm{H}), 4.17-4.13(\mathrm{t}, \mathrm{J}=$ $6.4 \mathrm{~Hz}, 2 \mathrm{H}), 2.62-2.58(\mathrm{td}, \mathrm{J}=0.5 \mathrm{~Hz}$ and $7 \mathrm{~Hz}, 2 \mathrm{H}), 2.06(\mathrm{~s}, 3 \mathrm{H}), 2.04-1.98(\mathrm{~m}, 2 \mathrm{H}) .{ }^{13} \mathrm{C} \mathrm{NMR}\left(100 \mathrm{MHz}, \mathrm{CDCl}_{3}\right): \delta$ 171.1, 138.4, 135.9, 129.5, 129.2 (2C), 125.1(q, J=3.7Hz, 2C), 124.3 (q, J = 283.7 Hz), 124.1, 63.1, 37.7, 26.6, 20.9. ${ }^{19} \mathrm{~F}$ NMR (376 MHz, CDCl 3 ): $\delta$-62.7 ppm. HRMS: calc for $\left[\mathrm{C}_{14} \mathrm{H}_{14} \mathrm{ClF}_{3} \mathrm{O}_{2}\right] \mathrm{Na} 329.9527$; found 329.9527.

\section{(Z)-1-(2-chloro-2-cyclohexylvinyl)naphthalene (3ac)}<smiles>Cl/C(=C\c1cccc2ccccc12)C1CCCCC1</smiles>

Following General procedure 3 with 1-(2,2-dichlorovinyl)naphthalene $(0.32 \mathrm{mmol}, 71 \mathrm{mg})$ and [18-Crown-6] bis(catecholato)-cyclohexylsilicate $(0.45 \mathrm{mmol}, 290 \mathrm{mg})$. The crude product was purified by flash column chromatography ( $\mathrm{Et}_{2} \mathrm{O}: n$-pentane From $0 / 100$ to $2 / 98$ ) to afford (Z)-1-(2-chloro-2-cyclohexylvinyl)naphthalene (3ac) $(58.5 \mathrm{mg}, 70 \%)$ as a colorless oil.

${ }^{1} \mathrm{H}$ NMR $\left(400 \mathrm{MHz}, \mathrm{CDCl}_{3}\right): \delta$ 7.95-7.74 (m, 4H), 7.54-7.45 (m, 3H), 7.62-7.58 (m, 1H), $6.93(\mathrm{~s}, 1 \mathrm{H}), 2.54-.54(\mathrm{~m}$, $1 \mathrm{H}), 2.14-2.03(\mathrm{~m}, 2 \mathrm{H}), 1.94-1.85(\mathrm{~m}, 2 \mathrm{H}), 1.62-1.19(\mathrm{~m}, 5 \mathrm{H}) .{ }^{13} \mathrm{C}$ NMR $\left(100 \mathrm{MHz}, \mathrm{CDCl}_{3}\right): \delta 143.4133 .5,132.9$, $131.5,128.5,127.7,127.1,125.9,125.7,125.2,124.5,120.6,48.2,31.9$ (2C), 26.2 (2C) , 26.0. HRMS: calc for $\mathrm{C}_{18} \mathrm{H}_{19} \mathrm{Cl} 273.1174$; found 273.6994.

\section{(Z)-4-chloro-5-(3-methoxyphenyl)cyclohexane (3bc)}<smiles>COc1cccc(/C=C(\Cl)C2CCCCC2)c1</smiles>

Following general procedure 3 with 1-(2,2-dichlorovinyl)-3-methoxybenzene $(0.32 \mathrm{mmol}, 60.9 \mathrm{mg})$ and potassium [18-Crown-6] bis(catecholato)-cyclohexyl silicate $(0.45 \mathrm{mmol}, 284 \mathrm{mg})$. The crude product was purified by flash column chromatography ( $\mathrm{Et}_{2} \mathrm{O}$ :n-pentane From 0/100 to 5/95) to afford (Z)-4-chloro-5-(3methoxyphenyl)benzyl (3bc) as a yellow oil (23 $\mathrm{mg}, 30 \%)$.

${ }^{1} \mathrm{H}$ NMR $\left(400 \mathrm{MHz}, \mathrm{CDCl}_{3}\right): \delta 7.40-7.11(\mathrm{~m}, 3 \mathrm{H}), 6.81(\mathrm{dd}, \mathrm{J}=8.2,2.6 \mathrm{~Hz}, 1 \mathrm{H}), 6.45(\mathrm{~s}, 1 \mathrm{H}), 3.82(\mathrm{~s}, 3 \mathrm{H}), 2.33(\mathrm{tt}$, $\mathrm{J}=11.6,3.3 \mathrm{~Hz}, 1 \mathrm{H}), 1.94(\mathrm{~d}, \mathrm{~J}=12.5 \mathrm{~Hz}, 2 \mathrm{H}), 1.84(\mathrm{dt}, \mathrm{J}=12.8,3.1 \mathrm{~Hz}, 2 \mathrm{H}), 1.76-1.68(\mathrm{~m}, 1 \mathrm{H}), 1.57-1.12(\mathrm{~m}$, $5 \mathrm{H}) .{ }^{13} \mathrm{C}$ NMR $\left(100 \mathrm{MHz}, \mathrm{CDCl}_{3}\right): \delta 159.3,140.8,136.7,129.0,122.2,121.8,114.4,113.1,55.23,48.8,31.7(2 \mathrm{C})$, 26.2(2C), 25.9. HRMS: Calc for $\mathrm{C}_{15} \mathrm{H}_{19} \mathrm{ClO} 251.1196$; found 251.1197.

\section{(Z)-(2-chloro-2-cyclohexylvinyl)benzene (3cc)}<smiles>Cl/C(=C\c1ccccc1)C1CCCCC1</smiles> 
Following General procedure 3 with 1-(2,2-dichlorovinyl)-benzene $(0.32 \mathrm{mmol}, 55 \mathrm{mg})$ and potassium [18Crown-6] bis(catecholato)-cyclohexyl silicate $(0.45 \mathrm{mmol}, 284 \mathrm{mg})$. The crude product was purified by flash column chromatography (toluene:cyclohexane From $0 / 100$ to 5/95) to afford (Z)-(2-chloro-2cyclohexylvinyl)benzene (3cc) $(40 \mathrm{mg}, 60 \%)$ as a pale oil. All the spectroscopic data agree with the literature. ${ }^{9}$

${ }^{1} \mathrm{H}$ NMR $\left(300 \mathrm{MHz}, \mathrm{CDCl}_{3}\right): \delta 7.61(\mathrm{~d}, \mathrm{~J}=7.3 \mathrm{~Hz}, 1 \mathrm{H}), 7.40-7.32(\mathrm{~m}, 4 \mathrm{H}), 6.50(\mathrm{~s}, 1 \mathrm{H}), 2.44-2.29(\mathrm{~m}, 1 \mathrm{H}), 2.01-$ $1.69(\mathrm{~m}, 7 \mathrm{H}), 1.53-1.32(\mathrm{~m}, 3 \mathrm{H}) .{ }^{13} \mathrm{C}$ NMR $\left(75 \mathrm{MHz} \mathrm{CDCl}_{3}\right): \delta 129.2(2 \mathrm{C}), 128.1(2 \mathrm{C}), 127.3,122.3,48.8,31.7$ (2C), 29.7 (2C), 26.2, two carbons are missing.

\section{(Z)-N-(2-chloro-3-(naphthalen-1-yl)allyl)aniline (3ad)}<smiles>Cl/C(=C\c1cccc2ccccc12)CNc1ccccc1</smiles>

Following General procedure 3 with 1-(2,2-dichlorovinyl)naphthalene $(0.32 \mathrm{mmol}, 71 \mathrm{mg}$ ) and potassium [18Crown-6] bis(catecholato)-anilinomethylsilicate $(0.45 \mathrm{mmol}, 294 \mathrm{mg})$. The crude product was purified by flash column chromatography ( $\mathrm{Et}_{2} \mathrm{O}: n$-pentane From 2/98 to 10/90) to afford (Z)-N-(2-chloro-3-(naphthalen-1yl)allyl)aniline (3ad) (39 mg, $43 \%$ ) as a pale brown oil.

${ }^{1} \mathbf{H}$ NMR $\left(400 \mathrm{MHz}, \mathrm{CDCl}_{3}\right): \delta$ 7.82-7.78 $(\mathrm{m}, 2 \mathrm{H}), 7.65-7.59(\mathrm{~m}, 2 \mathrm{H}), 7.49-7.37(\mathrm{~m}, 3 \mathrm{H}), 7.29-7.24(\mathrm{~m}, 3 \mathrm{H}), 6.84-$ $6.75(\mathrm{~m}, 3 \mathrm{H}), 4.23(\mathrm{~s}, 2 \mathrm{H}), \mathrm{NH}$ is missing. ${ }^{13} \mathrm{C}$ NMR $\left(100 \mathrm{MHz}, \mathrm{CDCl}_{3}\right): \delta 133.7,133.4,131.8,131.5,129.4(2 \mathrm{C})$, $128.4,128.1,126.9,126.1,125.8,125.2,124.4,123.3,113.4$ (2C), 118.5, 113.5, 51.5. HRMS: calc. for $\left[\mathrm{C}_{19} \mathrm{H}_{17} \mathrm{ClN}\right]^{+}$294.1044, found: 294.1055.

\section{(Z)-N-(2-chloro-3-(3-methoxyphenyl)allyl)aniline (3bd)}<smiles>COc1cccc(/C=C(\Cl)CNc2ccccc2)c1</smiles>

Following General procedure 3 with 1-(2,2-dichlorovinyl)-3-methoxybenzene $(0.73 \mathrm{mmol}, 149 \mathrm{mg})$ and potassium [18-Crown-6] bis(catecholato)-anilinomethylsilicate $(1.09 \mathrm{mmol}, 713 \mathrm{mg})$. The crude product was purified by flash column chromatography (Et ${ }_{2} \mathrm{O}: n$-pentane From 2/98 to 10/90) to afford (Z)-N-(2-chloro-3-(3methoxyphenyl)allyl)aniline (3bd) (110 mg, $57 \%$ ) as a pale brown oil.

${ }^{1} \mathrm{H}$ NMR $\left(400 \mathrm{MHz}, \mathrm{CDCl}_{3}\right): \delta 7.19-7.05(\mathrm{~m}, 5 \mathrm{H}), 6.77-6.58(\mathrm{~m}, 5 \mathrm{H}), 4.15(\mathrm{~m}, 1 \mathrm{H}), 4,01(\mathrm{~d}, \mathrm{~J}=2.6 \mathrm{~Hz}, 2 \mathrm{H}), 3.72$ $(\mathrm{s}, 3 \mathrm{H}), \mathrm{NH}$ is missing. ${ }^{13} \mathrm{C}$ NMR $\left(100 \mathrm{MHz}, \mathrm{CDCl}_{3}\right): \delta 159.4,147.0,135.7,131.5,129.3(2 \mathrm{C}), 129.2,124.4,121.8$, 118.3, 114.4, 113.9, $113.1(2 \mathrm{C}), 55.3,52.1$. HRMS: calc. for $\left[\mathrm{C}_{16} \mathrm{H}_{17} \mathrm{CINO}\right]^{+}: 274.0993$, found: 274.099 .

\footnotetext{
9 Adak, T.; Hoffmann, M.; Witzel, S.; Rudolph, M.; Dreuw, A.; Hashmi, S. K. Chem. Eur. J. 2020, 26, 15573.
} 
<smiles>FC(F)(F)c1ccc(/C=C(\Cl)CNc2ccccc2)cc1</smiles>

Following General procedure 3 with 1-(2,2-dichlorovinyl)-4-(trifluoromethyl)benzene $(0.30 \mathrm{mmol}, 72.3 \mathrm{mg})$ and potassium [18-Crown-6] bis(catecholato)-anilinomethylsilicate $(0.45 \mathrm{mmol}, 294 \mathrm{mg})$. The crude product was purified by flash column chromatography (Et ${ }_{2} \mathrm{O}: n$-pentane $\left.10 / 90\right)$ to afford (Z)-N-(2-chloro-3-(4(trifluoromethyl)phenyl)allyl)aniline (3dd) (28 mg, 30\%) as a pale brown oil.

${ }^{1} \mathrm{H}$ NMR $\left(300 \mathrm{MHz}, \mathrm{CDCl}_{3}\right): \delta 7.67(\mathrm{~d}, \mathrm{~J}=8.4 \mathrm{~Hz}, 2 \mathrm{H}), 7.58(\mathrm{~d}, \mathrm{~J}=8.4 \mathrm{~Hz}, 2 \mathrm{H}), 7.25-7.17(\mathrm{~m}, 2 \mathrm{H}), 6.84-6.62$ $(\mathrm{m}, 4 \mathrm{H}), 4.25(\mathrm{~s}, 1 \mathrm{H}), 4.11(\mathrm{~s}, 2 \mathrm{H}) .{ }^{13} \mathrm{C}$ NMR $\left(75 \mathrm{MHz} \mathrm{CDCl}_{3}\right): \delta 146.9,138.1(\mathrm{~d}, \mathrm{~J}=1.3 \mathrm{~Hz}, 1 \mathrm{C}), 133.9,129.6(\mathrm{~d}, \mathrm{~J}=$ $58.0 \mathrm{~Hz}, 1 \mathrm{C}$ ), $129.5(2 \mathrm{C}), 129.4(2 \mathrm{C}), 125.2$ (q, J = 3.75 Hz, 2C), 124.2 (q, J = 270.3 Hz, 1C), 123.2, 118.6, 113.2 (2C), 52.1. ${ }^{19} \mathrm{~F} \mathrm{NMR}\left(376 \mathrm{MHz}, \mathrm{CDCl}_{3}\right.$ ): $\delta$-62.7. HRMS: Calc. for $\left[\mathrm{C}_{16} \mathrm{H}_{13} \mathrm{ClF}_{3} \mathrm{~N}\right]$ 312.0761; found 312.0761. 


\section{IV. ${ }^{1} \mathrm{H},{ }^{13} \mathrm{C},{ }^{19} \mathrm{~F}$ and ${ }^{29} \mathrm{Si}$ spectra}

\section{Bis-catecholato silicates}

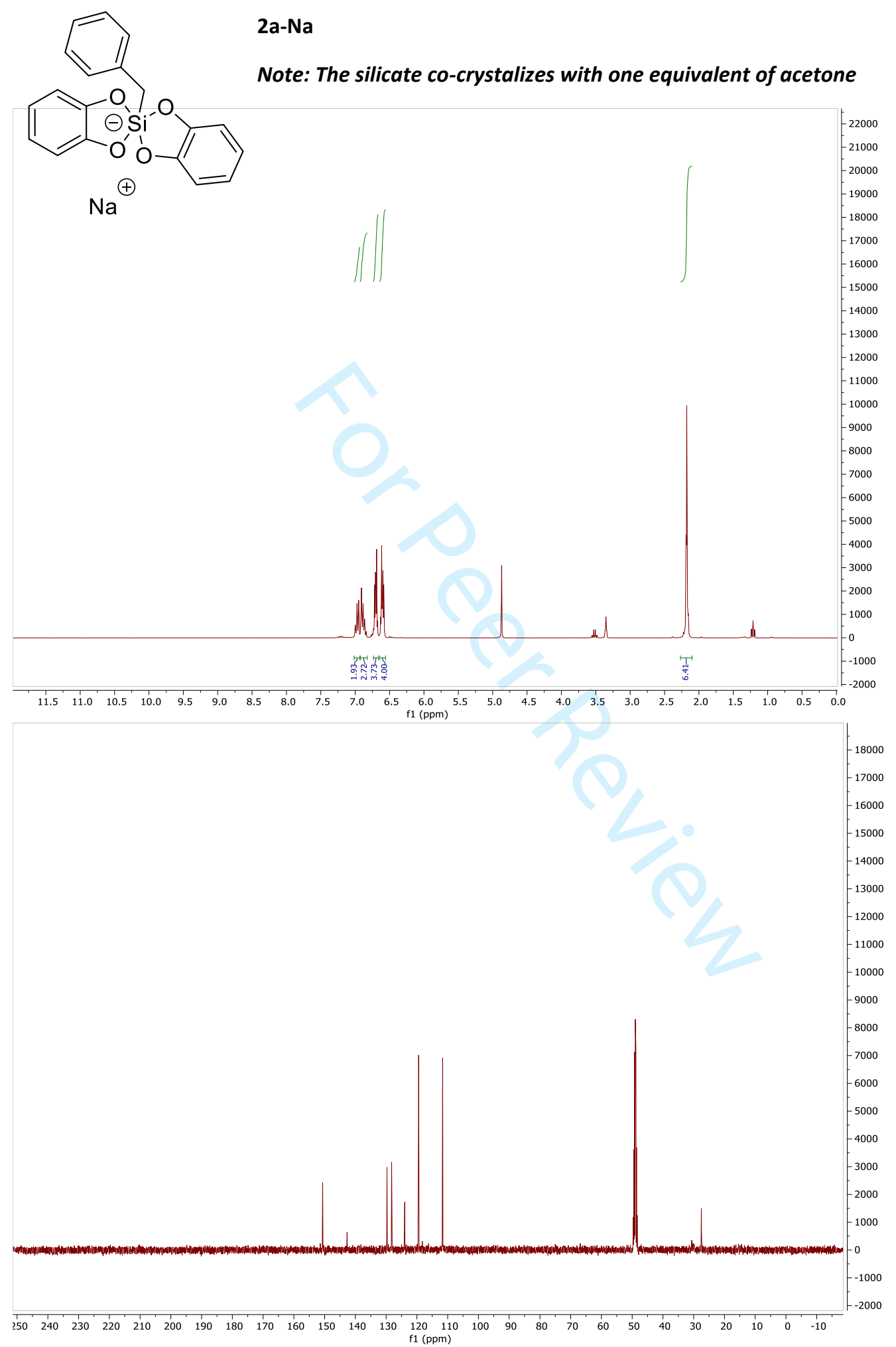




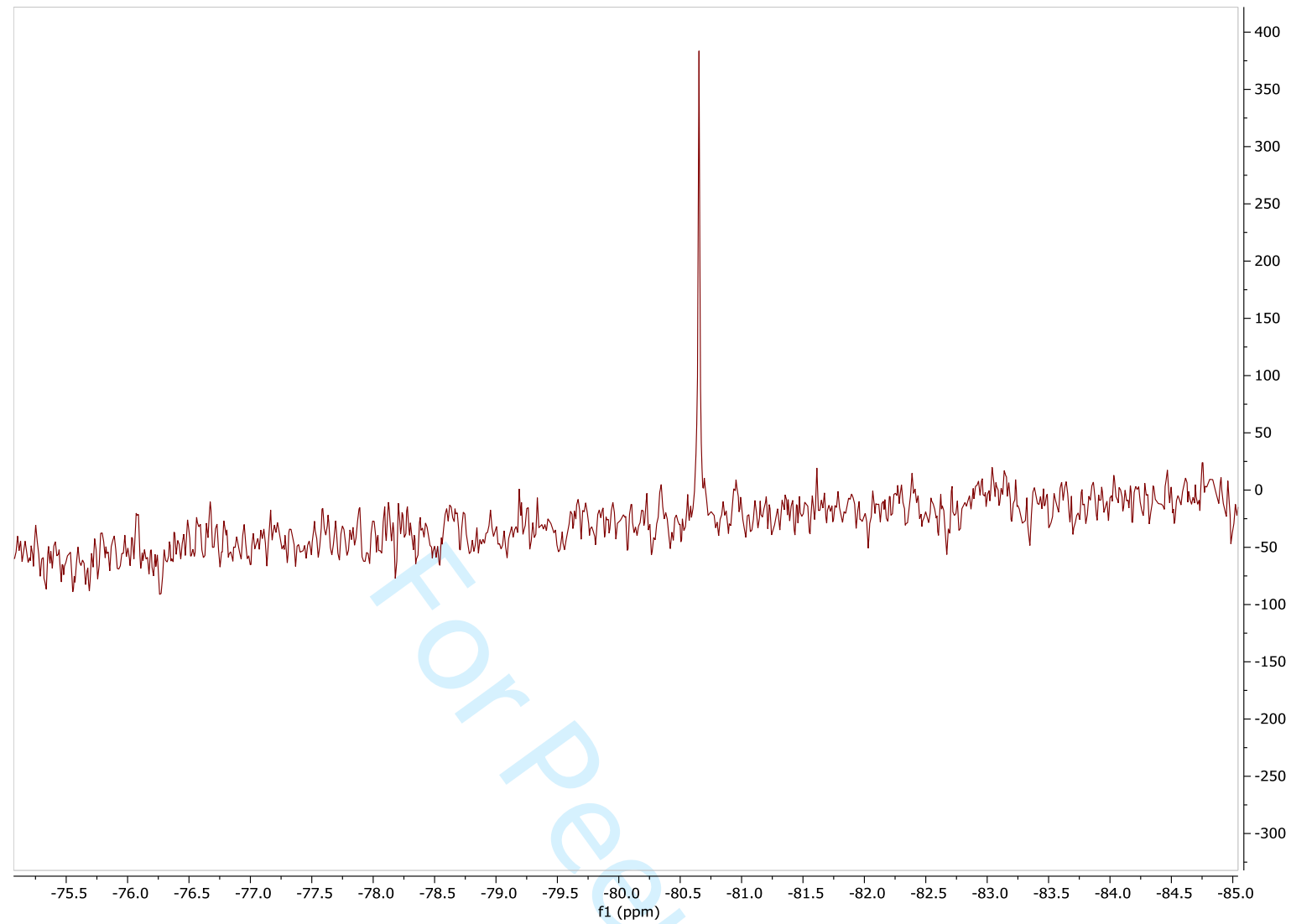


<smiles>[R20][Si]1(Cc2ccccc2)Oc2ccccc2O1</smiles>

Note: The silicate co-crystalizes with one equivalent of acetone

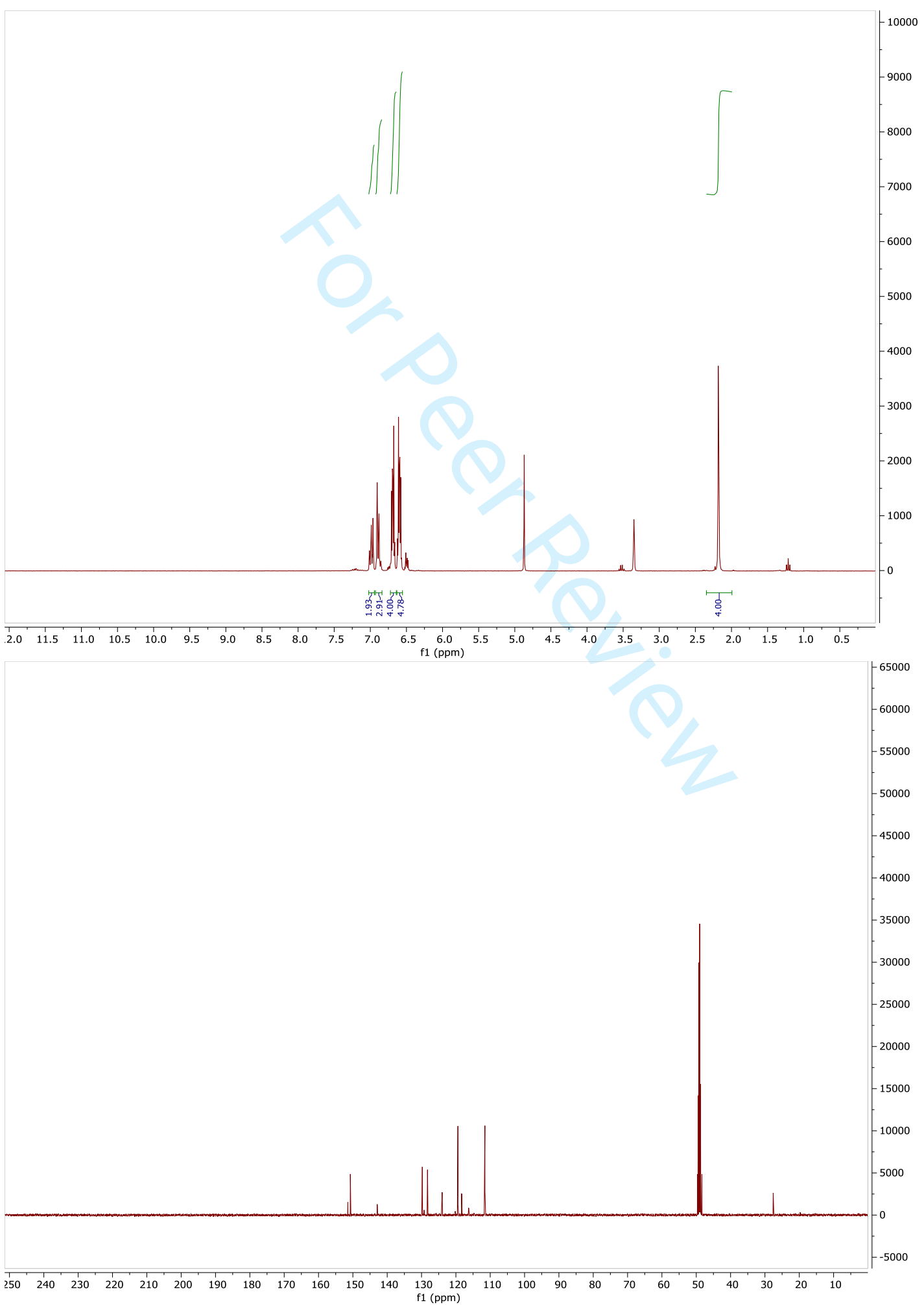




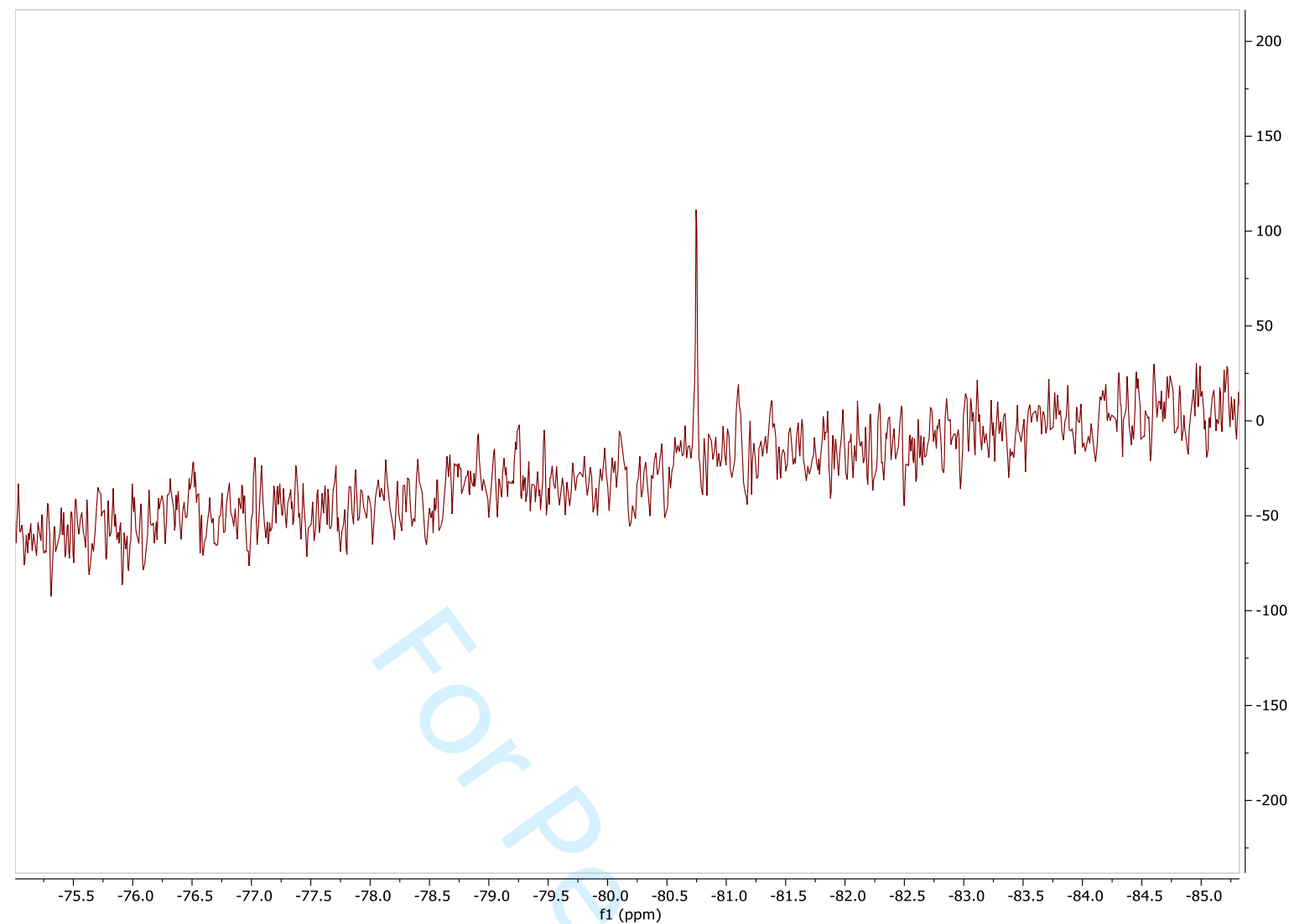



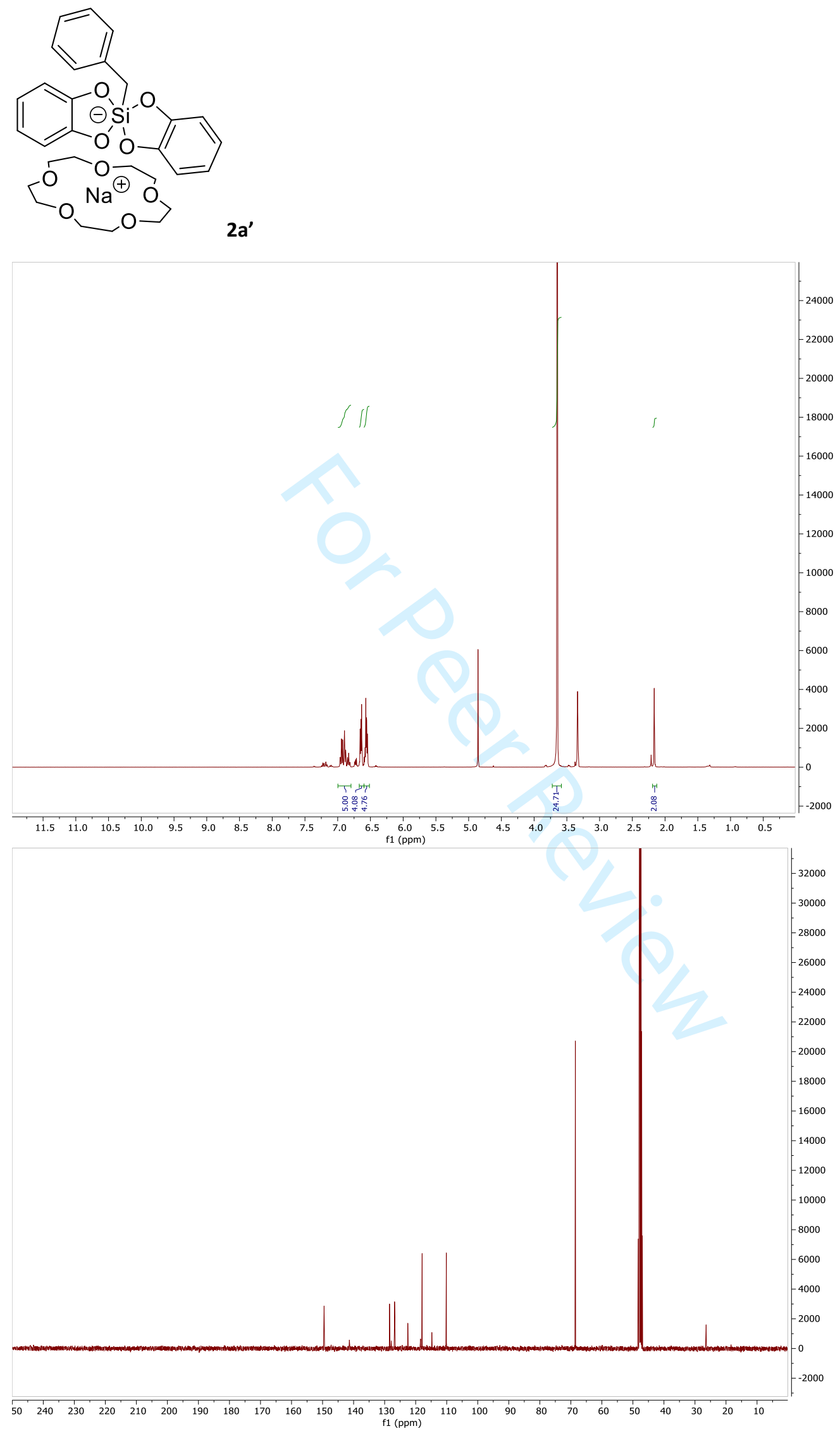


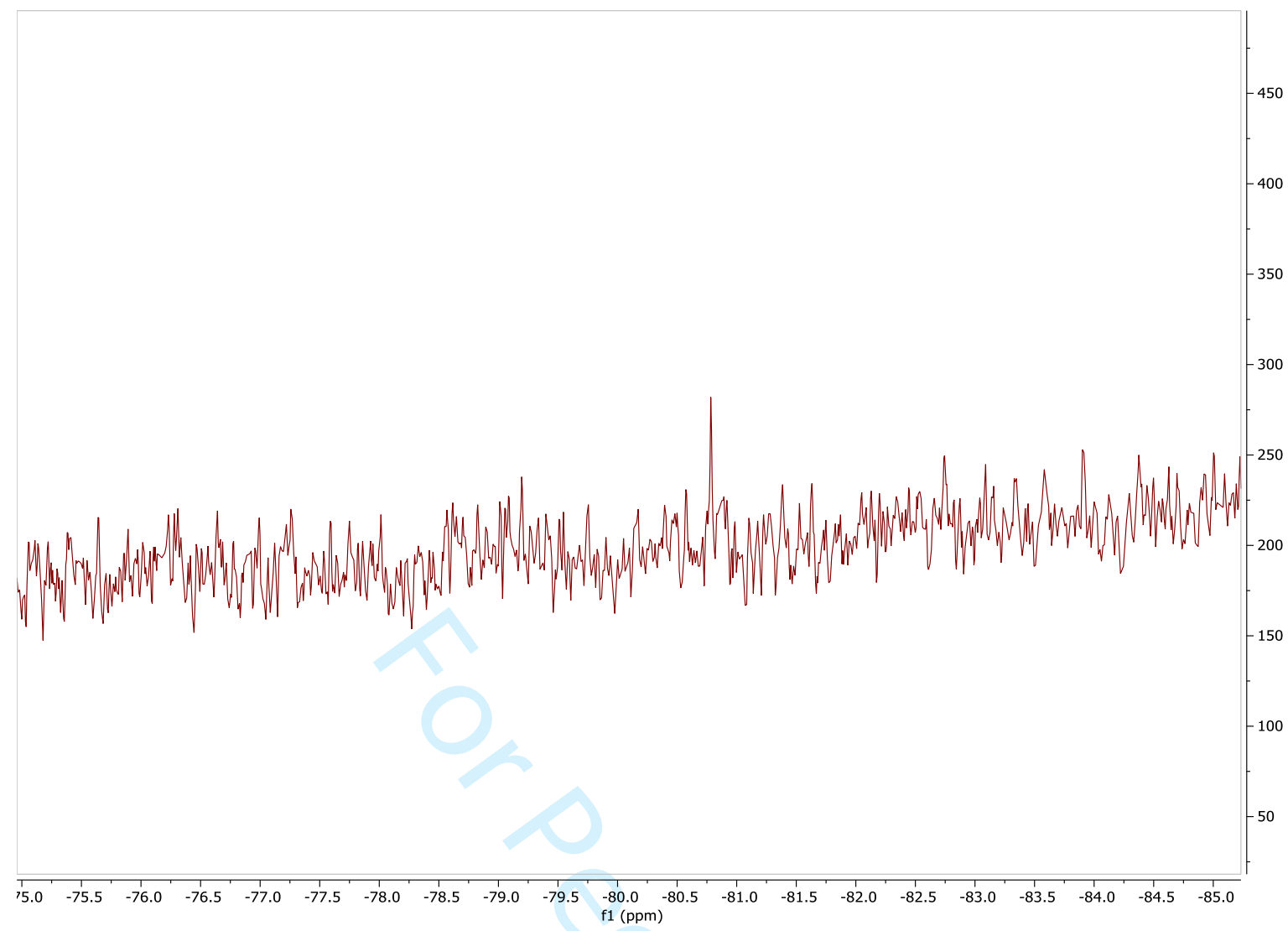


<smiles>CC(=O)OCCC[Si]1(C)Oc2ccccc2O1</smiles>

Note: The silicate co-crystalizes with one equivalent of acetone

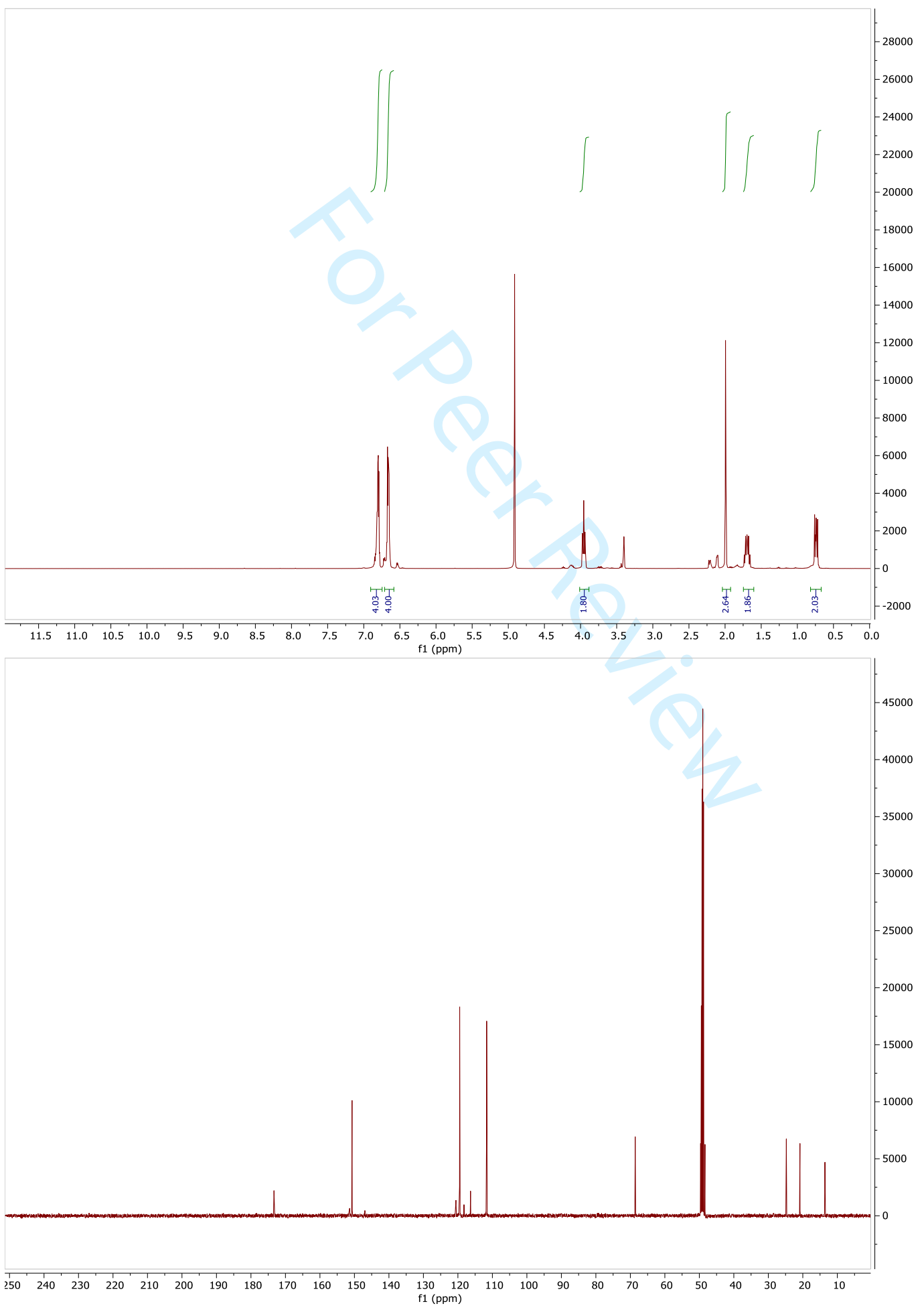




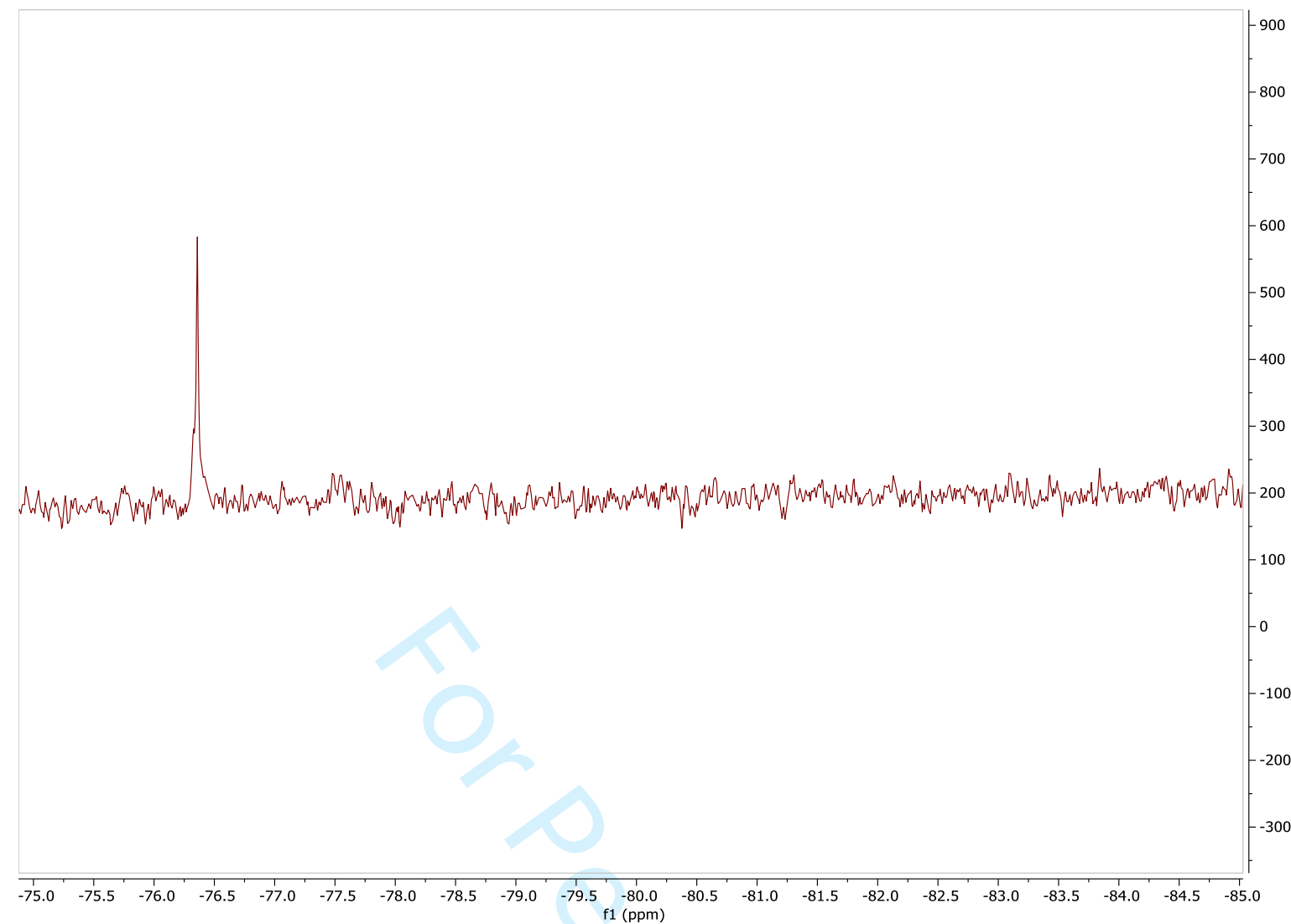




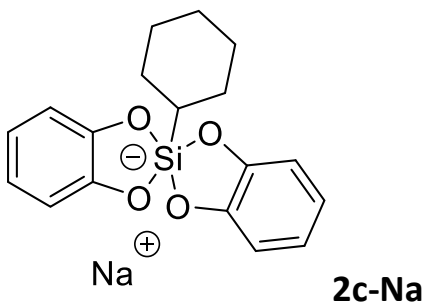

Note: The silicate co-crystalizes with one equivalent of acetone

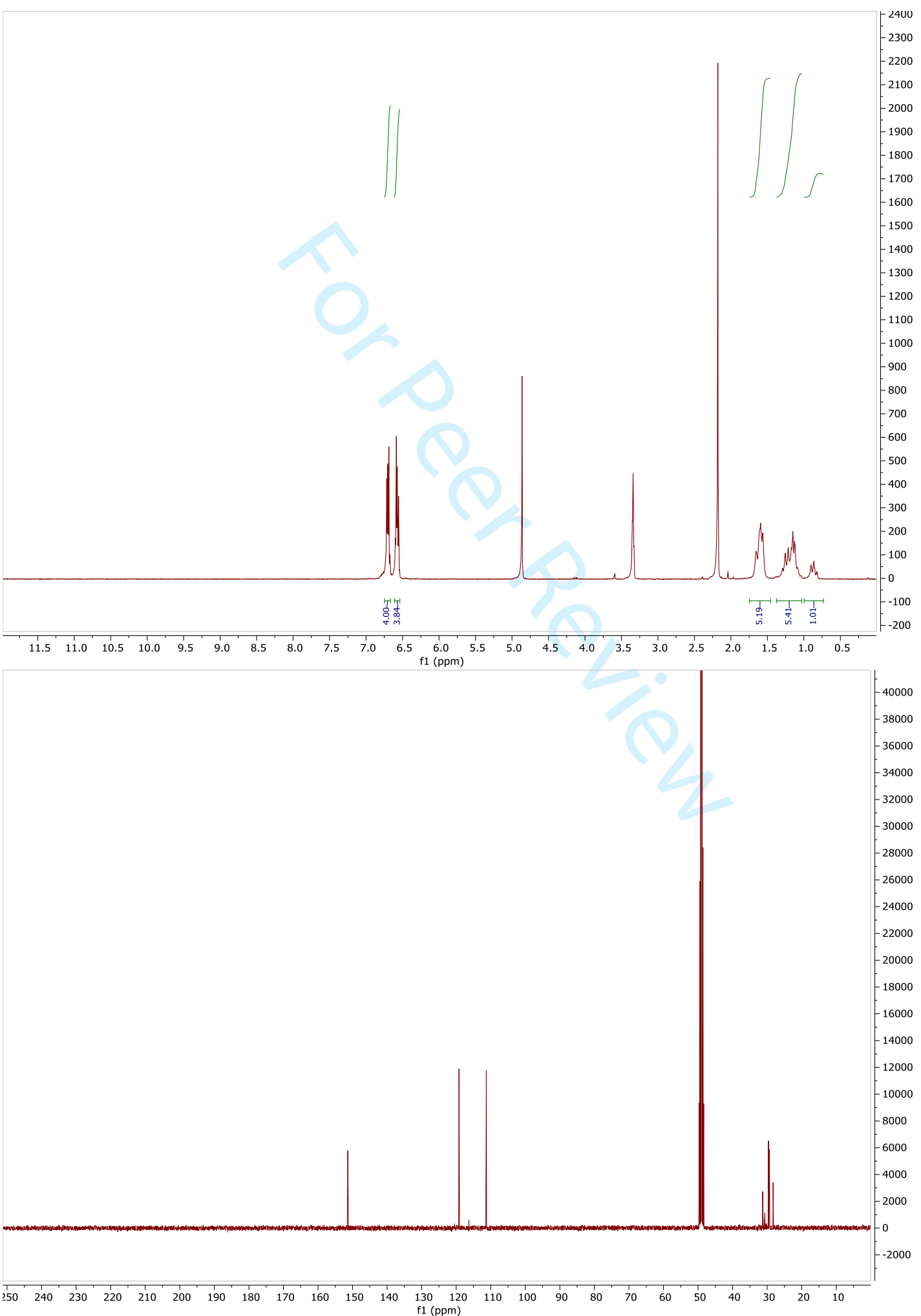




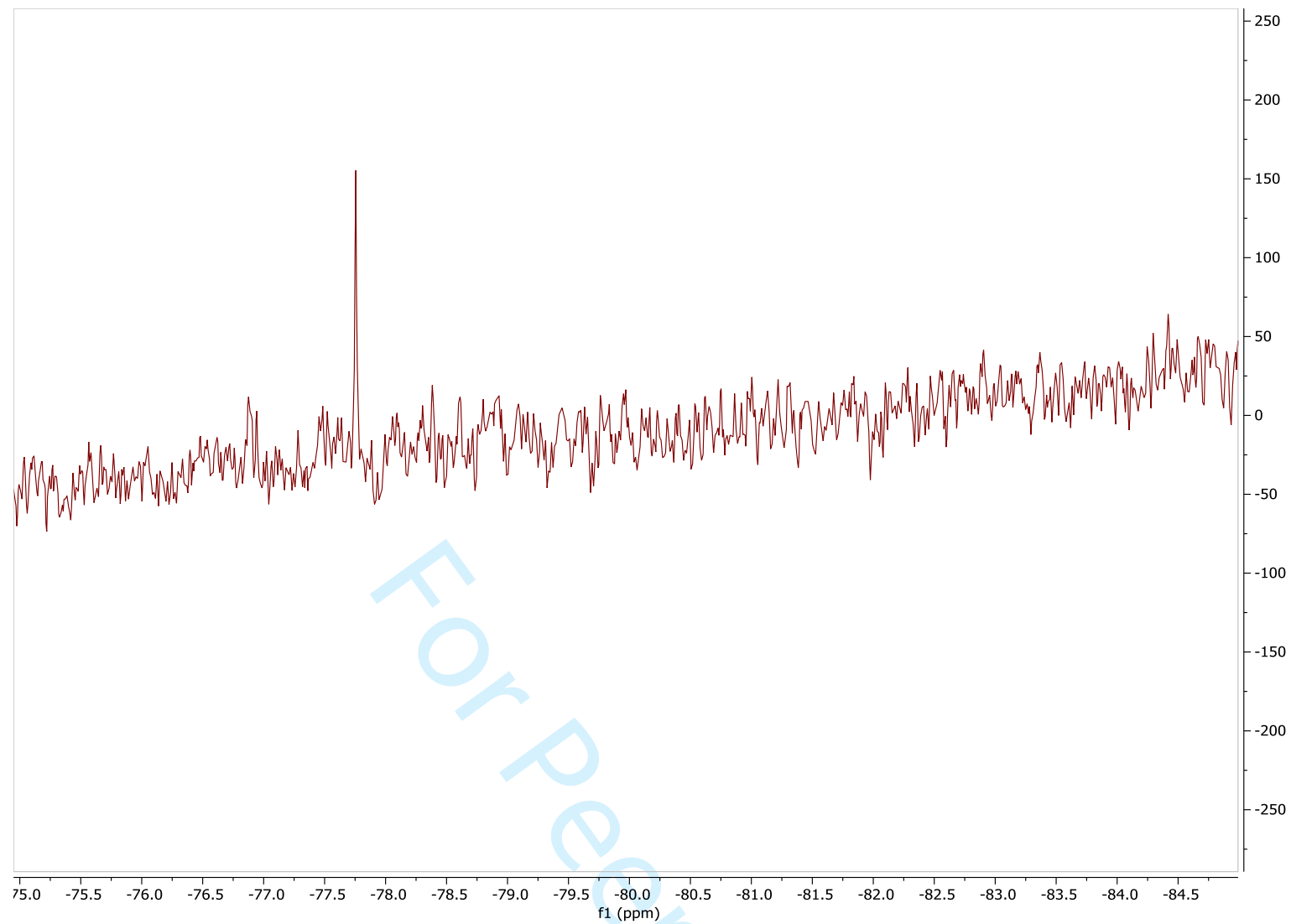




\section{Cross-coupling products}

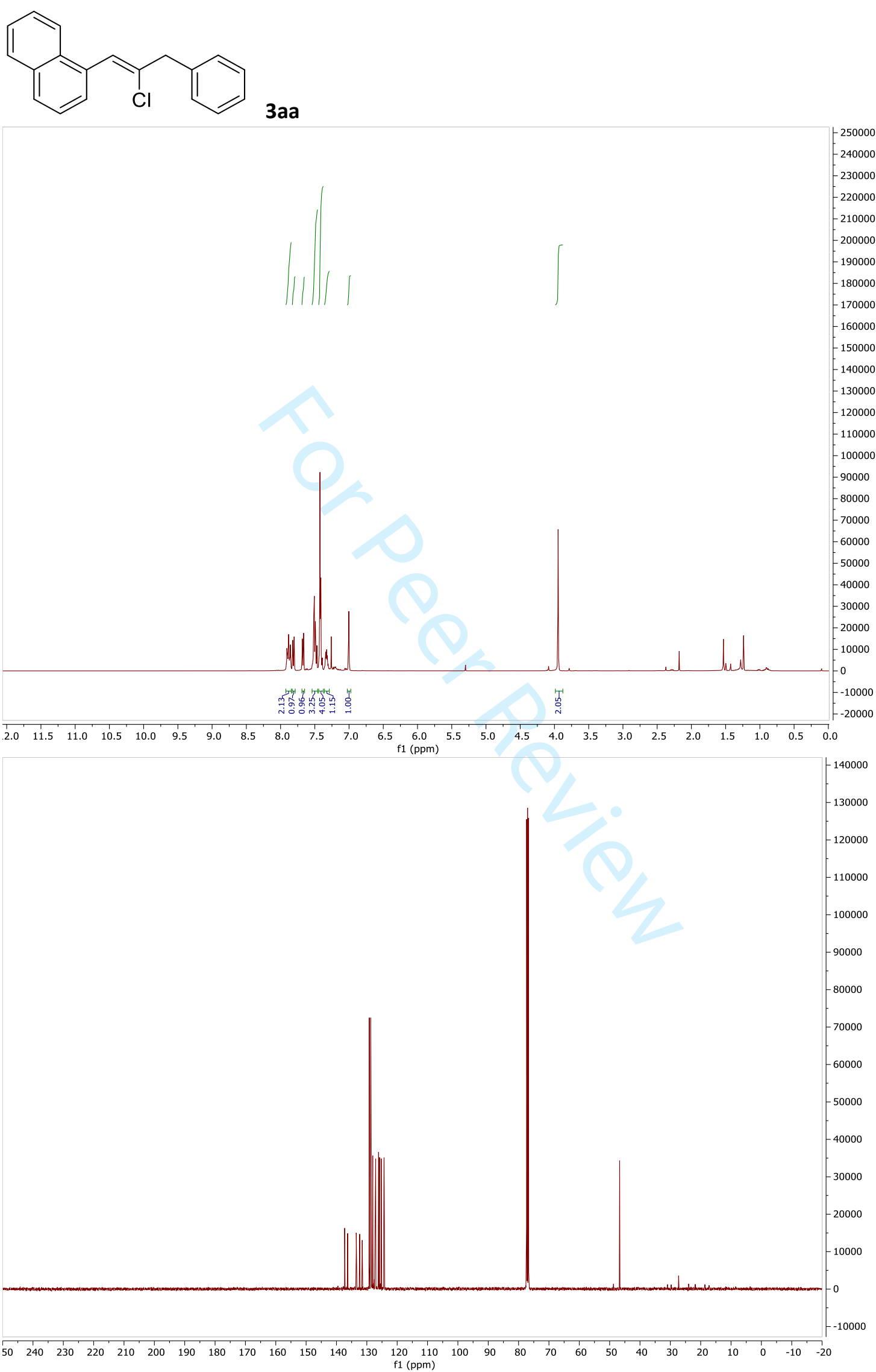


Page 35 of 56

Manuscript Submitted to Synlett
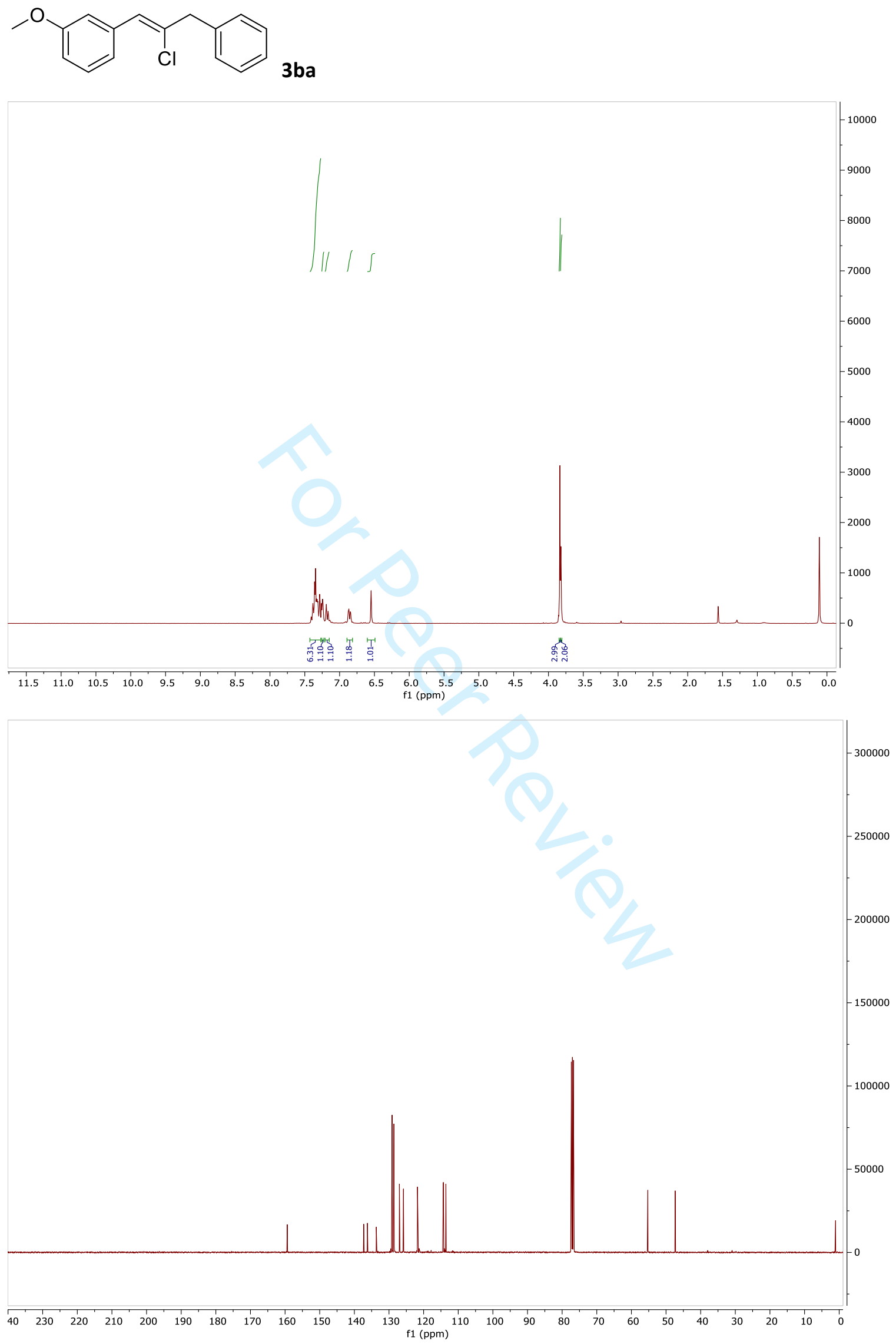

S30

Georg Thieme Publishers KG, Rüdigerstraße 14, 70469 Stuttgart, Germany 


\section{$3 c a$}
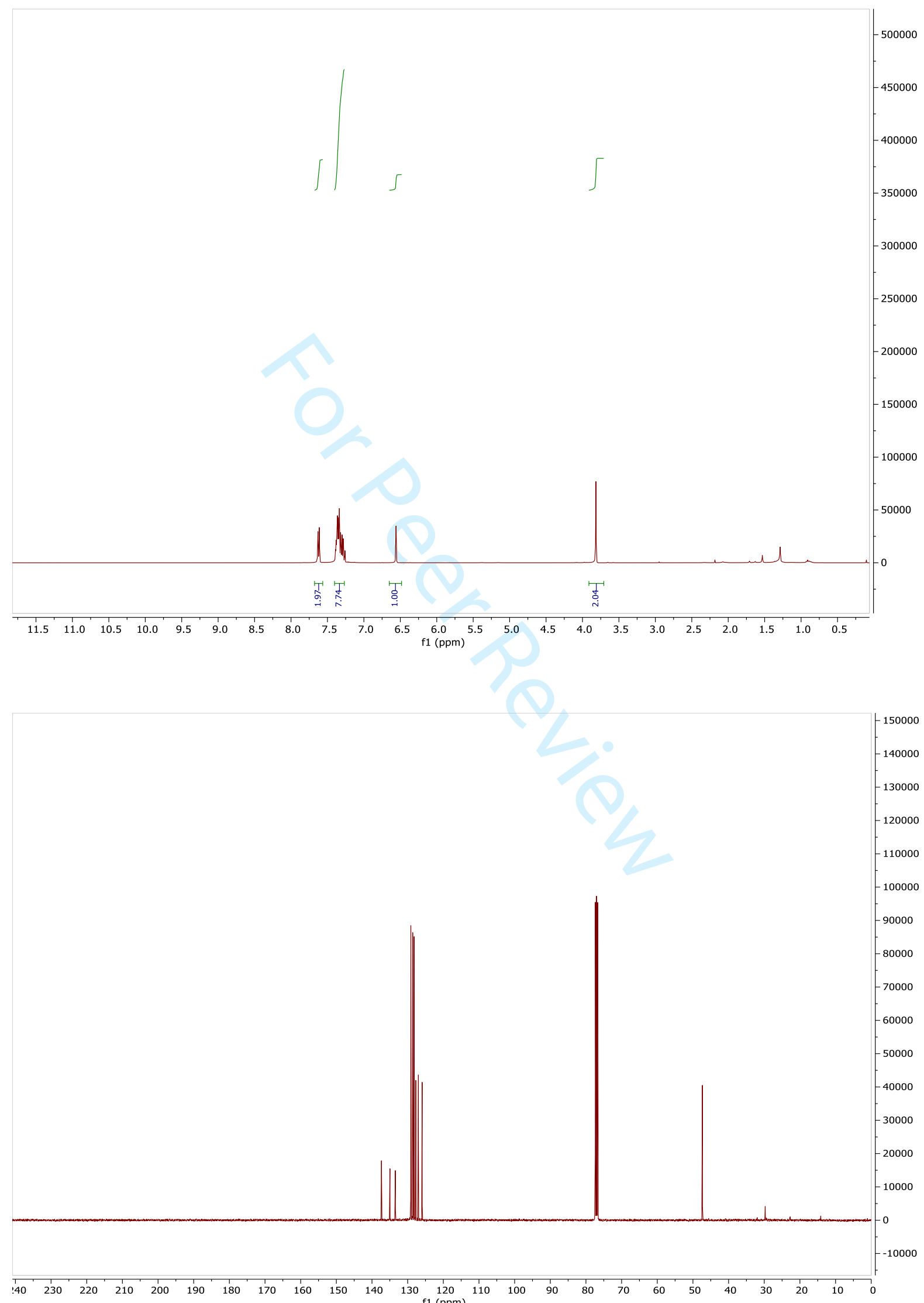
<smiles>FC(F)(F)c1ccc(/C=C(\Cl)Cc2ccccc2)cc1</smiles>
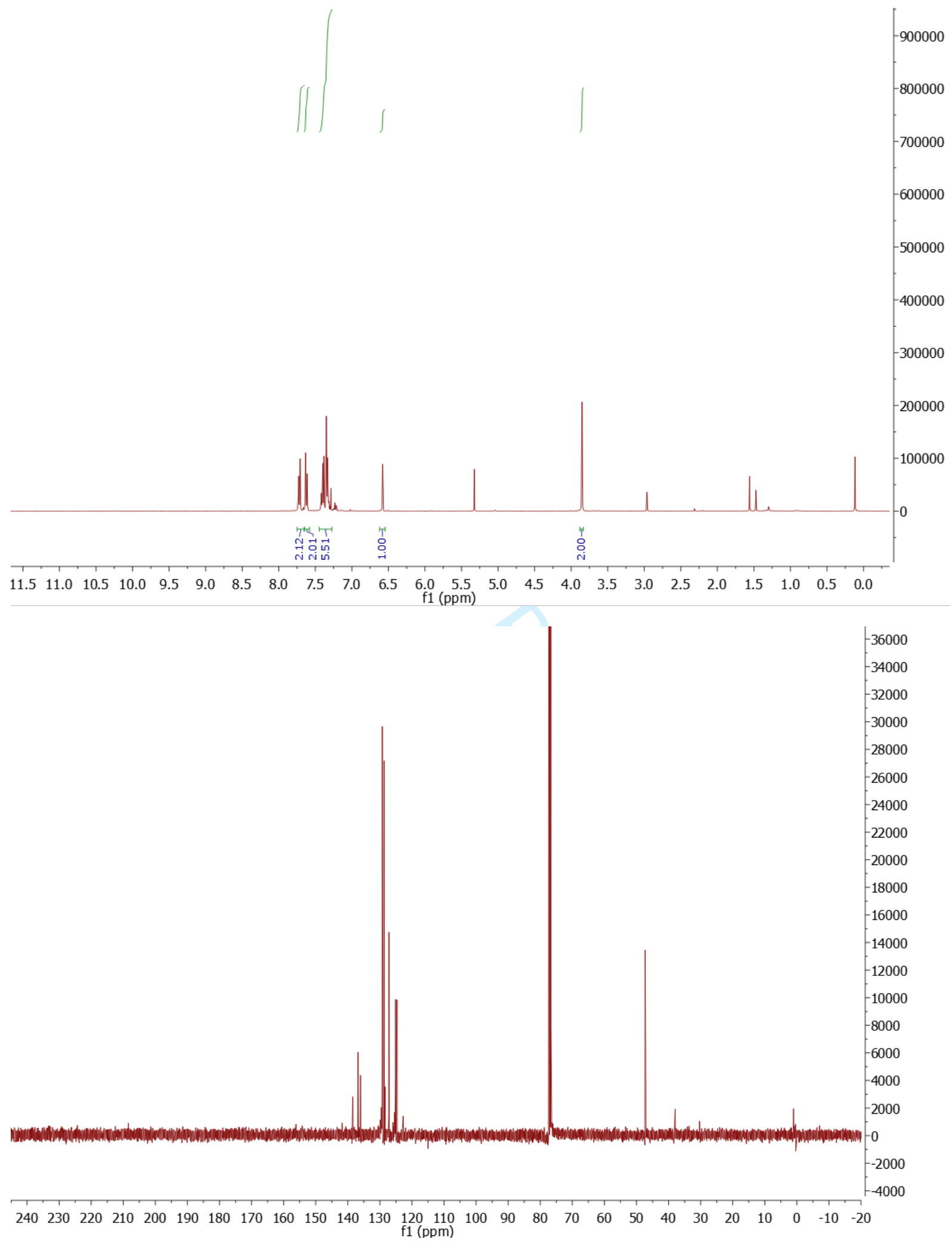


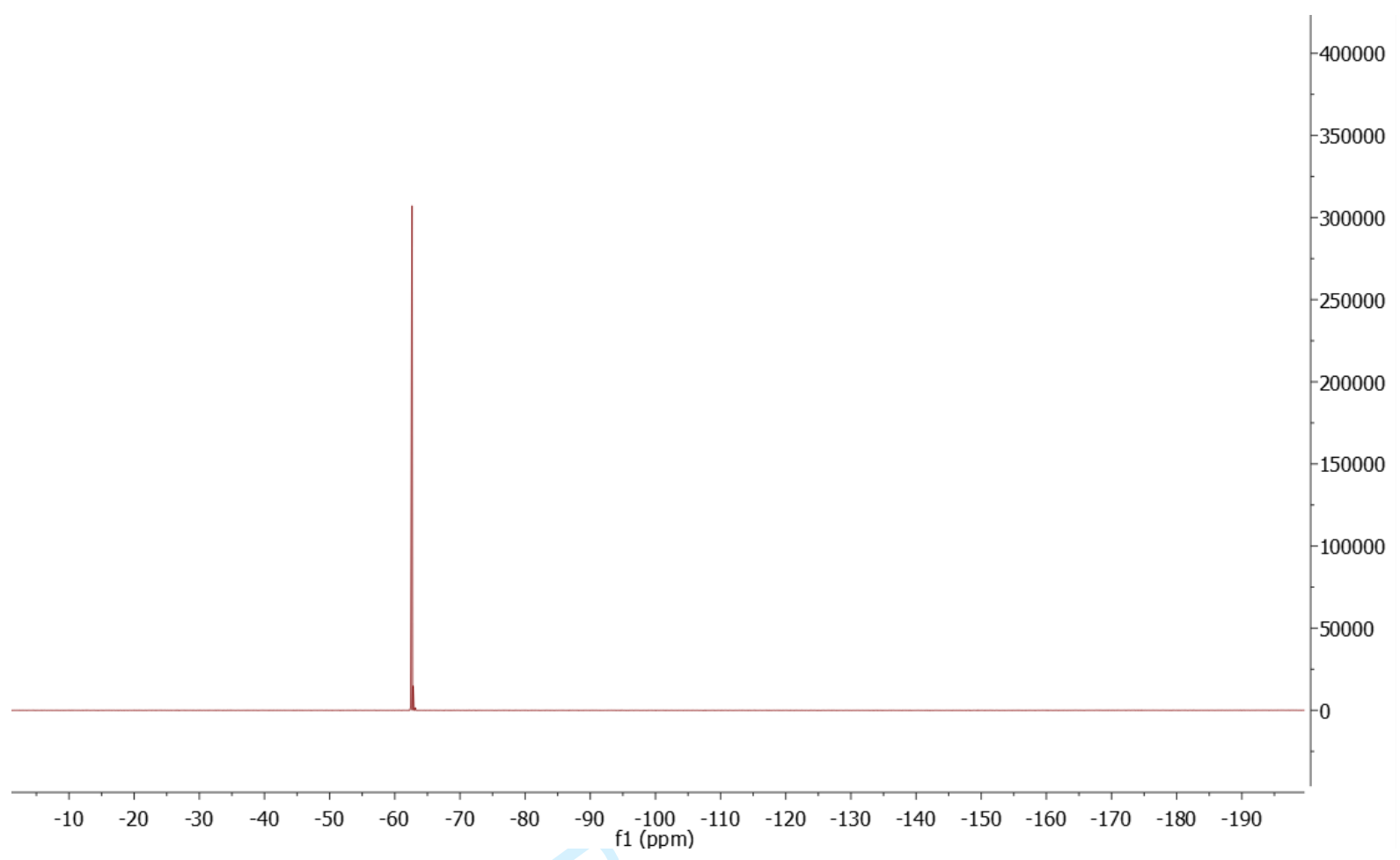



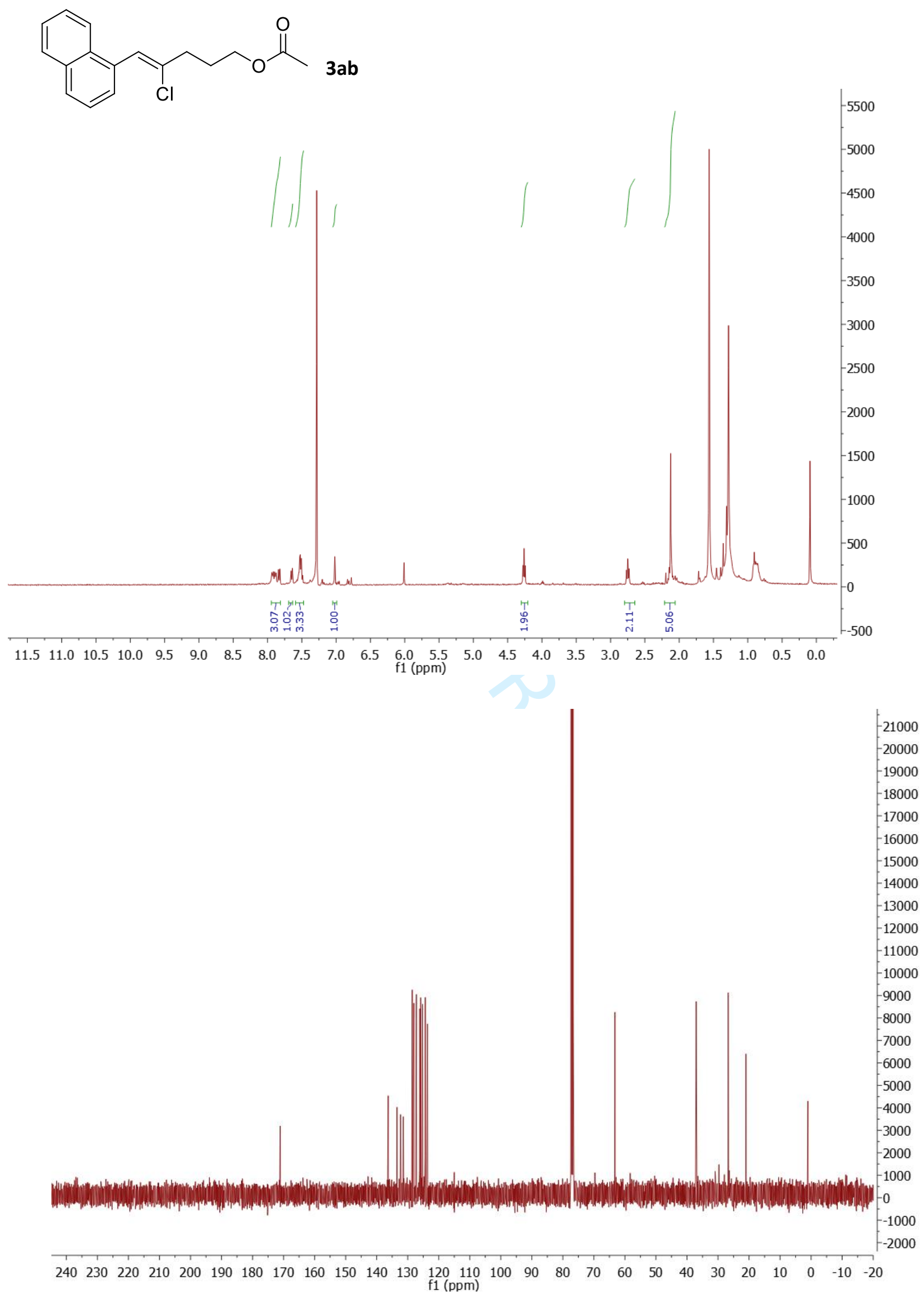
<smiles>COc1cccc(/C=C(\Cl)CCCOC(C)=O)c1</smiles>

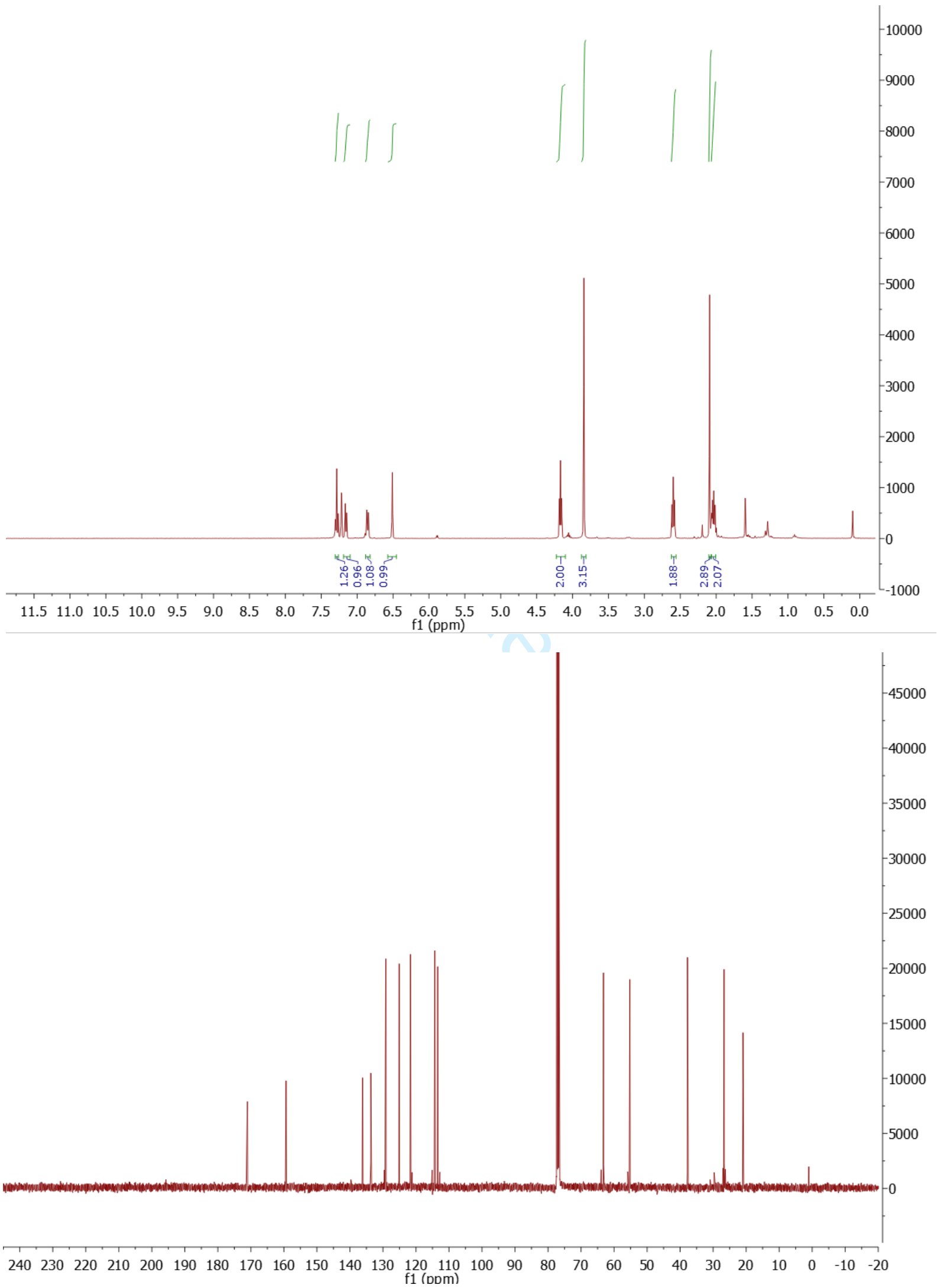


$\overbrace{\mathrm{Cl}}^{\mathrm{O}}$

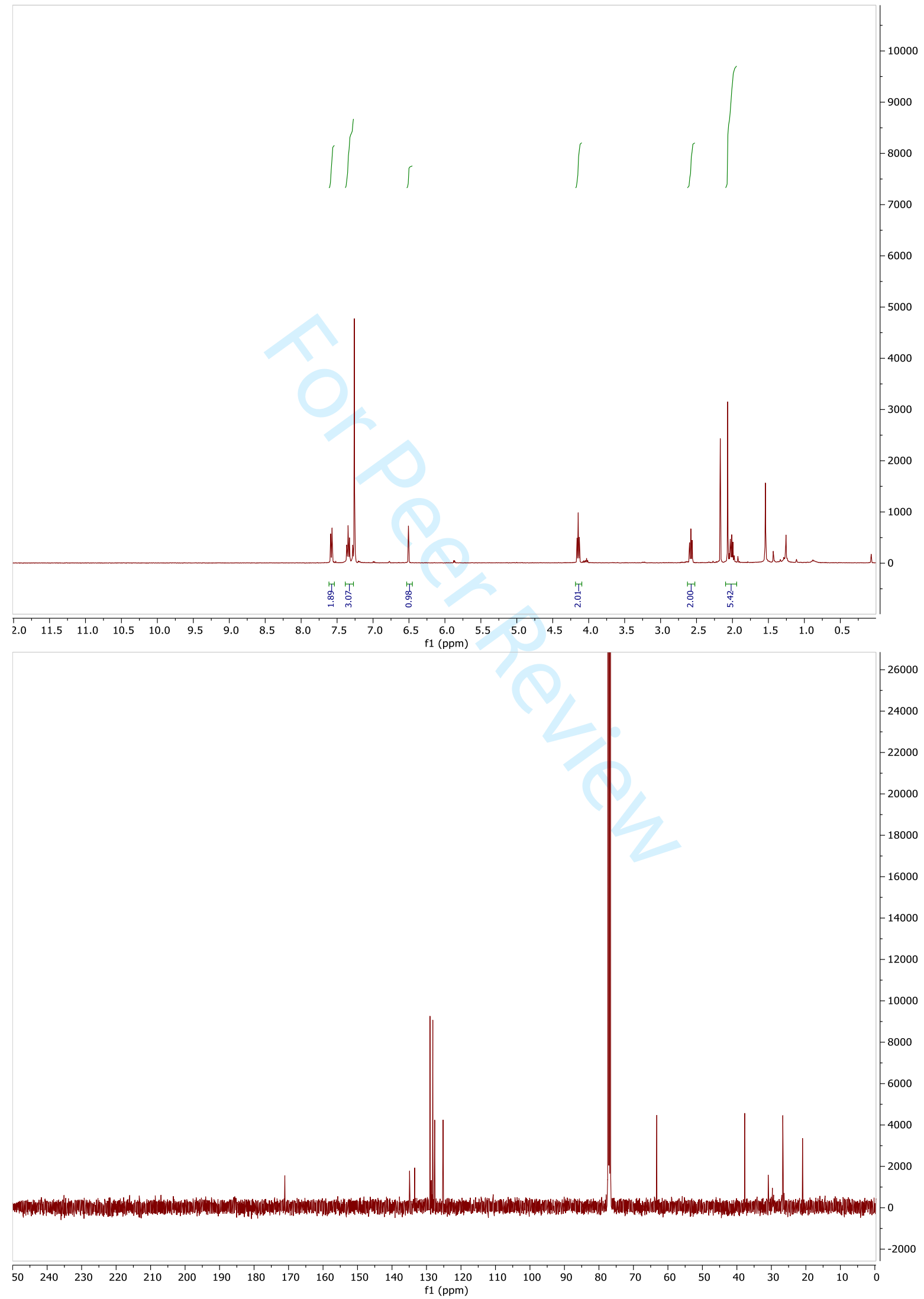



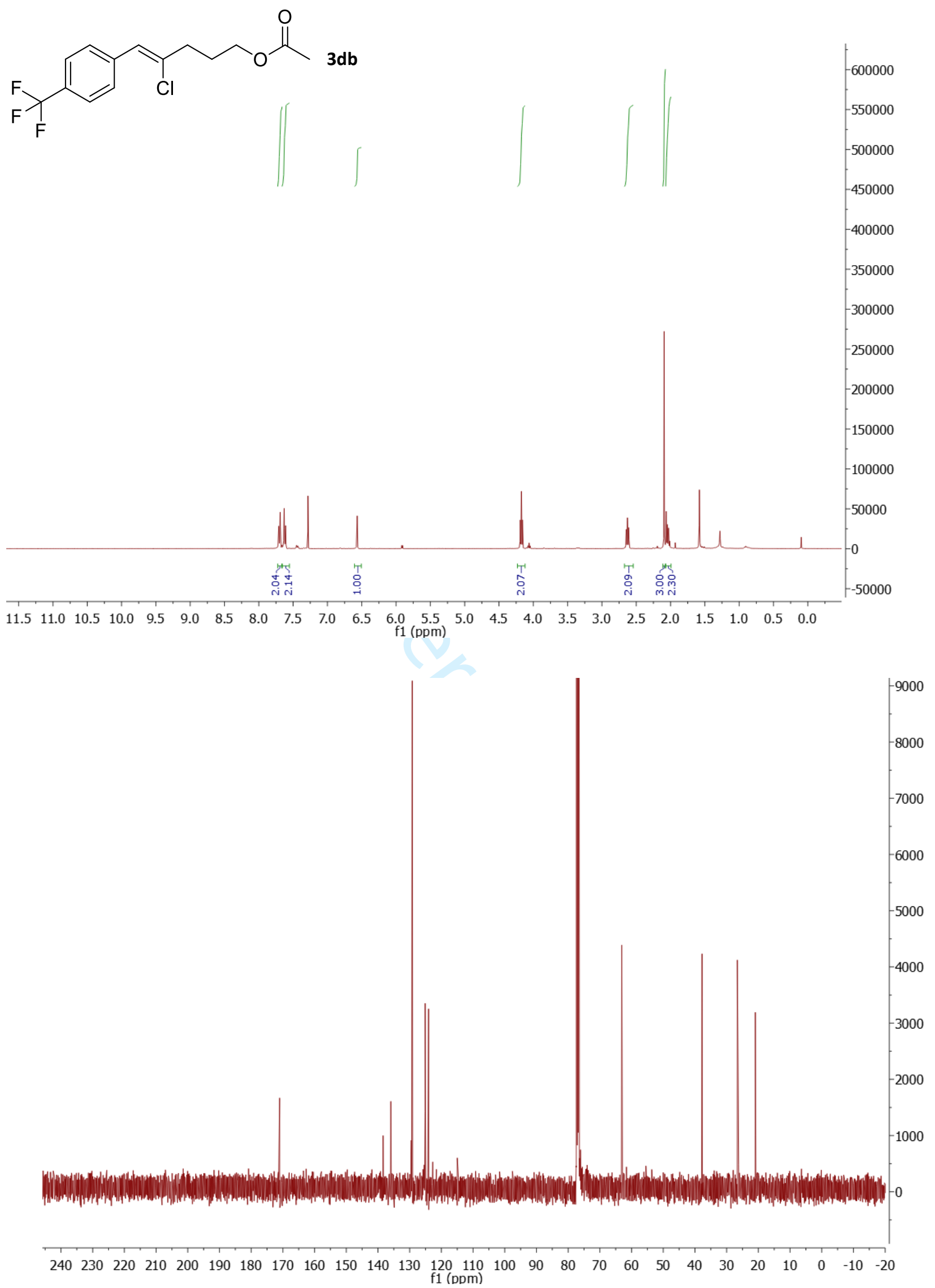


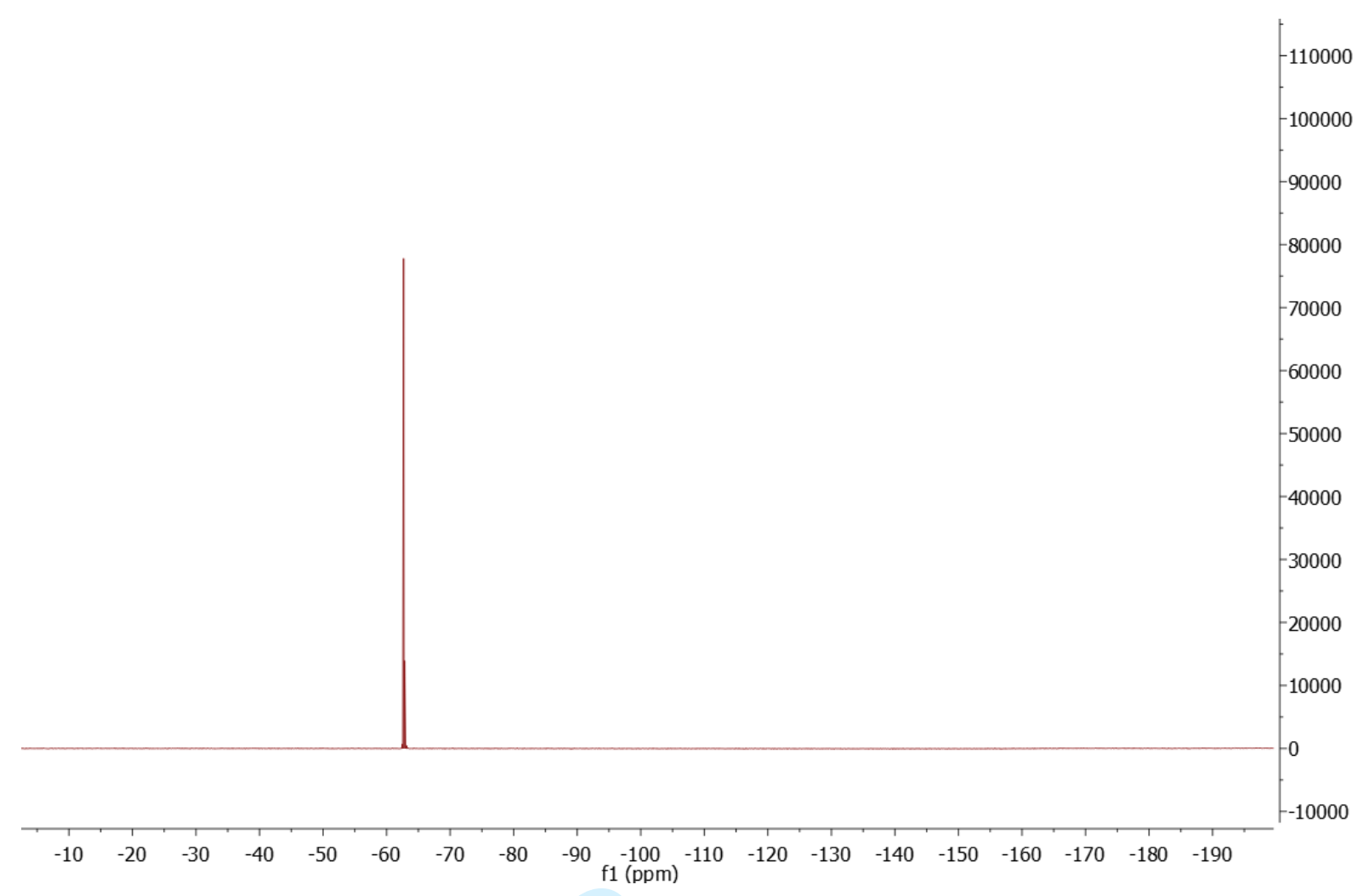


<smiles>CC(C)(C)O</smiles>

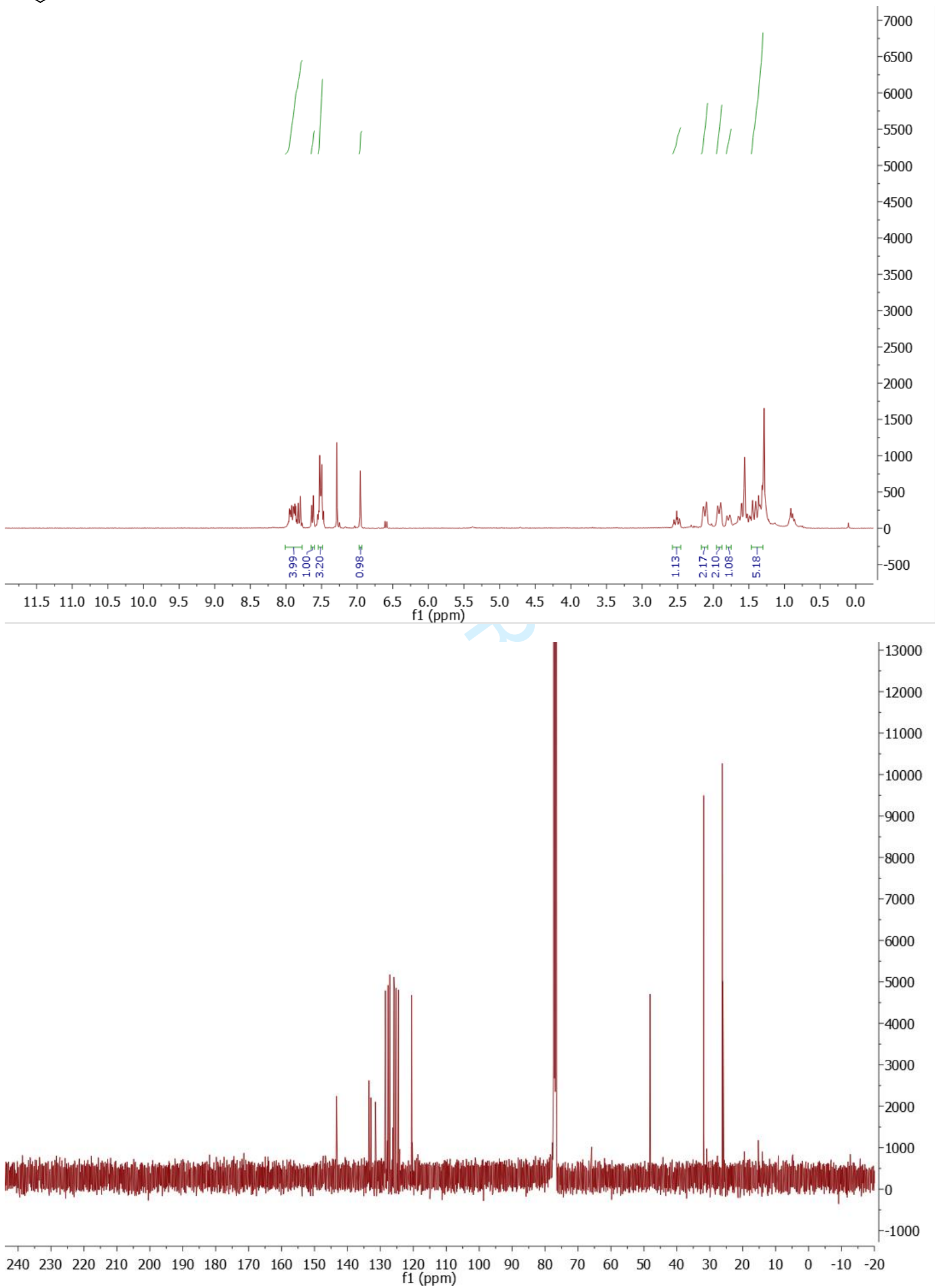


3bc
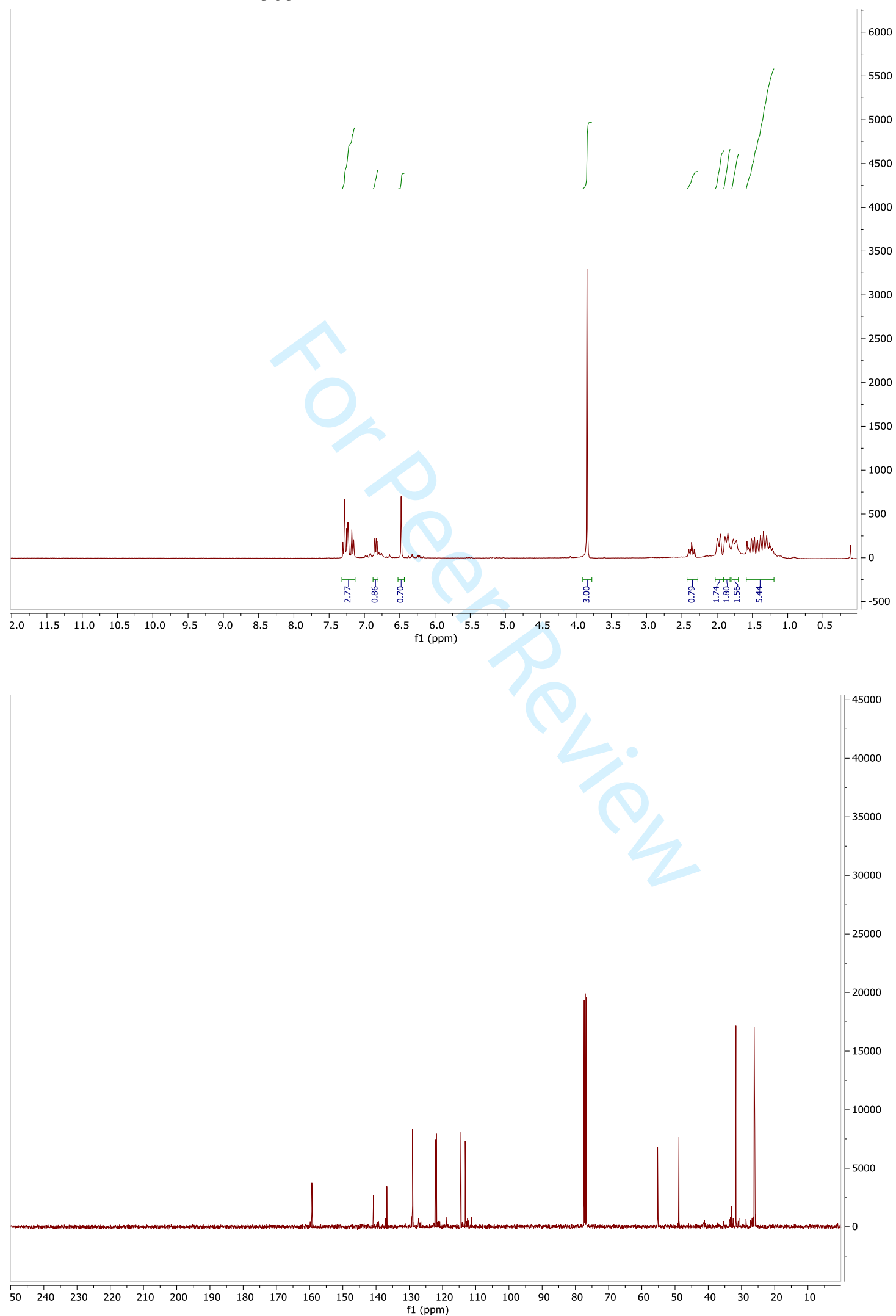
<smiles>CC(C)(C)C</smiles>

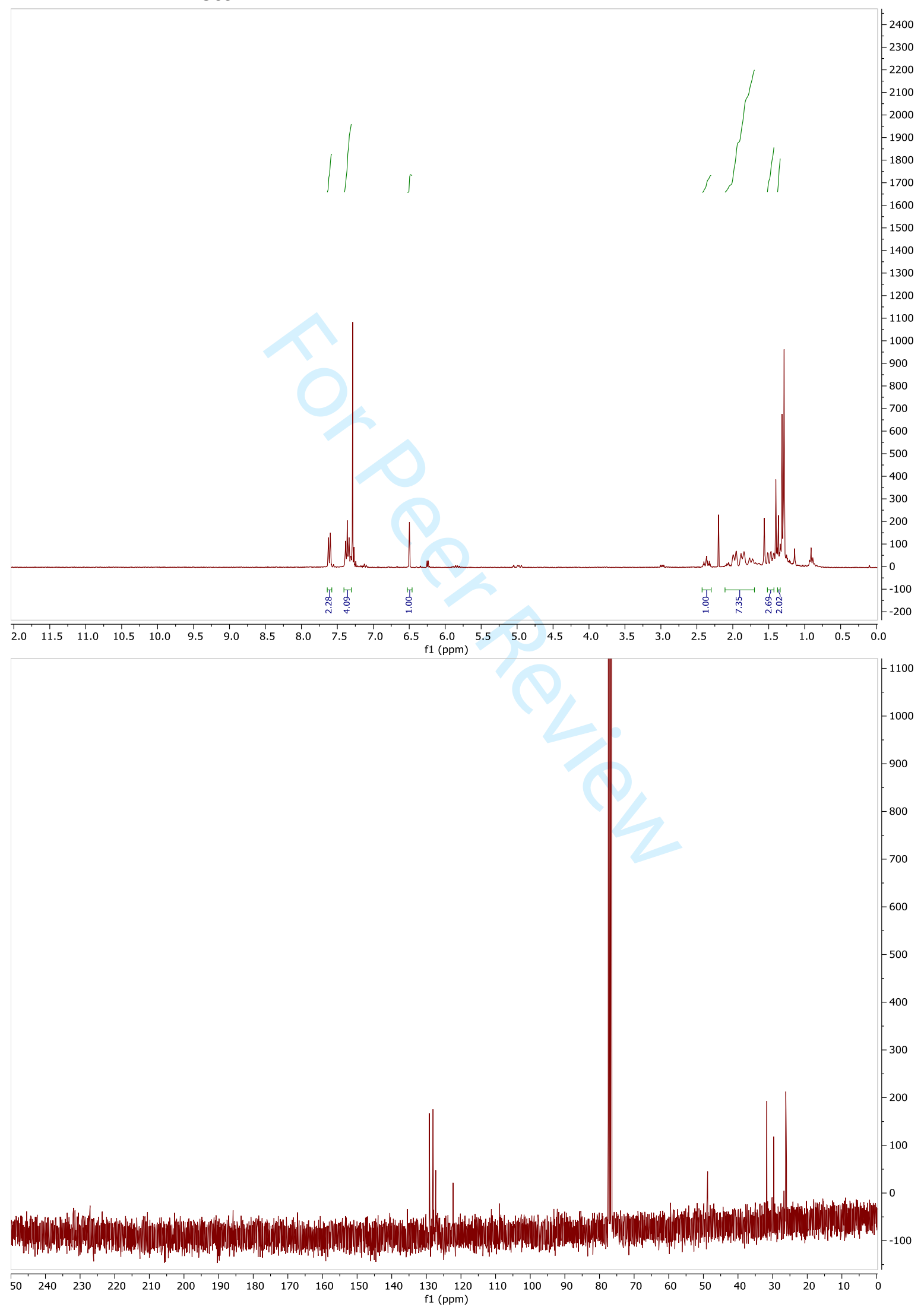


$\mathrm{N}_{\mathrm{Cl}}$
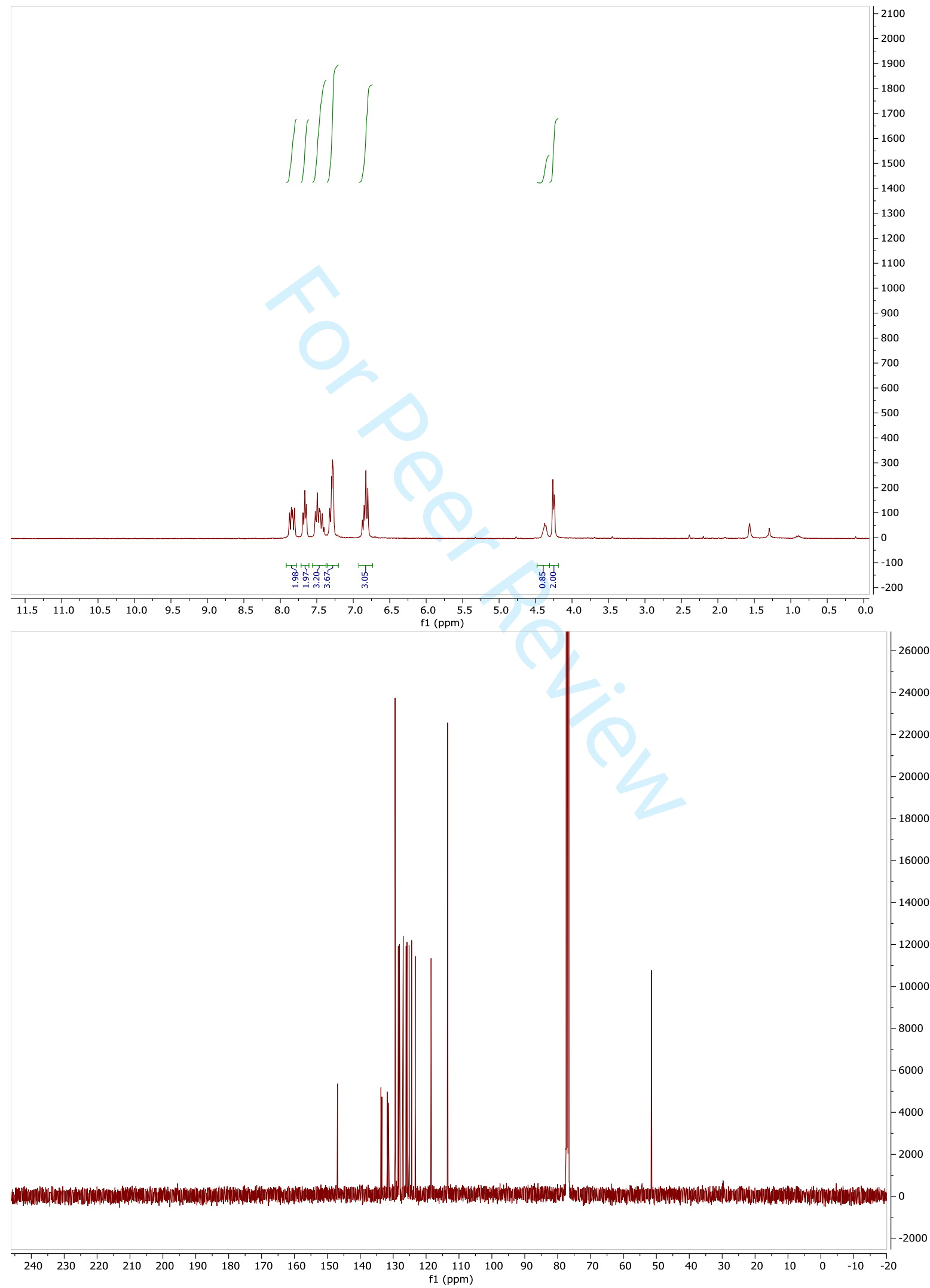
<smiles>COc1cccc(/C=C(\Cl)CNc2ccccc2)c1</smiles>

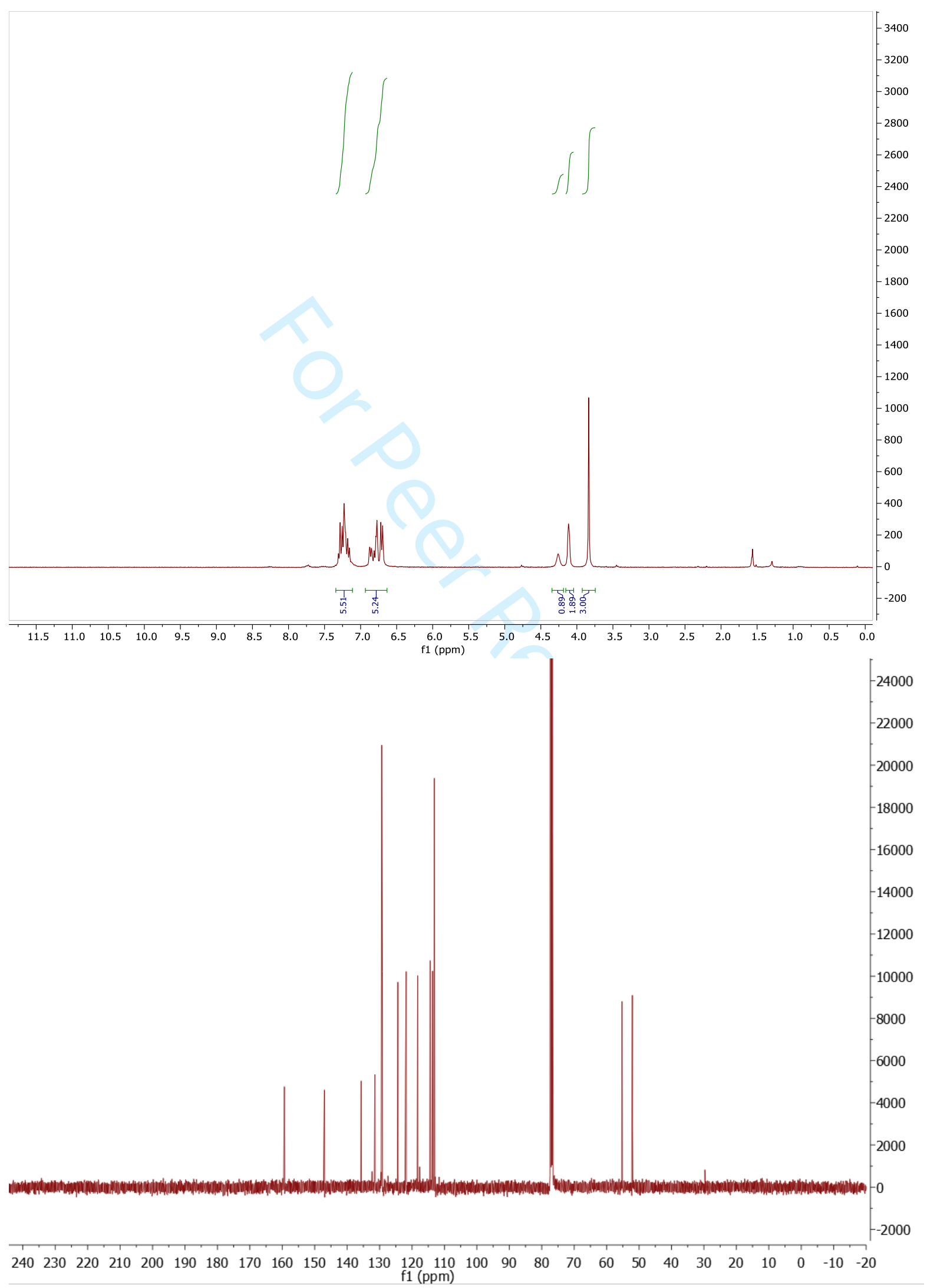


<smiles>FC(F)(F)c1ccc(/C=C(\Cl)CNc2ccccc2)cc1</smiles>

3dd
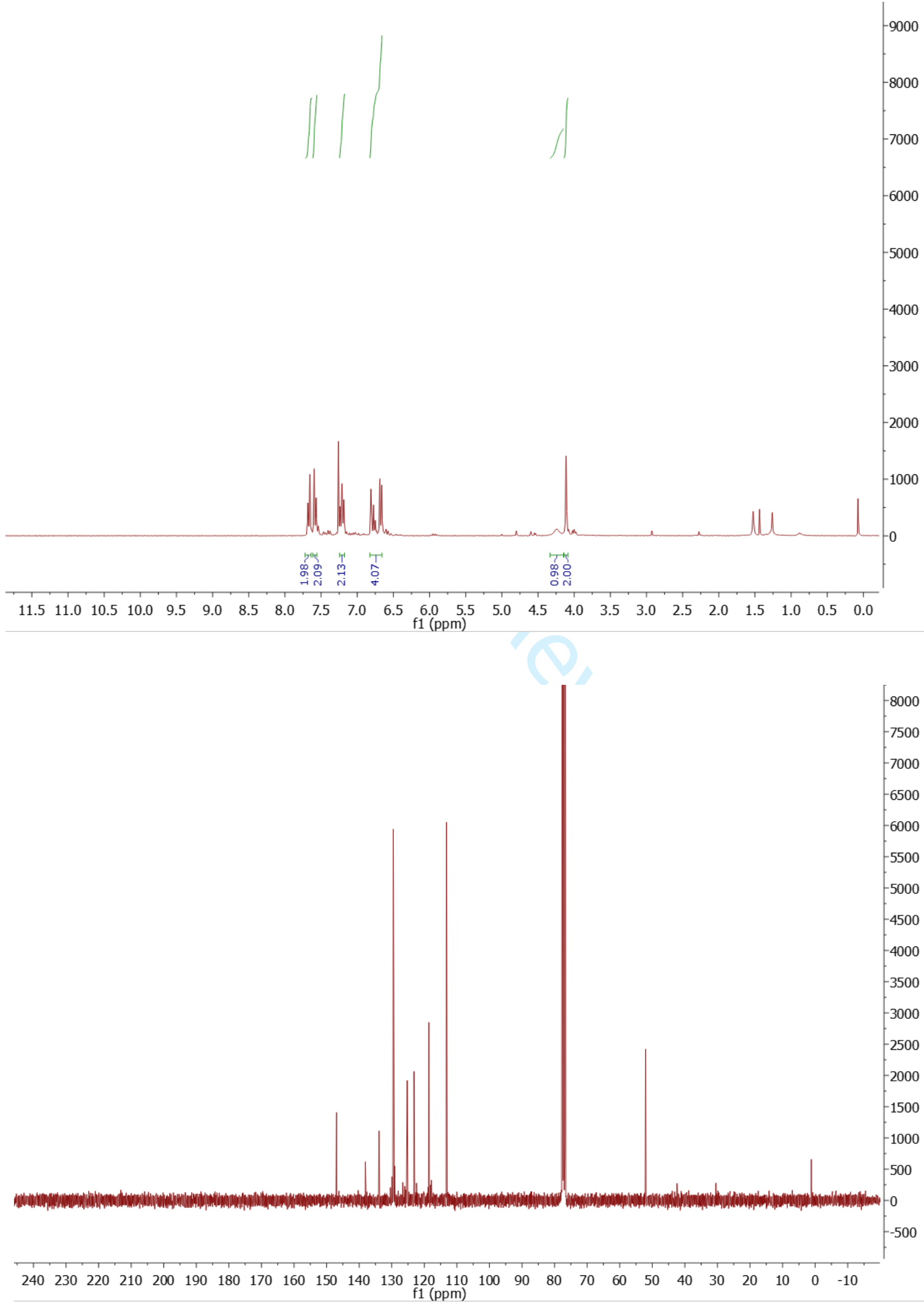


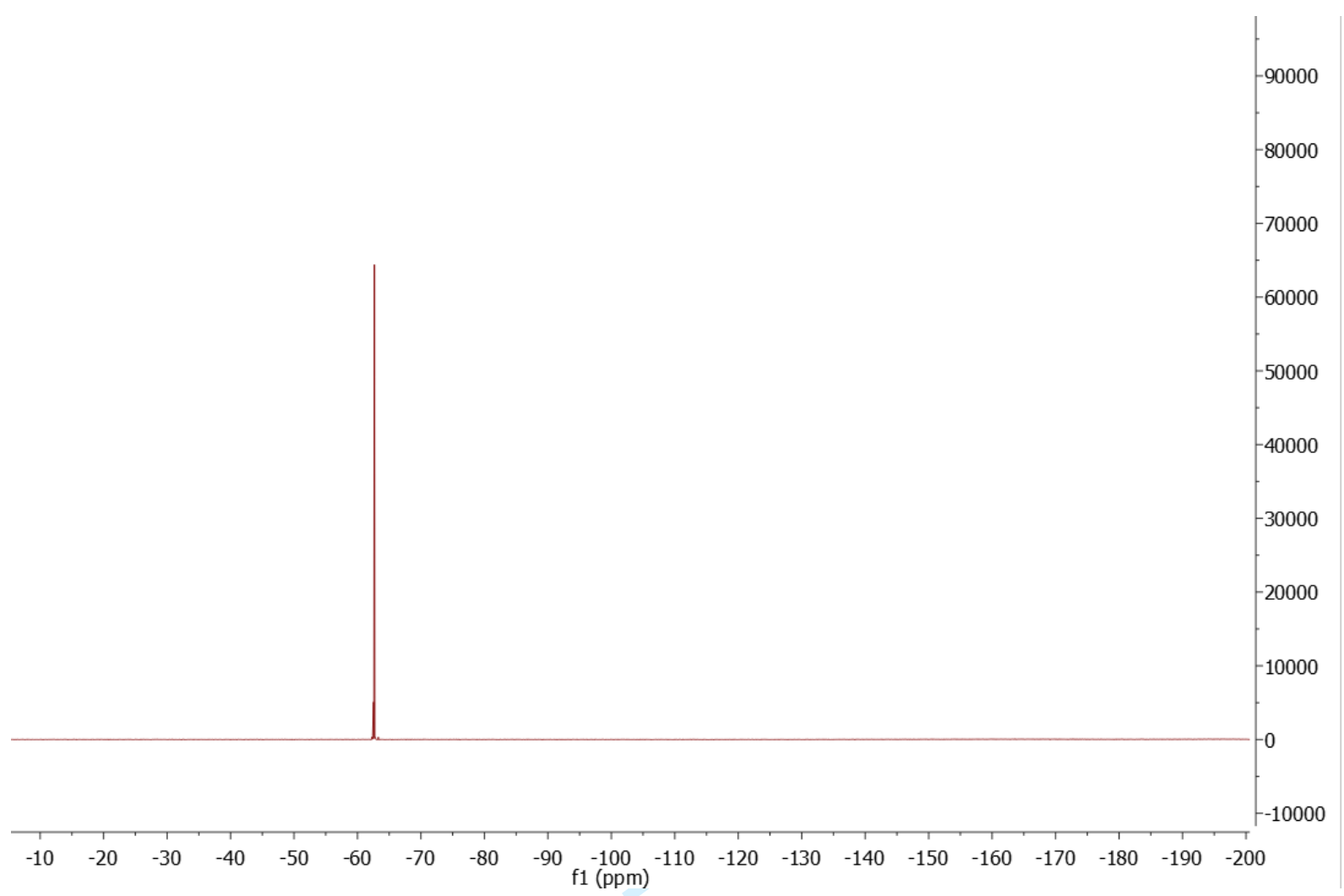




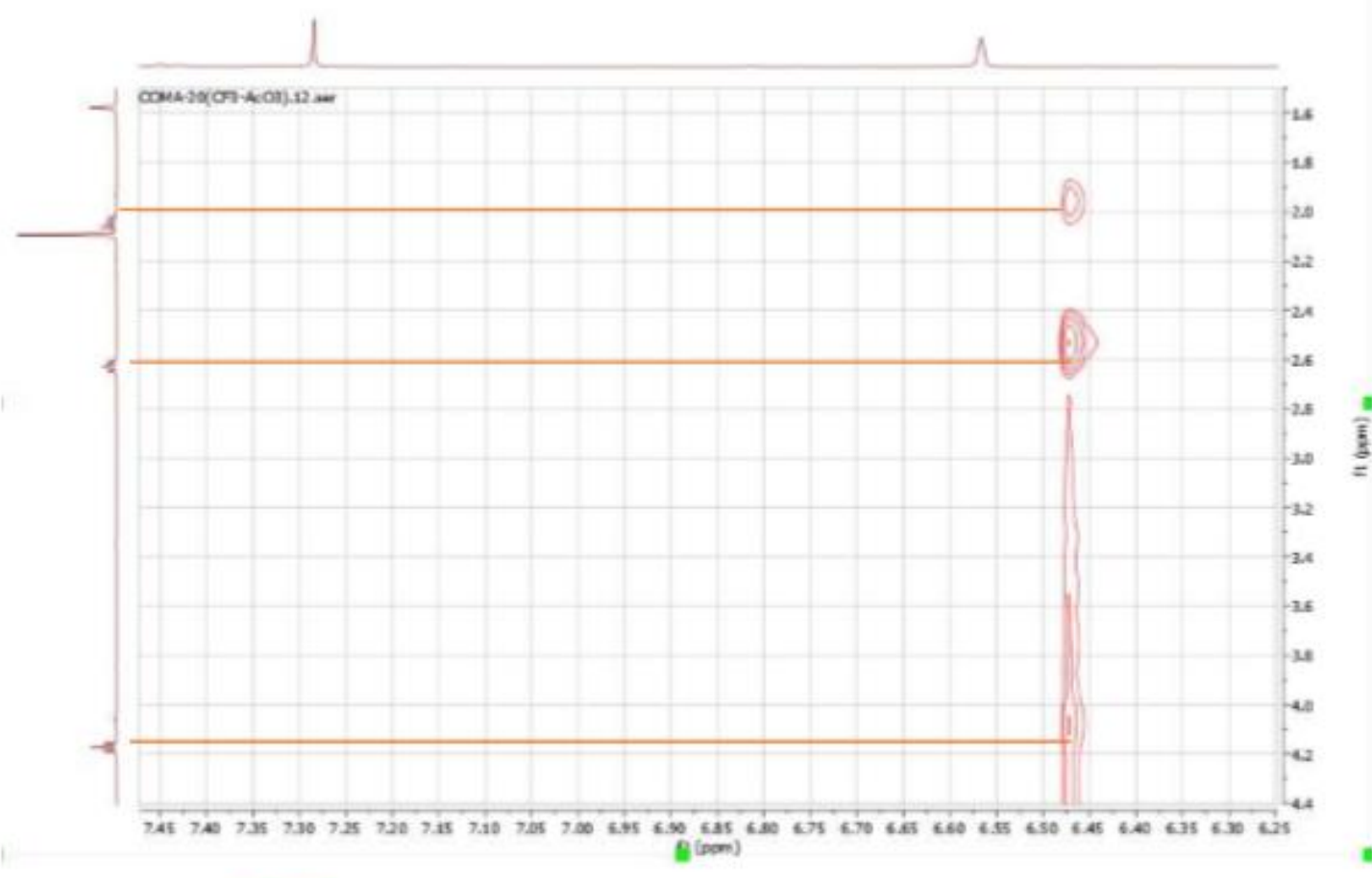

The red correlation spots show the remote space couplings between the vinylic proton and the alkyl ones which confirms the configuration of the double bond

NOESY experiments permitted to confirm the configuration of the double bonds of the cross-coupling products. We adopted for all the coupling products the same methodology as for the example here under: 


\section{X-ray crystallographic details}

The structures of $\mathbf{2 a - N a}$ and $\mathbf{2 c}-\mathbf{N a}$ were determined by X-ray.

A single crystal of 2a-Na was selected, mounted onto a cryoloop, and transferred in a cold nitrogen gas stream. Intensity data were collected with a BRUKER Kappa-APEXII diffractometer with graphite-monochromated Mo$K \alpha$ radiation. Data collection was performed with APEX2 suite (BRUKER). Unit-cell parameters refinement, integration and data reduction were carried out with SAINT program (BRUKER). SADABS (BRUKER) was used for scaling and numerical absorption corrections. The structure was solved using the Olex2 (Dolomanov et al., 2009) software package and refined by full-matrix least-squares methods using SHELXL-14 (Sheldrick, 2014).

A single crystal of 2c-Na was selected, mounted onto a cryoloop, and transferred in a cold nitrogen gas stream. Intensity data were collected with a BRUKER Kappa-APEXII diffractometer with micro-focused Cu-K $\alpha$ radiation. Data collections were performed with APEX3 suite (BRUKER). Unit-cell parameters refinement, integration and data reduction were carried out with SAINT program (BRUKER). SADABS (BRUKER) was used for scaling and multi-scan absorption corrections. The WinGX (Farrugia, 2012) suite of programs was used to solve the structure (cf cif files) and refined by full-matrix least-squares methods using SHELXL-15 (Sheldrick, 2015).

The figure 1 illustrates the polymeric unit of silicate $\mathbf{2 a - N a}$ and figure 2 the one for $\mathbf{2 c}-\mathbf{N a}$.

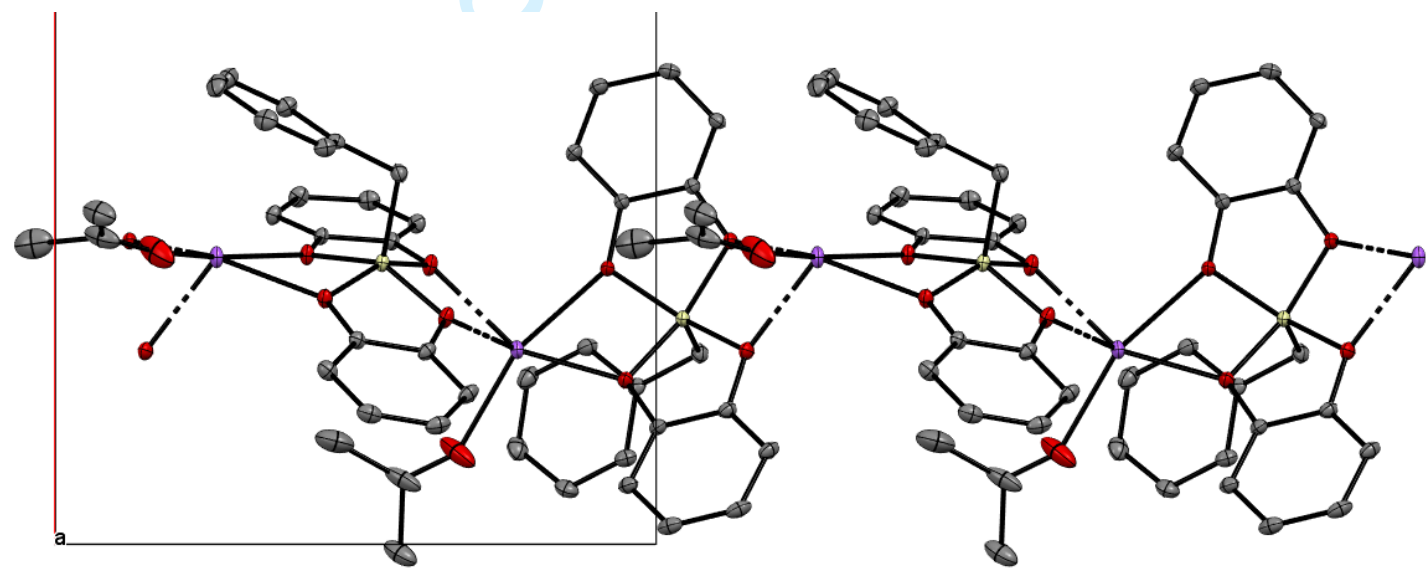

Figure 1. X-ray crystal packing of 2a-Na (view along the b-axis), thermal ellipsoids are drawn at $25 \%$ probability level. Hydrogen atoms are omitted for clarity. Dashed lines denote bonds between neighbouring silicates.

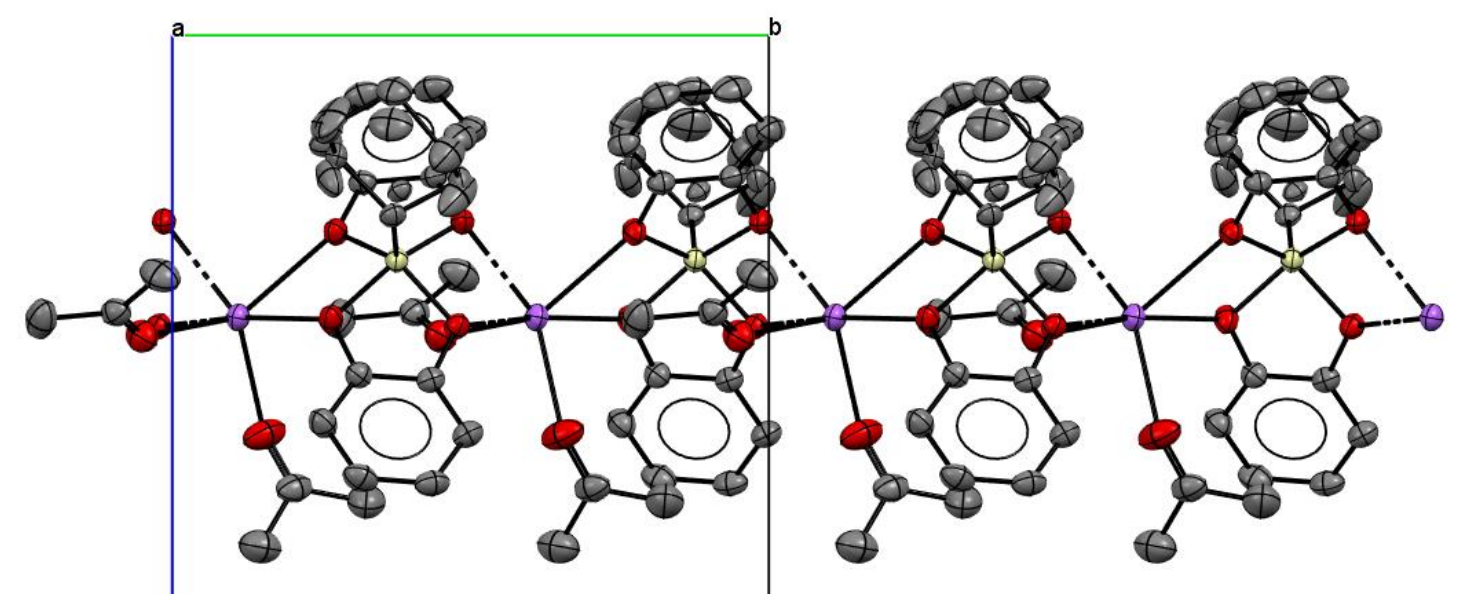

Figure 2. X-ray crystal packing of 2c-Na (view along the a-axis), thermal ellipsoids are drawn at 25\% probability level. Hydrogen atoms are omitted for clarity. Dashed lines denote bonds between neighbouring silicates.

Table 1 gives some crystal information for the structures $\mathbf{2 a - N a}$ and $\mathbf{2 c - N a}$. Other crystal and refinement information can be found in the CIF file of each structure, downloadable free of charge on www.ccdc.cam.ac.uk, with CCDC numbers 2058159 and 2050302 respectively. 
Table 1. Crystal information

\begin{tabular}{lcc}
\hline & 2a-Na & 2c-Na \\
\hline CCDC number & 2048159 & 2050302 \\
\hline Empirical formula & $\mathrm{C}_{22} \mathrm{H}_{21} \mathrm{NaO}{ }_{5} \mathrm{Si}$ & $\mathrm{C}_{24} \mathrm{H}_{31} \mathrm{NaO}_{6} \mathrm{Si}$ \\
\hline Temperature (K) & $200(2)$ & $200(1)$ \\
\hline Space group & $\mathrm{P} 42{ }_{1} \mathrm{C}$ & $\mathrm{Pbca}$ \\
\hline $\mathbf{a}(\AA)$ & $19.0046(7)$ & $20.1599(19)$ \\
\hline $\mathbf{b}(\AA)$ & $19.0046(7)$ & $11.4841(11)$ \\
\hline $\mathbf{c}(\AA)$ & $11.5788(5)$ & $21.738(3)$ \\
\hline $\boldsymbol{\alpha}\left({ }^{\circ}\right)$ & 90 & 90 \\
\hline $\boldsymbol{\beta}\left(^{\circ}\right)$ & 90 & 90 \\
\hline $\boldsymbol{\gamma}\left({ }^{\circ}\right)$ & 90 & 90 \\
\hline $\mathbf{Z}$ & 8 & 8 \\
\hline \hline
\end{tabular}




\section{Cyclic voltammetries}<smiles>c1ccc(C[Si-]23(Oc4ccccc4O2)Oc2ccccc2O3)cc1</smiles>

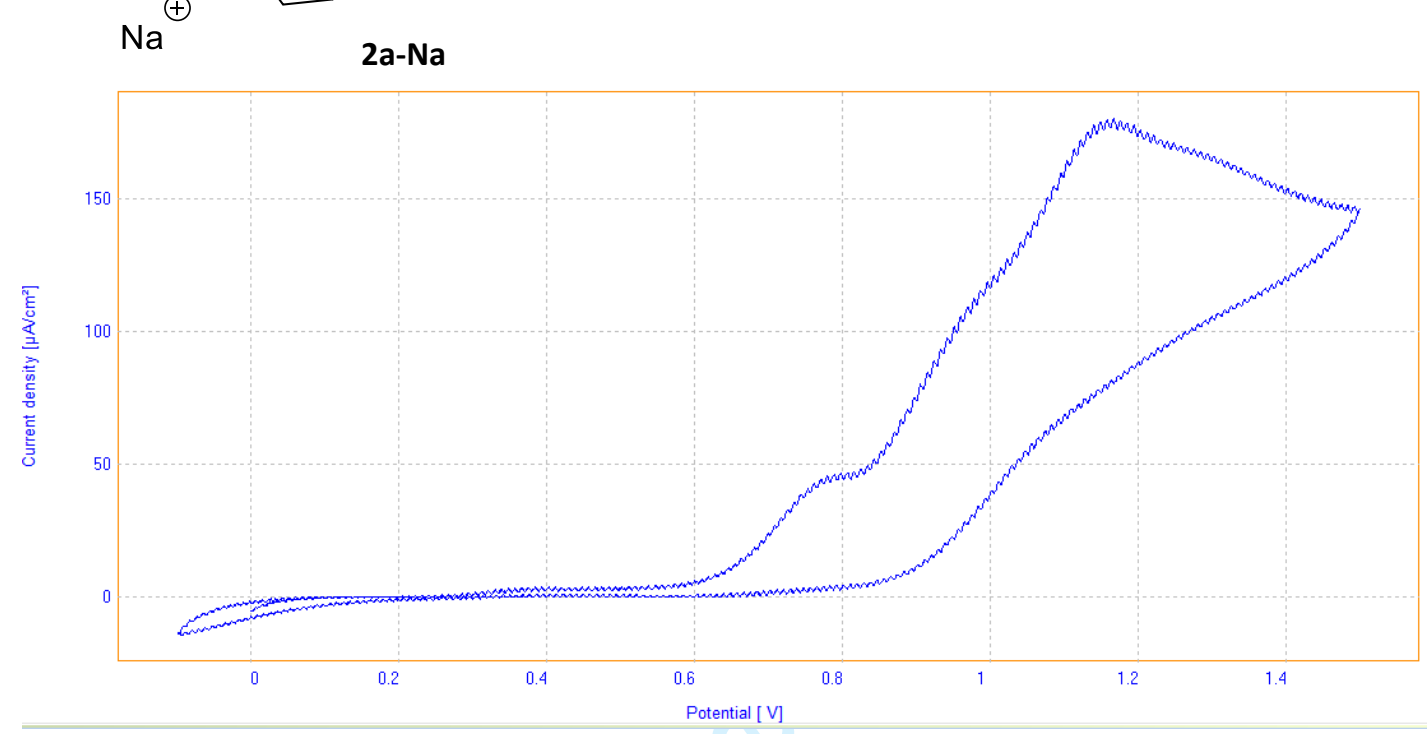

CV performed towards oxidative potentials of DMF solution (10 ml) containing $n-B_{4} \mathrm{NBF}_{4}(1 \mathrm{mmol})$ at room temperature, at a scan rate of $0.2 \mathrm{~V} \cdot \mathrm{s}^{-1}$ using steady glassy carbon disk electrode $(\mathrm{d}=3 \mathrm{~mm})$ as working electrode, a SCE as reference and Pt wire as counter-electrode. CV with 2a-Na $(0.1 \mathrm{mmol})$.<smiles>[Y]O[Si]1(Cc2ccccc2)Oc2ccccc2O1</smiles>

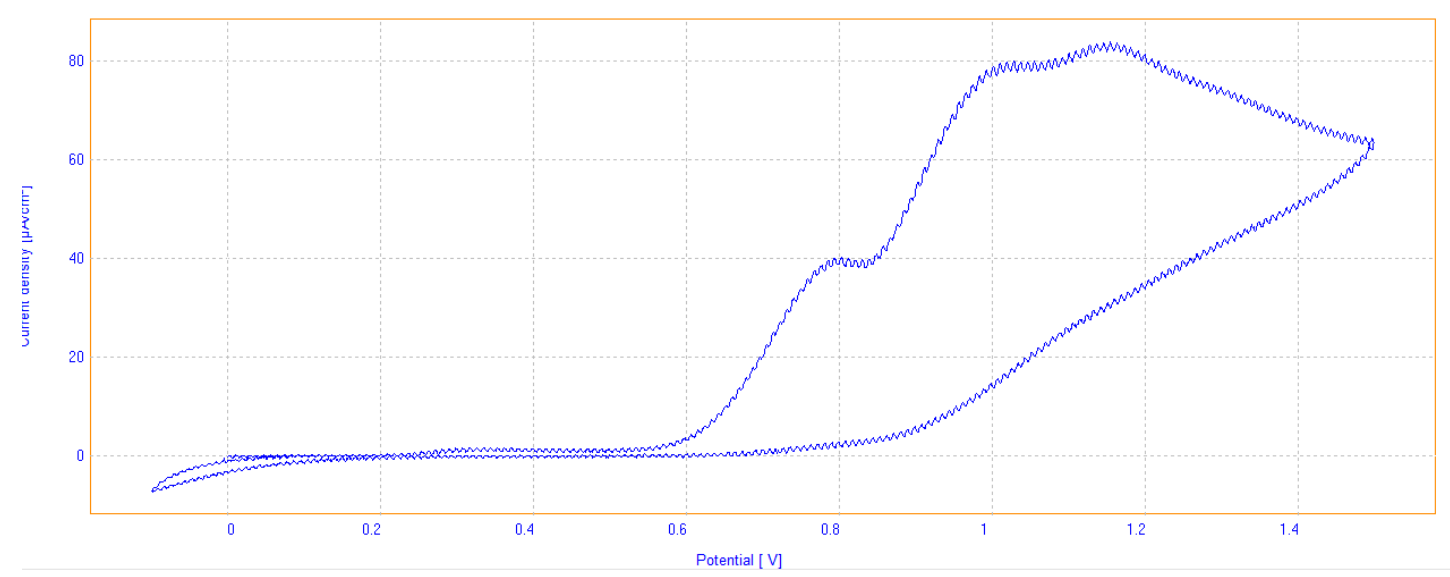

CV performed towards oxidative potentials of DMF solution $(10 \mathrm{ml})$ containing $\mathrm{n}-\mathrm{Bu}_{4} \mathrm{NBF}_{4}(1 \mathrm{mmol})$ at room temperature, at a scan rate of $0.2 \mathrm{~V} \cdot \mathrm{s}^{-1}$ using steady glassy carbon disk electrode $(\mathrm{d}=3 \mathrm{~mm})$ as working electrode, a SCE as reference and Pt wire as counter-electrode. CV with 2a-K (0.1 mmol) 
<smiles>O[Si](Oc1ccccc1)(Oc1ccccc1)Oc1ccccc1O[Si]1(O)OCCOCCOCCOc2ccccc2O1</smiles>

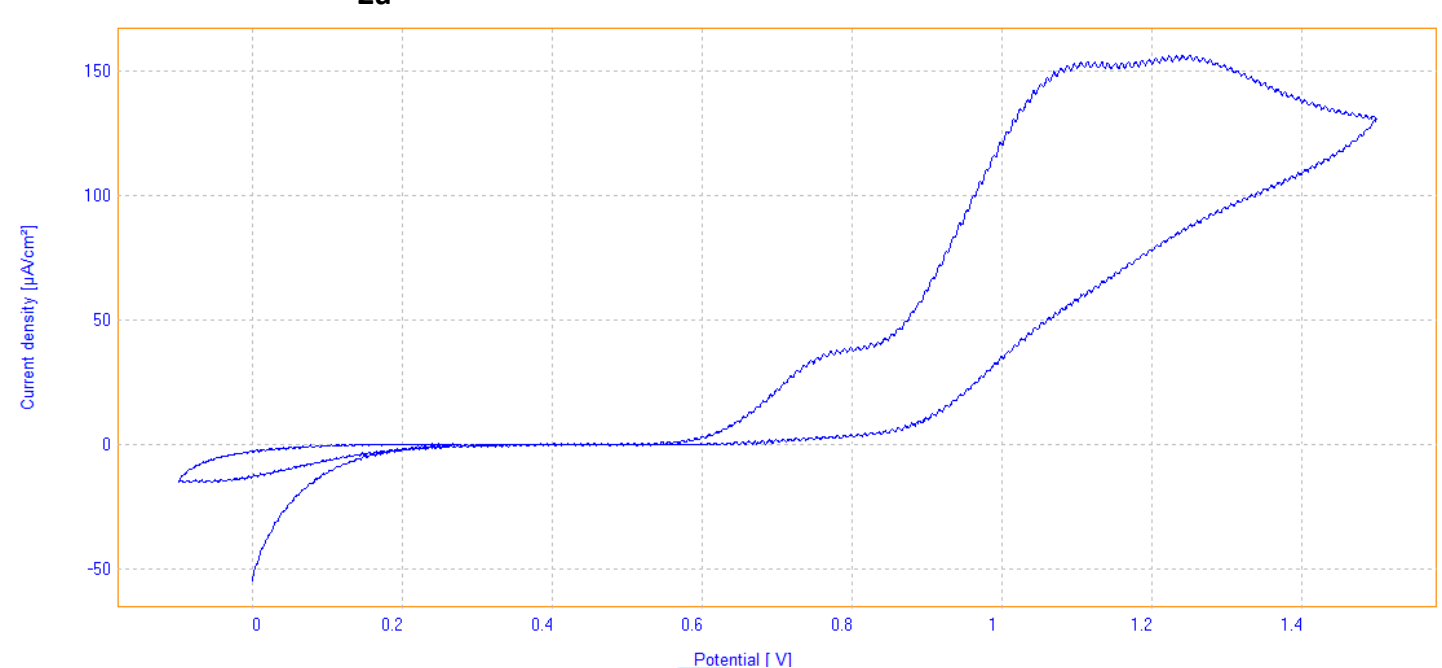

CV performed towards oxidative potentials of DMF solution (10 ml) containing $n-B_{4} \mathrm{NBF}_{4}(1 \mathrm{mmol})$ at room temperature, at a scan rate of $0.2 \mathrm{~V} \cdot \mathrm{s}^{-1}$ using steady glassy carbon disk electrode $(\mathrm{d}=3 \mathrm{~mm})$ as working electrode, a SCE as reference and Pt wire as counter-electrode. CV with $2 \mathrm{a}^{\prime}(0.1 \mathrm{mmol})$.<smiles>CC(=O)OCCC[Si]1(O)Oc2ccccc2O1</smiles>

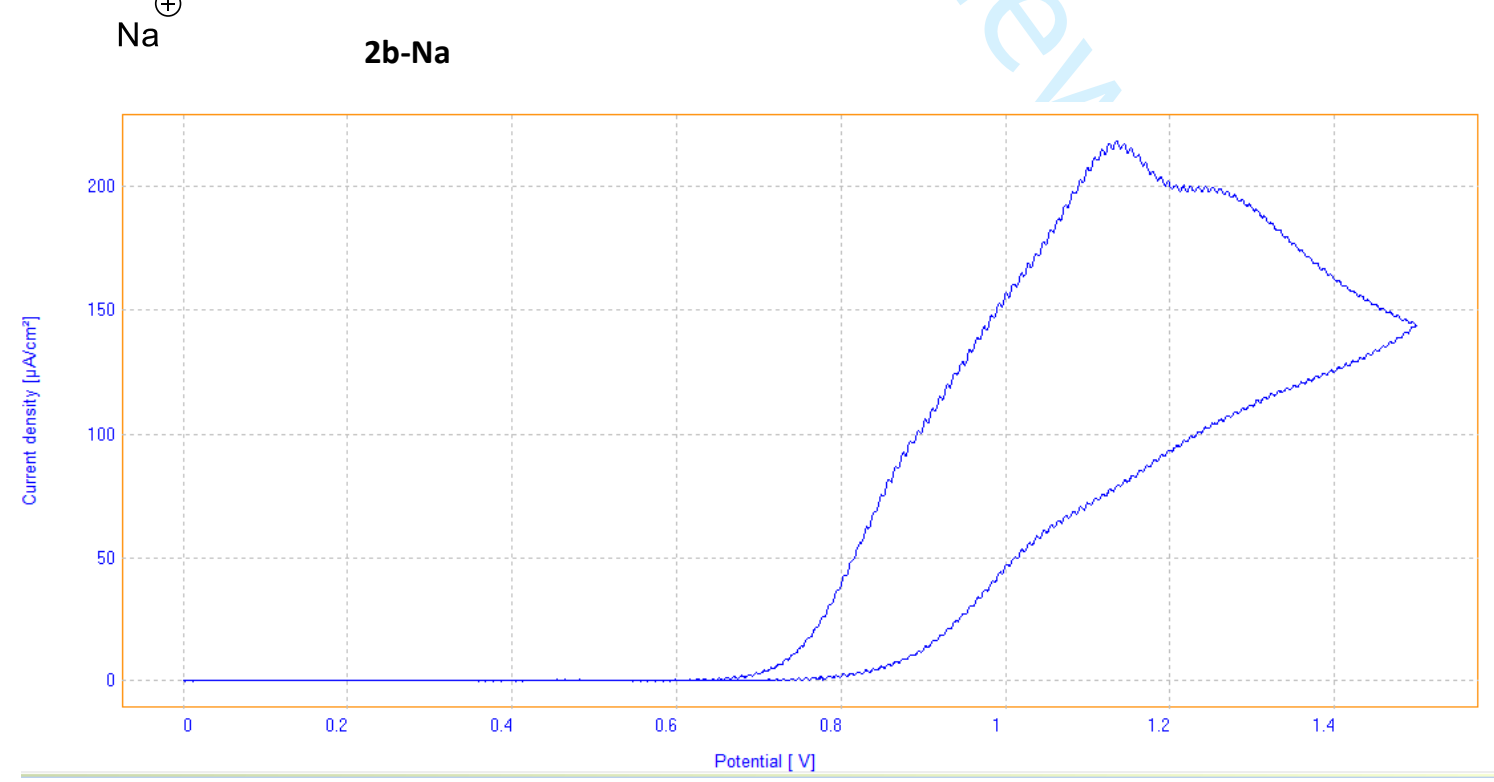

CV performed towards oxidative potentials of DMF solution (10 ml) containing $n-B_{4} \mathrm{NBF}_{4}(1 \mathrm{mmol})$ at room temperature, at a scan rate of $0.2 \mathrm{~V} \cdot \mathrm{s}^{-1}$ using steady glassy carbon disk electrode $(\mathrm{d}=3 \mathrm{~mm})$ as working electrode, a SCE as reference and Pt wire as counter-electrode. CV with $\mathbf{2 b - N a}(0.1 \mathrm{mmol})$. 


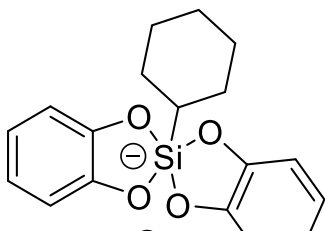

$\oplus$

$2 \mathrm{c}-\mathrm{Na}$

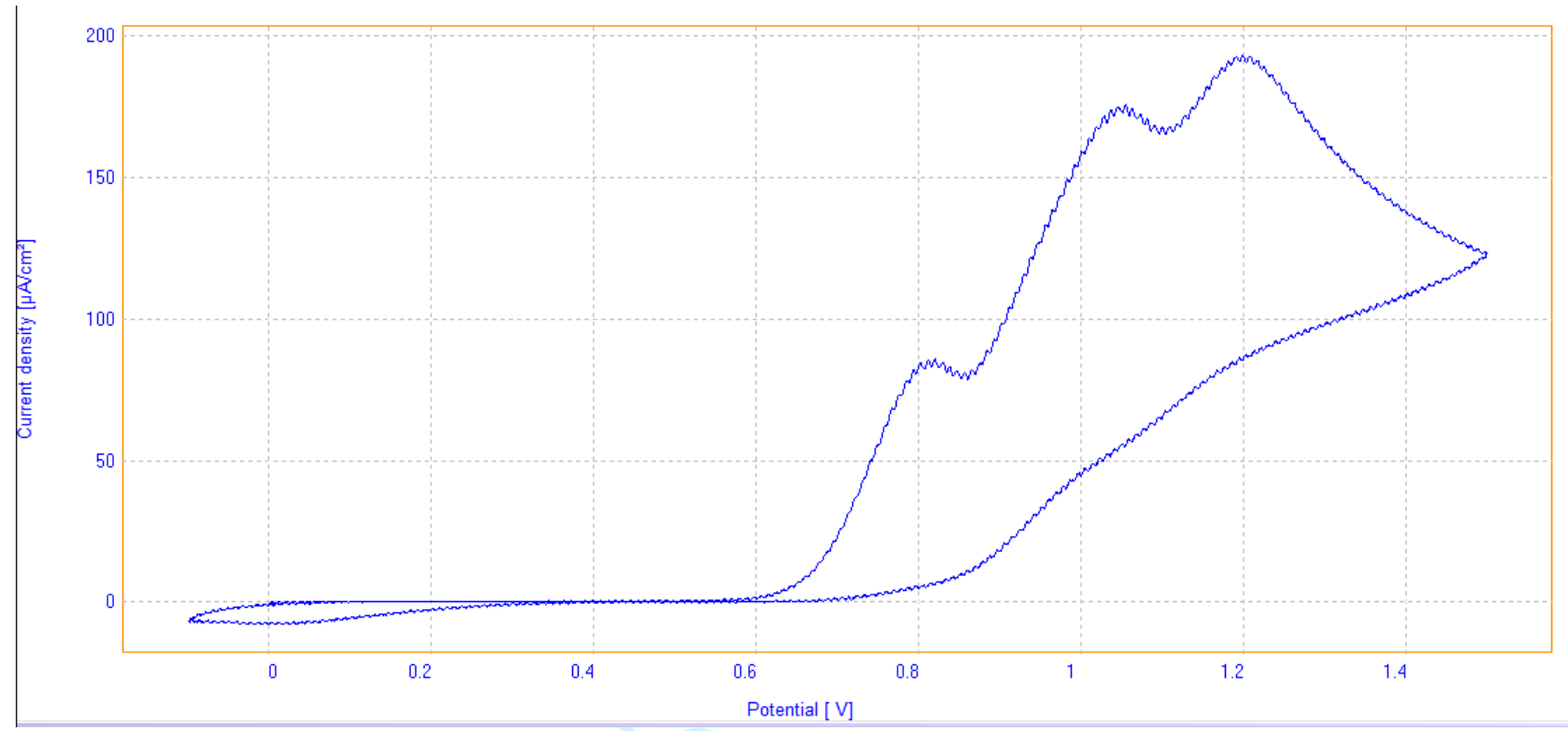

$\mathrm{CV}$ performed towards oxidative potentials of DMF solution $(10 \mathrm{ml})$ containing $\mathrm{n}-\mathrm{Bu}_{4} \mathrm{NBF}_{4}(1 \mathrm{mmol})$ at room temperature, at a scan rate of $0.2 \mathrm{~V} \cdot \mathrm{s}^{-1}$ using steady glassy carbon disk electrode $(\mathrm{d}=3 \mathrm{~mm})$ as working electrode, a SCE as reference and Pt wire as counter-electrode. CV with $\mathbf{2 c - N a ~}(0.1 \mathrm{mmol})$. 